\title{
COMMENTS
}

\section{The Emerging Constitutional Jurisprudence of Justice Stevens}

TABLE OF CONTENTS

I. Regulation of Offensive SPEech $\ldots \ldots \ldots \ldots \ldots, 158$

A. Development of Obscenity Doctrine ......... 158

B. Regulation of "Less Protected" Speech:

The Importance of Context . . . . . . . . . . 161

Smith v. United States

Young v. American Mini-Theatres, Inc.

FCC v. Pacifica Foundation

C. Implications for First Amendment Doctrine ... 166

II. The Establishment Clause . . . . . . . . . . . 171

Roemer v. Board of Public Works

Wolman $v$. Walter

III. ProteCtion From Government SEARChes. . . . . . . . 174

A. Reasonable Searches and the Warrant

Requirement

Marshall v. Barlow's, Inc.

Michigan v. Tyler

B. The Requirement of Probable Cause:

Third-Party Searches .................. 183

Zurcher v. Stanford Daily

C. Justice Stevens and the Dilemma of Fourth

Amendment Doctrine . . . . . . . . . . . . . . 187

IV. Procedural Due Process . . . . . . . . . . . . . 189

A. Due Process and Capital Punishment:

Justice Steven's Protected Interest Analysis . . . 190 Gardner v. Florida

B. Restriction of the Scope of Procedural Due

Process ................................ 194

1. Protected Interests . . . . . . . . . . . . . . 194

Bishop v. Wood

Codd v. Velger

2. Adequacy of Process ................ 196

Memphis Light, Gas \& Water Division v. Craft

C. Expansive Due Process Protection for

Deprivations of Liberty ............... 200

Ingraham v. Wright 
Meachum v. Fano

Moody v. Daggett

D. Justice Stevens's Unique Approach to

Procedural Due Process . . . . . . . . . . . . . 204

V. Equal Protection .................. 206

A. Justice Stevens and Two-Tier Analysis . . . . 206 Mathews v. Lucas

Craig v. Boren

B. The Search for a Single Standard:

Three "Explanations" ................ 210

Craig v. Boren

Califano v. Jobst

Zablocki v. Redhail

C. A Standard for All Cases, or a Standard for Each? 213

VI. Due Process of Lawmaking . . . . . . . . . . 217

A. The Requirement of Rational Decisionmaking . 219

1. Questionable Classifications:

Searching for Legislative Purpose . . . . . . $\quad 219$

Hampton v. Mow Sun Wong

Califano $v$. Goldfarb

Craig v. Boren

2. The Requirement of an Articulated Purpose . . 223

Delaware Tribal Business Committee v. Weeks . . .

B. The Proper Decisionmaker ............. 226

Hampton v. Mow Sun Wong

City of Eastlake v. Forest City Enterprises, Inc.

C. The Scope of Due Process of Lawmaking. . . . . . 230

VII. Conclusion $\ldots \ldots \ldots \ldots \ldots \ldots \ldots \ldots \ldots \ldots \ldots . \ldots \ldots 2$ 


\section{The Emerging Constitutional Jurisprudence of Justice Stevens}

Since Justice John Paul Stevens joined the Supreme Court in the fall of 1975, his course has defied classification. Some observers have detected a movement into the "liberal bloc" of the Court, generally viewed as consisting of Justices Brennan and Marshall. ${ }^{1}$ Yet he has appeared as the "conservative" standard-bearer in several cases of particular importance. ${ }^{2}$ In the uncertain decisionmaking of the divided Burger Court, Justice Stevens has assumed a position of importance by avoiding adherence to the views of either of the identifiable wings of the Court.

This comment does not attempt to identify a definitive judicial world-view held by Justice Stevens. His tenure on the Court has been too brief, and his positions too complex, to make such a generalization possible. Nor does the comment analyze all of the Justice's written opinions ${ }^{3}$ or the totality of his voting record. ${ }^{4}$ Rather, the scope of our endeavor is more modest: we examine a sample of Justice Stevens's opinions on constitutional issues, identify those areas in which his jurisprudence is distinctive, and suggest certain recurring themes in his constitutional thinking.

The comment begins with an examination of Justice Stevens's contributions to the particular problems of regulation of offensive speech, state aid to religion, and fourth amendment protection against administrative and third-party searches. The focus then shifts to an analysis of the Justice's opinions on the fifth and fourteenth amendment guarantees of procedural due process and equal protection. Next, the comment examines the Justice's developing concern with the rationality of the legislative process-the "due process of lawmaking." In each of these relatively independent sections, we offer some observations on the Justice's decisionmaking process and attempt to place his approach in perspective with the

' See, e.g., B. Fein, Significant Decisions of The Supreme Court, 1976-77 Term 13 (1978). Cf. Ball \& Uhlman, Justice John Paul Stevens: An Initial Assessment, 1978 B.Y.L. REv. 567, 581 (concluding that Justice Stevens must be characterized as a centrist).

2 See, e.g., Regents of the Univ. of Cal. v. Bakke, 98 S.Ct. 2733 (1978); FCC v. Pacifica Foundation, 98 S.Ct. 3026 (1978).

S Since his arrival on the Court, Justice Stevens has written more opinions than any other Justice, See The Supreme Court, 1977 Term, 92 HaRv. L. REv. 1, 327 (1978); The Supreme Court, 1976 Term, 91 HARv. L. Rev. 1, 295 (1977); The Supreme Court, 1975 Term, 90 HaRv. L. Rzv. 1, 276 (1976).

The voting records of each Justice are compiled yearly in the November issue of the Harvard Law Review. See, e.g., The Supreme Court, 1977 Term, supra note 3, at 327-30. 
current doctrine of the Burger Court. Finally, the comment draws some generalizations from the Justice's constitutional analysis and offers an evaluation of his emerging jurisprudence.

\section{Regulation of Offensive Speech}

Few areas of constitutional adjudication have so divided and perplexed the Supreme Court and legal commentators as has the accommodation of the first amendment's protection of freedom of speech to the regulation of obscenity ${ }^{5}$ and, more recently, sexrelated speech falling short of the obscene. ${ }^{b}$ At no time in recent history has the Court reached a wide consensus on these issues. In his brief tenure on the Court, Justice Stevens has outlined a position that departs significantly from the views of his fellow Justices. In order to understand this departure, it is necessary to review the recent history of Supreme Court decisions regarding obscenity.

\section{A. Development of Obscenity Doctrine}

The history of the Court's recent obscenity doctrine begins with Roth $v$. United States. ${ }^{7}$ In his majority opinion in Roth, Justice Brennan argued that obscenity is "utterly without redeeming social importance"8 and for that reason not within the range of speech the first amendment protects. The resulting distinction between protected and unprotected speech-which was to dominate the Court's thinking until the appointment of Justice Stevens-eliminated any question regarding the status of obscene speech: it was unprotected and could be regulated. ${ }^{9}$ Yet the Court's distinction left the potentially more intractable problem of defining "obscenity". ${ }^{10}$ Roth of-

5 "No other aspect of the First Amendment has, in recent years, demanded so substantial a commitment of our time, generated such disharmony of views, and remained so resistant to the formulation of stable and manageable standards." Paris Adult Theatre I v. Slaton, 413 U.S. 49, 73 (1973) (Brennan, J., dissenting). See also Interstate Circuit, Inc. v. City of Dallas, 390 U.S. 676, 704-05 (1968) (Harlan, J., concurring in part, dissenting in part).

- See FCC v. Pacifica Foundation, 98 S.Ct. 3026 (1978); Young v. American MiniTheatres, Inc., 427 U.S. 50 (1976).

7354 U.S. 476 (1957).

Id. at 484 .

- Once a given item was adjudged "obscene," its dissemination could be enjoined, e.g., McKinney v. Alabama, 424 U.S. 669 (1976), its distributor could be jailed, e.g., Ginzburg v. United States, 383 U.S. 463 (1966), and all copies could be destroyed, e.g., Kingsley Books, Inc. v. Brown, 354 U.S. 436, 444 (1957).

1 Not all members of the Court during that period considered the definition of obscenity dispositive. Justices Douglas and Black believed the government powerless to regulate even obscene speech. See United States v. Thirty-Seven Photographs, 402 U.S. 363, 379-80 (1971) (Black, J., joined by Douglas, J., dissenting); Ginzburg v. United States, 383 U.S. 463, 49192 (1966) (Black \& Douglas, JJ., dissenting); Jacobellis v. Ohio, 378 U.S. 184, 196 (1964) 
fered the first of many formulations of the proper test: "[w]hether to the average person, applying contemporary community standards, the dominant theme of the material taken as a whole appeals to prurient interest." Nine years later, Justice Brennan, writing in A Book Named "John Cleland's Memoirs of a Woman of Pleasure" v. Attorney General, ${ }^{12}$ propounded a more stringent test: "(a) the dominant theme of the material taken as a whole appeals to a prurient interest in sex; (b) the material is patently offensive because it affronts contemporary community standards relating to the description or representation of sexual matters; and (c) the material is utterly without redeeming social value."13

The fragile consensus achieved by the "Memoirs test" was short-lived. For a period of six years, ${ }^{14}$ in which at least thirty-one obscenity cases reached the Court, ${ }^{15}$ majority support could not be found on the Court for any one definition, and all decisions were made summarily after inspection of the materials by the Justices. ${ }^{16}$ During this period the Court acted as an "unreviewable board of censorship," 17 relying on subjective judgment and providing no guidance for future decisions. By 1973, virtually all members of the Court had lost faith in their ability to articulate any workable test for obscenity. Three members of the Court, led by Justice Brennan, ${ }^{18}$ decided that the Court was "manifestly unable" to define

(Black, J., joined by Douglas, J., dissenting).

Justice Harlan believed that the federal government is limited to regulating "hardcore pornography," but that the states may regulate "any material which, taken as a whole, has been reasonably found in state judicial proceedings to treat with sex in a fundamentally offensive manner, under rationally established criteria for judging such material." Jacobellis v. Ohio, 378 U.S. 184, 204 (1964) (Harlan, J., dissenting).

it 354 U.S. at 489 (citing cases).

12383 U.S. 413 (1966). Only Chief Justice Warren and Justice Fortas joined Justice Brennan in the plurality opinion. Justices Black, Douglas, and Stewart concurred on broader grounds; the plurality's test therefore governed the later disposition of obscenity cases. The principal distinction between the Roth and Memoirs tests was that the lack of "redeeming social value" shifted from being a justification for regulating obscenity under Roth to an element of the definition of obscenity under Memoirs. See L. Tribe, American ConstituTIONAL LAW $\$ 12-16$, at 661 (1978).

${ }^{13} 383$ U.S. at 418.

" This period, from 1967 to 1973, began with Redrup v. New York, 386 U.S. 767 (1967), and ended with the new standards in Miller v. California, 413 U.S. 15 (1973).

is The cases are collected in Paris Adult Theatre I v. Slaton, 413 U.S. 49,82 n.8 (1973) (Brennan, J., dissenting).

" If a majority agreed with the court of appeals that the material was obscene, it would deny certiorari. If it disagreed, it would grant certiorari and summarily reverse.

${ }_{17}$ Miller v. California, 413 U.S. 15, 22 n.3 (1973).

18 Justice Brennan had authored the Roth and Memoirs tests. In his change of mind, he was joined by Justices Stewart and Marshall. The position taken by these three Justices has remained constant in the five years since Miller. They have since consistently dissented from affirmances of criminal obscenity convictions, see, e.g., Smith v. United States, 431 U.S. 291, 
obscenity "except by reference to concepts so elusive that they fail to distinguish clearly between protected and unprotected speech."19 They concluded that the Court must abandon all attempts to regulate obscenity beyond those seeking to protect juveniles and nonconsenting adults. ${ }^{20}$ These three Justices thus moved closer to the stance of Justice Douglas, who steadfastly maintained his view that the first amendment prohibits any regulation of obscenity at all. ${ }^{21}$

A new majority of five was, however, able to coalesce around a single view in Miller $v$. California. ${ }^{22}$ The Court defined obscenity in a manner similar to the Memoirs test, but eliminated the requirement that the material be "utterly without redeeming social value." ${ }^{23}$ More significant than the definition was the new approach to adjudication under this standard: the determination of obscenity would be made on the basis of individual community standards, as decided by juries. The Court described as "essentially questions of fact" 24 the juries' determinations regarding prurient interest and patent offensiveness. It noted that "our Nation is simply too big and too diverse for this Court to reasonably expect that such standards could be articulated for all 50 states in a single formulation, even assuming the prerequisite consensus exists." 25 The majority's answer to the apparent impracticability of defining "obscenity" was thus to relinquish primary control of the definition to juries in the fifty states. Although community variations are not without limits, ${ }^{26}$

310 (1977) (Brennan, J., dissenting), joined or concurred in reversals of such convictions, see, e.g., Ballew v. Georgia, 435 U.S. 223, 246 (1978) (Brennan, J., concurring), and dissented from denials of certiorari in cases involving criminal obscenity convictions, see, e.g., Millican v. Unites States, 418 U.S. 947, 947 (Brennan, J., dissenting).

" Paris Adult Theatre I v. Slaton, 413 U.S. 49, 84 (1973) (Brennan, J., dissenting).

20 Justice Brennan carefully limited his conclusion to cases not involving minors or "obtrusive exposure to unconsenting adults." See id. at 113.

${ }^{21}$ Paris Adult Theatre I v. Slaton, 413 U.S. 49, 70 (1973) (Douglas, J., dissenting); Miller v. California, 413 U.S. 15, 37 (1973) (Douglas, J., dissenting).

$=413$ U.S. 15 (1973). Chief Justice Burger, writing for the majority, was joined by Justices White, Blackmun, Powell, and Rehnquist.

23 Id. at 24-25, 37 (quoting Memoirs, 383 U.S. at 419) (emphasis added). The new Miller test for obscenity was:

(a) whether "the average person, applying contemporary community standards," would find that the work, taken as a whole, appeals to the prurient interest . . . [Roth]; (b) whether the work depicts or describes, in a patently offensive way, sexual conduct specifically defined by the applicable state law; and (c) whether the work, taken as a whole, lacks serious literary, artistic, political, or scientific value.

Id. at 24 .

24 Id. at 30.

25 Id.

2 See Jenkins v. Georgia, 418 U.S. 153, 160 (1974) (overturning a jury's determination that the film "Carnal Knowledge" was obscene). Thus, jury determinations are fixed by "substantive constitutional limitations, deriving from the First Amendment." 
the Court now shows deference to local determinations, both under state obscenity laws and under federal laws.

\section{B. Regulation of "Less Protected" Speech: The Importance of Context}

When he joined the Court, Justice Stevens thus faced two opposing viewpoints. The Court majority, unable to precisely define obscenity on a national basis, deferred largely to local determinations. The minority, similarly unable to define the term, declined to permit regulation of obscenity under most circumstances. If the Justices agreed that obscenity fell outside the realm of protected speech, they divided sharply on whether the definitional problem precluded regulation of obscenity in a manner anticipated by the protected/unprotected distinction. Justice Stevens has apparently sided with the minority in concluding both that a nationwide definition is impracticable and that community standards are an undesirable substitute for first amendment protection. But he has developed from these conclusions a very different analysis of the proper scope of first amendment protection.

The nature of Justice Stevens's analysis appears most starkly in his dissent in Smith $v$. United States. ${ }^{27}$ Smith concerned a federal prosecution for mailing obscene materials. Following its approach in Miller, the majority upheld a conviction reached according to the community standards of Iowa, even though the statute allegedly violated was federal. ${ }^{28}$ Justice Stevens, in contrast, considered it "obvious" that a "federal statute defining a criminal offense should prescribe a uniform standard applicable throughout the country."29 He reasoned that the diversity that made a national standard of offensiveness impossible to identify also precluded definition of state standards. The assumption that jurors know the private tastes and values of their neighbors "does not apply to most segments of our diverse, mobile, metropolitan society." 30 Finally, he argued that "in some ways the community standard concept is even more objectionable than a national standard," 31 largely because of the subjec-

"7 431 U.S. 291, 311 (1977) (Stevens, J., dissenting).

${ }^{2 s} 18$ U.S.C. $\$ 1461$ (1976). At the time of petitioner's alleged crimes, the state of Iowa had prescribed no applicable standards for judging obscenity. The majority concluded that the jury was able to determine community standards without such a legislative definition. 431 U.S. at 301-08.

2 431 U.S. at 312 (Stevens, J., dissenting).

* Id. at 314 n.10.

"Id. at 314 . 
tivity, unreliability, and unreviewability of jury determinations of obscenity.

Although voting with the dissenters to invalidate criminal convictions based on such determinations, Justice Stevens refused to join in their conclusion that the inability of the judiciary to define obscenity precluded most state action against sexually explicit speech. Rather, in a striking departure from the position of the minority, he concluded that the definitional problems would be ameliorated if local regulation operated through civil rather than criminal liability. "[T] he line between communications which 'offend' and those which do not," he conceded, "is too blurred to identify criminal conduct. It is also too blurred to delimit the protections of the first amendment." 32 The blur, however, becomes a flexibility that is itself a "desirable feature" when part of a civil rule designed to protect "the individual's right to select the kind of environment in which he wants to live." ${ }^{33}$ Quoting Justice Sutherland's famous aphorism in Village of Euclid v. Ambler Realty Co., "[a] nuisance may be merely a right thing in the wrong place-like a pig in the parlor instead of the barnyard," Justice Stevens argued that nuisance law provides the most suitable means of regulating the varieties of offensive speech and the circumstances in which it appears without depriving it of all its first amendment protection.

Such an approach becomes possible, however, only upon the abandonment of Roth's strict dichotomy of protected and unprotected speech. If the first amendment makes certain speech inviolable, no regulation, even civil sanctions keyed to the context in which the speech appears, is permissible and the need to distinguish unprotected from protected speech-to define obscenity-reappears. As a result, Justice Stevens in Smith necessarily rejected outright the notion that "all communications within the protected area are equally immune from governmental restraint, whereas those outside that area are utterly without social value and, hence, deserving of no protection." ${ }^{35}$ Moreover, he recognized a class of speech, ranging from unprotected obscene speech to protected nonobscene, but sexually related speech, that may be regulated depending on its context, "[a]s long as the government does not totally suppress protected speech and is faithful to its paramount obligation of complete

2 Id. at 316. See also Rendleman, Civilizing Pornography: The Case for an Exclusive Obscenity Nuisance Statute, 44 U. CHI. L. REv. 509 (1977).

s 431 U.S. at 317.

अ 272 U.S. 365,388 (1926), quated at 431 U.S. at 317.

ss 431 U.S. at 318. 
neutrality with respect to the point of view expressed." 36

In support of his rejection of the Roth dichotomy, Justice Stevens cited his earlier opinion in Young $v$. American Mini Theatres, Inc. ${ }^{37}$ Mini Theatres not only provides a lengthy justification for distinguishing among varieties of protected speech, it also indicates how Justice Stevens's analysis operates in practice. In Mini Theatres, operators of two adult movie theatres challenged a Detroit "anticlustering" zoning ordinance prohibiting certain specifically defined "regulated uses"-for example, adult bookstores, adult movie theaters, or cabarets featuring topless or nude dancing ${ }^{38}$ - within one thousand feet of more than two other such uses.

After disposing of vagueness ${ }^{39}$ and straight first amendment claims, ${ }^{40}$ Justice Stevens directed his attention primarily to the operators' argument that the statute denied them equal protection because it discriminated against certain movie theaters on the basis of the content of their films. ${ }^{41} \mathrm{He}$ admitted that some Supreme Court cases, read literally and without regard to their facts, "would absolutely preclude any regulation of expressive activity predicated in whole or in part on the content of the communication." 42 Nevertheless, the Justice pointed out that in many situations the Court had endorsed discrimination between forms of speech on the basis of content. ${ }^{43}$ Thus, he concluded that lines could be drawn between

s Id.

37427 U.S. 50 (1976) (Stevens, J.).

"An "adult theater" was defined as one which presents "material distinguished or characterized by an emphasis on matter depicting, describing or relating to 'Specified Sexual Activities' or 'Specified Anatomical Areas." "Id. at 53. These terms, in turn, were precisely defined. "Specified Anatomical Areas," for example, included "[1]ess than completely and opaquely covered: (a) human genitals, pubic region, (b) buttock, and (c) female breast below a point immediately above the top of the areola." Id. at 53 n.4.

30 Justice Stevens found that the statute "unquestionably" applied to the respondents, id. at 58-59, and that they lacked standing to challenge vagueness with respect to other persons because the case did not concern a threat to the maintenance of " $a$ free and open market for the interchange of ideas." Id. at 60 . This disposition foreshadowed Justice Stevens's constitutional argument that sexually explicit speech is entitled to less protection than other, more important forms of speech. See text and notes at notes 55-63 infra.

14 The first amendment claim was rejected because all movie theaters were subject to presumably valid zoning regulations. The only reason for respondents' challenge was that some movie houses were treated differently from others. This claim was considered under the rubric of equal protection.

"In his equal protection analysis, Justice Stevens was joined by Chief Justice Burger and Justices White and Rehnquist. Justice Powell, who joined in the other portions of the opinion, concurred separately on the equal protection issue.

${ }^{42} 427$ U.S. at 65 (discussing Police Dep't. v. Mosley, 408 U.S. 92 (1972)).

13 Among the areas in which the Court has approved discrimination on the basis of the content of speech, Justice Stevens discussed incitement to crime or violence, fighting words, release of wartime information, defamation of public officials, commercial speech, and obscenity. Id. at 66-70 (citing cases). 
sexually explicit and other speech "without violating the government's paramount obligation of neutrality in its regulation of protected communication." 44 More specifically, he said that "society's interest in protecting this type of expression is of a wholly different, and lesser, magnitude than the interest in untrammeled political debate." 45 In explaining this distinction, Justice Stevens noted that "few of us would march our sons or daughters off to war to preserve the citizen's right to see 'Specified Sexual Activities' exhibited in the theatres of our choice." 46

Having decided that such discrimination was permissible, Justice Stevens had no difficulty in upholding the Detroit ordinance. Evidence had been introduced tending to show that concentration of adult movie theaters was related to neighborhood deterioration and increases in crime. ${ }^{47}$ Applying a low level of scrutiny, ${ }^{48}$ Justice Stevens noted that "the city's interest in attempting to preserve the quality of urban life is one that must be accorded high respect,"49 and he concluded that "the city's interest in the present and future character of its neighborhoods adequately supports its classification of motion pictures." 50

In sum, the arialysis of Smith and Mini Theatres develops two central themes. First, government may restrict speech on the basis of its content when the speech, although not wholly outside the protection of the first amendment, is so far removed from the fundamental concerns of the amendment that its limitation will not seriously impair basic liberties. Second, to preserve the free marketplace of ideas and government neutrality within it, government regulation, when tied to content, must not unduly restrict speech and must not favor any particular viewpoint. Thus, for example, Justice Stevens concluded that sexually related speech, as distinguished

\footnotetext{
"Id. at 70.

is Id.

"Id.

17 Id. at $71 \&$ n. 34 .
}

48 Mini Theatres reflects a highly deferential approach to the problem, given the first amendment implications. Such a minimal level of scrutiny is ordinarily reserved for economic matters. See, e.g., City of New Orleans v. Dukes, 427 U.S. 297 (1976). But by characterizing the Detroit ordinance as "nothing more than a limitation on the place where adult films may be exhibited," 427 U.S. at 71, Justice Stevens does effectively treat Mini Theatres as a case of economic regulation-a zoning problem. Cf. id. at 73-84 (Powell, J., concurring) (explicitly treating Mini Theatres as a zoning case with only incidental effect on speech). Justice Stevens did not discuss alternative means of achieving the same results without so stifling a classification; this also is consistent with economic equal protection. See Developments in the Law-Equal Protection, 82 HaRv. L. REv. 1065, 1082-87 (1969).

11 427 U.S. at 71.

so Id. at 72 . 
from political speech, is not fully protected and may be regulated even if it is not obscene. At the same time, all such material, even when obscene, is "entitled to at least a modicum of First Amendment protection," s1 so that the only permissible regulation is that seeking to abate a "nuisance"-such as public displays of erotic materials ${ }^{52}$ or dissemination to juveniles ${ }^{53}$-or serving some significant state interest-such as the prevention of urban blight. If the speech offends no one and the state asserts no true interest, the Justice noted, "we must rely on the capacity of the free marketplace of ideas to distinguish that which is useful or beautiful from that which is ugly or worthless." ${ }_{54}$

The role of context in determining the permissible regulation of less-protected speech, as well as the definition of this category of speech itself, is further elaborated in Justice Stevens's opinion for the Court in FCC $v$. Pacifica Foundation. ${ }^{55}$ Pacifica concerned an FCC warning issued to a radio station that broadcast George Carlin's monologue, "Filthy Words," which satirizes society's verbal mores, largely by repeating various expletives in different combinations. ${ }^{56}$ The Justice reaffirmed his break with the Roth approach by permitting civil regulation of profane speech, which had previously been understood as fully protected. Responding for the Court to the question "[w]hether a broadcast of patently offensive words dealing with sex and excretion may be regulated because of its content," Justice Stevens asserted that the words in the Carlin mono-

s1 431 U.S. at 312 .

52 Cf. Erznoznik v. City of Jacksonville, 422 U.S. 205 (1975) (disallowing prohibition of explicit films at drive-in movie theaters). Justice Stevens distinguished Erznoznik in Mini Theatres, 427 U.S. at 71 n.34, on the grounds that the secondary effect in Erznoznikdisruption of traffic-would also result from nonexplicit films. The distinction is hardly compelling: theaters showing nonexplicit films might also have a deleterious effect on neighborhoods. See also Paris Adult Theatre I v. Slaton, 413 U.S. 49, 113 (1973) (Brennan, J., dissenting); Note, The Chilling Effect in Constitutional Law, 69 CoLum. L. REv. 808 (1969).

ss Cf. Ginsberg v. New York, 390 U.S. 629 (1968) (upholding conviction for selling to a 16-year old materials that were not obscene for adults).

s Smith v. United States, 431 U.S. 291, 321 (1977) (Stevens, J., dissenting) (footnote omitted).

ss 98 S.Ct. 3026 (1978). Justice Stevens, writing for the Court, was joined in the entirety of his opinion by Chief Justice Burger and Justice Rehnquist. Justices Powell and Blackmun concurred, differing with Justice Stevens's conclusion that sexually explicit speech is less valuable than other forms of speech. They relied instead on the distinctive character of the broadcast media as a justification for increased governmental regulation. Id. at 3046-47 (Powell, J., concurring).

s. The Carlin monologue is reprinted as an appendix to the opinion of the Court. Id. at 3041-43 app.

37 Id. at 3038 (Stevens, J.). The dissenting Justices, Stewart, Brennan, Marshall, and White, argued that the constitutional issue need not be reached. They would have construed 
logue "lack literary, political, or scientific value," but nevertheless "are not entirely outside the protection of the First Amendment." He concluded that the degree of protection accorded such speech varies with the context in which it occurs, and that radio broadcasting is so uniquely pervasive in the lives of Americans, intruding even into the home, and so uniquely accessible to children that the FCC acted within its powers in issuing the warning..$^{59}$ The holding was limited to its facts; "a host of variables" made the FCC action appropriate. ${ }^{\circ 0}$ Again alluding to the words of Justice Sutherland, Justice Stevens concluded: "We simply hold that when the Commission finds that a pig has entered the parlor, the exercise of its regulatory power does not depend on proof that the pig is obscene." 61

Justice Stevens emphasized that the scope of permissible regulation is narrowly circumscribed. When speech offends because of the speaker's opinion, protection is required: $:^{62}$ the government must remain neutral when political and social opinions are concerned. Thus, "[i]f there were any reason to believe that the Commission characterization of the Carlin monologue as offensive could be traced to its political content-or even to the fact it satirized contemporary attitudes about four letter words-First Amendment protection might be required." ${ }^{83}$ But if, as Justice Stevens found in Pacifica, the regulation goes only to the character and impact of the speech, rather than to the opinion it expresses, it will be upheld.

\section{Implications for First Amendment Doctrine}

On its face, Justice Stevens's approach to the first amendment in Mini Theatres and Pacifica represents a reasonable accommodation of the interests of both the individual and the community by striking a balance between free expression and the need to mitigate those effects of unrestricted speech customarily viewed as most threatening to the community. This balancing occurs at two levels. First, a balancing of individual and community interests takes place in resolving the question presented in any particular case. In Mini

18 U.S.C. $\$ 1464$ (1976) to limit the FCC's censorship powers to obscene speech. See 98 S.Ct. at 3055-56.

ss Id. at 3039.

3s Id. at $3040-41$.

* Id. at 3041 . Especially important was the fact that the broadcast was made in the afternoon, a time when children were likely to be listening. Justice Stevens did not make clear what degree of scrutiny the Court should apply to the particulars of the regulatory body's decision regarding context.

"Id.

12 Id. at 3038.

is Id. at 3038-39. 
Theatres, for example, Justice Stevens upheld the legitimacy of the Detroit ordinance in part by reference to the strength of the state interest underlying it-the preservation of urban neighborhoods ${ }^{64}$-and in part by reference to the weakness of the opposing individual interest-the absence of any claim that the ordinance in any way diminished either the individual's access to sexually explicit material or the theater owner's right to distribute such material..$^{65}$

Mini Theatres also involved balancing of a more general sort. Justice Stevens's very conclusion that sexually explicit speech, as a class, is entitled to less than full first amendment protection presupposes a weighing of the potential such material exhibits for contributing to the marketplace of ideas against the threat it may pose to other societal interests. Justice Stevens nowhere explains how he reached his determination of the relationship between sexually explicit speech and the first amendment, but the most compelling argument may simply be historic. Faced with long-standing public, legislative, and judicial concern about the impact of such materials, Justice Stevens has tried to develop a reasonable, pragmatic approach to the regulation of such materials that frankly accepts society's low valuation of them and at the same time protects basic first amendment values.

The practical advantage of the Justice's approach, with its appeal to common sense, should not obscure the problems in his position. Even apart from his questionable use of precedent regarding the Court's previous ventures into content-based classification, ${ }^{86}$ Justice Stevens's attempt to apply a balancing approach is troubling in that it seems to proceed from an inadequately articulated set of principles defining the first amendment interests it seeks to protect. In particular, in appearing to jettison the strict requirement that an utterance share "no essential part of any exposition of ideas" before it can be regulated, ${ }^{67}$ the Justice creates the possibility of a considerably broader and more nebulous class of regulable expression than that heretofore held unprotected. Perhaps because the unifying principle behind these less-protected forms of speech is unclear-consisting solely of the principle that some speech is so far

" 427 U.S. at $55,71 \&$ n.34.

is Id. at 62, 71-72.

"As the dissenters in Mini Theatres were quick to note, id. at 85-87, none of the cases in which the Court had looked to content involved discrimination among different types of protected speech. Rather, the Court was generally concerned with the question whether the speech at issue fell within a protected category.

${ }^{17}$ Pacifica, 98 S. Ct. at 3039 (quoting Chaplinsky v. New Hampshire, 315 U.S. 568, 572 (1942) (fighting words)). 
from the concerns of the first amendment that the need to protect it is "of a wholly different, and lesser, magnitude than the interest in untrammeled political debate" ate the categories of speech that fall within the broader class and to discuss why they fall there. In Smith and Mini Theatres, for example, the concern was with sexually related speech, but the Justice never indicated whether such speech forms a separate category of less-protected speech. Furthermore, the Justice's aphoristic statement of his working principle for determining the value of speech $^{68}$ offers a standard that varies not just with the sensibilities of local communities, but with the shifting political climate as well.

Pacifica underscores the problem of categorization by placing profanity within the range of permissible content regulation. As Justice Stevens insisted, profanity shares with sexually explicit speech a focus on the "intimacies" of "certain bodily functions"70 and often offends "for the same reasons that obscenity offends." "? Because profanity engenders social concerns that are quite distinct from those tied to obscenity and the like, ${ }^{72}$ however, if it is viewed as a part of the category of sexually related and hence less-protected speech, profanity weakens the theoretical unity of that category. On the other hand, if viewed as a new category of less-protected speech, profanity raises the questions whether such a category has a principled basis and whether any clear and sensible limit on the number and variety of less-protected categories is available. The effect is to allow the classification of speech as less protected to turn primarily on the extent to which the community finds it objectionable, a result threatening to both the marketplace of ideas and the goal of governmental neutrality.

The second theme of Justice Stevens's free speech analysis seemingly responds to this latter difficulty by limiting governmental regulation of the content of any speech. ${ }^{73}$ This formulation of a content-neutral requirement, however, departs from the Court's earlier decisions recognizing that the first amendment must protect the "emotive function" of speech as well as its "cognitive content."74

\footnotetext{
4 Mini Theatres, 427 U.S. at 70.

- See text and notes at notes 45-46 supra.

to 98 S.Ct. at 3039 n.23.

"Id. at 3039 (footnote omitted).

72 See Rutzick, Offensive Language and the Evolution of First Amendment Protection, 9 HaRv. C.R.-C.L.L. Rev. 1, 1-2 (1974).

73 See text and notes at notes 62-63 supra.

74 "[M] uch linguistic expression serves a dual communicative function: it conveys not only ideas capable of relatively precise, detached explication, but otherwise inexpressible emotions as well." Cohen v. California, 403 U.S. 15, 26 (1971).
} 
A speaker may directly intend his particular form of political or social expression to evoke strong emotional responses from his audiences: nazis may choose to march in Jewish suburbs, the Ku Klux Klan may demonstrate in black neighborhoods, abortion opponents may offer pictorial or verbal descriptions specifically designed to shock and alarm. Although the cognitive content may not be the most important element in such speech, denial or restriction of the speaker's chosen form of communication still constitutes a restriction on the freedom to communicate. The formulation is no more defensible, moreover, when viewed, as Justice Stevens indicates it might be, ${ }^{75}$ in the more familiar guise of an attempt to restrict form rather than content. So long as human communication retains its subtle character as a union of form and substance, such a distinction will be illusory. ${ }^{76}$

Nor can this difficulty in Justice Stevens's focus on the source of the offense be remedied by seeking to restrict only the deleterious "secondary effects" of offensive speech. ${ }^{77}$ Such a distinction suffers from the same difficulties surrounding the distinction between form and content. The nuisance effects of speech may be the result of nothing more than the community's reaction to such speech: the deterioration of neighborhoods as a result of a proliferation of movie houses exhibiting sexually explicit films may itself be a reaction of the community to such films. The desire to protect children and unwilling listeners from profane language is equally a reflection of the social response to certain speech. To the extent one can separate such effects from the simple social desire to isolate the community from offending language, the same analysis could be applied to deny protection to political speech that is likely to evoke a violent reaction in certain members of the community. In short, to assert that certain speech may be regulated because of its effects upon the community is specifically to sanction under the Constitution a censorial role for the community that is inconsistent with the Justice's basic analytical framework. ${ }^{78}$

It is important to keep the significance of Justice Stevens's opinions in perspective. The results reached by the Justice in Mini Theatres and Pacifica are in themselves probably not objectiona-

7s Pacifica, 98 S.Ct. at 3037 n.18. See also id. at 3038-39 (first amendment protection might be needed if Carlin monologue were offensive because of its political or satirical content, rather than its sexually and scatalogically explicit mode of expression).

"See id. at 3053 (Brennan, J., dissenting) ("The idea that the content of a message and its potential impact on any who might receive it can be divorced from the words that are the vehicle for its expression is transparently fallacious.").

$n$ See generally L. TriBE, supra note 12, § 12-20.

"See text and notes at notes 30-31 supra. 
ble. ${ }^{79}$ The regulation of speech in Pacifica, for example, involved only the issue of a warning letter to a participant in a highly regulated industry - an industry in which the government exercises considerable control over program content in other areas. ${ }^{80}$ Justice Stevens was careful to limit the decision to its particular facts, and so limited it poses little danger to freedom of expression. It is not the soundness of Justice Stevens's individual decisions that is troublesome; it is the failure of his case-by-case adjudication to provide workable principles for future decisionmaking. The Justice based both his Pacifica and Mini Theatres opinions on similar broad rationales, upholding a species of content regulation in two different contexts. Yet these opinions offer virtually no guidance to legislators or lower courts in determining the proper limits of such regulation.

Justice Stevens has yet to face the difficult line-drawing problems his approach entails. Perhaps he should not be faulted for failing to decide cases not yet before him. Assuming, as Justice Stevens does, that some government regulation of speech is justified, the Justices's approach does focus on factors that must be considered if regulation is to rest upon a firm and principled basis. The context in which a given speech act occurs, the extent to which the speech implicates the fundamental purposes of the first amendment, and the governmental motive in restricting the speech are significant variables in any calculus of the scope of permissible regulation. The Justice's refusal to validate classifications based on the political content of speech and his insistence that regulation not impose debilitating restrictions on access to the marketplace for any speech reflects his commitment to preserving the role of the individual as the arbiter of the value of particular speech acts. Nevertheless, his pragmatic approach to first amendment ad-

"One's opinion of Justice Stevens's free-speech jurisprudence is, to a large extent, a matter of one's political point of view: to those who emphasize personal freedom, Mini Theatres and Pacifica introduce a dangerous doctrine; to those who would accept greater state control of communication, these cases provide a welcome dose of common sense.

Political speech of broadcasters is subject to regulation under the fairness doctrine and other FCC regulations. See, e.g., Editorializing By Broadcast Licensees, 13 F.C.C. 1246 (1949). See also 47 U.S.C. \& 315(a) (1970) (congressional approval of the faimess doctrine). Indeed, the discussion of public issues is in some ways more closely regulated than other forms of speech, such as product commercials. See Fairness Report, 48 F.C.C.2d 1, 26 (1974). The fairness doctrine was held not to violate the first amendment in Red Lion Broadcasting Co. v. FCC, 395 U.S. 367 (1969). The Court, in an opinion by Justice White, distinguished the broadcast media from other media such as the printed press on the basis of the scarcity of the airways and the public trusteeship role of the broadcast licensee. Courts have also claimed that broadcasting is so pervasive and intrusive as to make listeners a "captive audience." See, e.g., CBS v. Democratic Nat'l Comm., 412 U.S. 94, 127-28 (1973). Given this special status of broadcasted speech, in which first amendment freedoms are less highly protected, Justice Stevens's conclusion that profanity over the airwaves may be regulated is not surprising. 
judication and his failure to enunciate for the lower courts the precise dimensions of the less-protected speech category may result in greater intrusions on the freedom of expression than he would be willing to countenance.

\section{The Establishment Clause}

The establishment clause of the first amendment provides simply that "Congress shall make no law respecting an establishment of religion." the institution of an established church in the United States. ${ }^{82}$ More broadly, the provision has been viewed as prohibiting federal or state encouragement of any kind of religion-whether a specific sect or religion in general. ${ }^{83}$ In defining these limitations in the area of state aid to sectarian education, the Court has developed a threepart test. To pass constitutional muster, a statute providing aid must have a "secular legislative purpose," it must, in primary effect, neither advance nor inhibit religion, and it must not "foster an excessive government entanglement with religion." 84 In practice, this test has not always led to predictable results, especially in cases involving aid to private schools, ${ }^{85}$ in which, as one member of the Court has noted, the decisions "draw lines that often must seem arbitrary." 86

Characteristically, Justice Stevens has declined to follow the majority on its current path. His course, however, seems strangely

81 U.S. Const. amend. I.

82 See Everson v. Board of Educ., 330 U.S. 1, 15 (1947) ("Neither a state nor the Federal Government can set up a church.").

" See id. ("Neither [a state nor the Federal Government] can pass laws which aid one religion, aid all religions, or prefer one religion over another. Neither can force nor influence a person . . . to profess a belief or disbelief in any religion.").

\& Wolman v. Walter, 433 U.S. 229, 236 (1977) (plurality opinion of Blackmun, J.); Committee for Pub. Educ. \& Religious Liberty v. Nyquist, 413 U.S. 756, $772-73$ (1973).

ss The Court has approved provision of money for bus transportation to parents of private school pupils, Everson v. Board of Educ., 330 U.S. 1 (1947), release of public school pupils for off-campus religious instruction during school hours, Zorach v. Clauson, 343 U.S. 306 (1952), loan of textbooks to private school students, Board of Educ. v. Allen, 392 U.S. 236 (1968), and construction of facilities for religiously affiliated colleges and universities, Tilton v. Richardshon, 403 U.S. 672 (1971), while disallowing religous instruction within public school classrooms during the school day, McCollum v. Board of Educ., 333 U.S. 203 (1948), offering of prayers-even nonsectarian ones-in public schools, Abington School Dist. v. Schempp, 374 U.S. 203 (1963), provision of salary supplements to teachers of nonreligious subjects in sectarian schools, Lemon v. Kurtzman, 403 U.S. 602 (1971), tax relief or tuition reimbursement for parents of private school pupils, Committee for Pub. Educ. \& Religious Liberty v. Nyquist, 413 U.S. 756 (1973), and loans of instructional materials other than textbooks to private schools or school children, Meek v. Pittenger, 421 U.S. 349 (1975).

s Wolman v. Walter, 433 U.S. 229, 262 (1977) (Powell, J., concurring in part, dissenting in part). 
at odds with his usual tendency to shun general rules in favor of decisions carefully calibrated to the facts of the case. ${ }^{87} \mathrm{He}$ has adopted the view that "a state subsidy of sectarian schools is invalid regardless of the form it takes." 88 In Roemer $v$. Board of Public Works, ${ }^{89}$ his first establishment clause opinion, Justice Stevens dissented from a decision upholding the constitutionality of a Maryland program providing noncategorical grants-restricted to nonsectarian purposes-to private colleges and universities. $\mathrm{He}$ "substantially" cused on the program's subsidy of religious activity. Justice Stevens also wrote a one paragraph dissent to "add emphasis to the pernicious tendency of a state subsidy to tempt religious schools to compromise their religious mission without wholly abandoning it."92

Justice Stevens again dissented in Wolman $v$. Walter. ${ }^{93}$ In Wolman the Court ${ }^{94}$ approved an Ohio statute providing nonpublic school pupils with books, standardized testing and scoring services, diagnostic services, and therapeutic and remedial services, but struck down the statute's aid for instructional materials and equipment and field trip transportation. ${ }^{95}$ With the exception of the diagnostic and therapeutic services-which he compared to public health services ${ }^{96}$-Justice Stevens would not permit any of the assis-

87 See, e.g., text and notes at notes 64-69 supra and notes $323-345$ infra.

ss Wolman v. Walter, 433 U.S. 229, 265 (1975) (Stevens, J., concurring in part, dissenting in part).

s 426 U.S. 736, 775 (1976) (Stevens, J., dissenting). Justice Blackmun wrote for a plurality, joined by Chief Justice Burger and Justice Powell. Justices White and Rehnquist concurred in the judgment. Justices Brennan, Stewart, Marshall, and Stevens dissented.

so Id.

"Id. at 770 (Brennan, J., dissenting).

2I Id. at 775 (Stevens, J., dissenting).

${ }^{2} 433$ U.S. 229, 264 (1977) (Stevens, J., concurring in part, dissenting in part).

"Justice Blackmun wrote for the plurality, although only parts of his opinion are labeled the opinion of the Court. Justice Stewart apparently joined all parts of his opinion. Chief Justice Burger and Justices Rehnquist and White agreed with those sections upholding the aid, and dissented from those sections striking it down. Justice Powell agreed with those sections upholding the aid, and with that section striking down the grant of instructional materials and equipment, but dissented from the decision to strike down the aid for field trips. Justices Brennan, Marshall, and Stevens agreed with the sections striking down the aid, agreed with the sections upholding the therapeutic and diagnostic services, and dissented from the sections upholding all other forms of aid.

s The rationale for the Court's distinction among the types of aid is somewhat obscured by the organization of the opinion, which analyzes each type of aid individually, without making comparisons. With the exception of the diagnostic and therapeutic services, at least six of the Justices perceived no constitutional distinction among the other types of aid.

" 433 U.S. at 266. The diagnostic and therapeutic services related primarily to speech and hearing defects. The programs were not integrated into the school regimen; for example, the therapeutic services were provided in mobile units located away from the private school grounds. Id. at 241,245 (plurality opinion). 
tance. All of the aid, he said, supports "the school's educational mission, which at heart is religious." 97 The Justice advocated abandonment of the three-part test used by the plurality and a return to the rule in Everson v. Board of Education:" "No tax in any amount, large or small, can be levied to support any religious activities or institutions, whatever they may be called, or whatever form they may adopt to teach or practice religion." test, Justice Stevens said, "[w] hat should be a "high and impregnable' wall between church and state, has been reduced to a 'blurred, indistinct, and variable barrier." "100

Justice Stevens's position may best be explained by his concentration on the adverse effects of state aid on religious institutions, rather than by the effects of state aid to religion on nonbelievers or on the polity. In his Wolman dissent, he twice referred to Clarence Darrow's remark in the Scopes trial that when religion has received support from the state, "it has harmed both the public and the religion that it would pretend to serve." 101 Accordingly, Justice Stevens was not swayed by the considerable public benefits accruing from aid to private education. ${ }^{102}$ In Wolman he illustrated the "pernicious tendency . . . to tempt religious schools to compromise their religious mission" with two practical examples. ${ }^{103}$ The Ohio statute, he pointed out, caused the religious schools to "relinquish their religious exclusivity"104_a requirement for receiving funds. Moreover, he noted, the statute would pressure the private schools to avoid textbooks that "present a religious perspective on secular subjects"105 so that they may be paid for by the state.

Justice Powell's statement that "at this point in the 20th century we are quite far removed from the dangers that prompted the Framers to include the Establishment Clause in the Bill of

"Id. at 265 (Stevens, J., concurring in part, dissenting in part).

" 330 U.S. 1 (1947).

"Id. at 16.

in 433 U.S. at 266 (quoting id. at 236 (plurality opinion (quoting Lemon v. Kurtzman, 403 U.S. 602, 613 (1971)))) (footnote omitted).

iil 433 U.S. at 264, 266. See also A. DE Toceueville, Democracy in America 298 (Anchor Books ed. 1969) ("Hence any alliance with any political power whatsoever is bound to be burdensome for religion. It does not need their support in order to live, and in serving them it may die.").

102 According to Justice Powell, some of the public benefits from aid to private schools are: the provision of educational alternatives apart from the sectarian purpose, the stimulus to competition in the educational industry, the relief from the expense of educating all children in public schools, and the facilitation of high quality education. 433 U.S. at 262 (Powell, J., concurring in part, dissenting in part).

${ }^{103}$ Id. at $266 \mathrm{n} .7$ (Stevens, J., concurring in part, dissenting in part).

in Id.

in Id. 
Rights," 108 may be correct with regard to the creation of a state church. The novelty of Justice Stevens's position lies not in his disagreement with Justice Powell's assertion, but in his invocation of a concern that has not traditionally influenced the Court's development of establishment clause doctrine: the insidious tendency of state money to secularize recipient institutions. ${ }^{107}$ The restrictions on state aid to sectarian schools imposed under the three-part test combined with the growing dependence of such schools on state aid for financial survival make this a peculiarly contemporary concern. If it is acknowledged that the potential secularization of religious institutions is an evil within the purview of the establishment prohibition, Justice Stevens's absolutist position ${ }^{108}$ may be required to prevent that secularization.

\section{Protection from Government Searches}

The fourth amendment protects the "right of the people to be secure ... against unreasonable searches and seizures" and requires that "no Warrants shall issue, but upon probable cause."108 Historically, the doctrinal content of the amendment has been ill-defined. ${ }^{10}$ The Court has had particular difficulty forging a

${ }_{106}$ Id. at 263 (Powell, J., concurring in part, dissenting in part).

${ }^{107}$ In an age in which government has increased tremendously in size, government "largesse" may be as great a threat to the independent and diverse development of religious institutions as was direct government association in an earlier time. It may be true that the framers were little aware of this danger. Nevertheless, to the extent that state aid to religion encourages homogenization and secularization of religious institutions, prohibition of that aid may be entirely consistent with the goals of the establishment clause. See L. TriBE, supra note 12, § 14-3, at 816-19; Gianelli, Religious Liberty, Non-Establishment, and Doctrinal Development Part II, The Non-Establishment Principle, 81 HARv. L. Rev. 513, 516-26 (1968).

${ }^{105}$ Although Justice Stevens appears to have taken an absolutist position regarding state aid to sectarian schools, he apparently has not adopted such a strict position in other areas of potential church-state conflict. For example, in Serbian E. Orthodox Diocese v. Milivojevich, 426 U.S. 696, 725 (1976), decided the same day as Roemer, Justice Stevens joined Justice Rehnquist, dissenting from the decision that a state court has no power to interfere with the judgment of a hierarchical church concerning leadership of the church. Justices Rehnquist and Stevens argued that the civil courts of the state have authority to resolve conflicting claims to real property, and that to do so requires investigation beyond mere "ecclesiastical paper title." Id. at 726.

100 U.S. Const. amend. IV.

"10 See Chimel v. California, 395 U.S. 752 (1969); United States v. Rabinowitz, 339 U.S. 56 (1950); Trupiano v. United States, 334 U.S. 699 (1948). The Court has acknowledged that its body of fourth amendment precedent is "something less than a seamless web." Cady v. Dombrowski, 413 U.S. 433,440 (1973). The lack of a consistent fourth amendment doctrine has not escaped the attention of the commentators: "The absence of a continuously developing rationalization of the amendment has enabled the Court to change direction, even to veer rapidly and sharply, without too obvious inconsistency; but the result is a body of doctrine that is unstable and unconvincing." Weinreb, Generalities of the Fourth Amendment, $42 \mathrm{U}$. 
consistent interpretation of the relationship between the amendment's two clauses. ${ }^{11}$ Although members of the Court agree that the amendment generally is a safeguard against arbitrary governmental intrusions into individual privacy, ${ }^{112}$ a majority of the Justices of the Burger Court adhere to the view that the protection against unreasonable searches guaranteed by the first clause is achieved primarily by requiring that searches be conducted pursuant to judicially authorized warrants ${ }^{113}$ issued upon probable cause. Thus, in its recent decisions the Court has treated compliance with the warrant requirement as the touchstone for determining the "reasonableness" of a search, relying on earlier statements that "[e]xcept in certain carefully defined classes of cases, a search of private property without proper consent is 'unreasonable' unless it has been authorized by a valid search warrant."114

Recent difficulties with the Court's view of the reasonableness and warrant provisions are attributable to two landmark fourth amendment developments in 1967. In the first of these, Camara $v$. Municipal Court, ${ }^{115}$ the Court held that, absent consent, the fourth amendment prohibited an "administrative" search of residential premises without a warrant. ${ }^{116}$ The Court rejected, however, appellant's argument that such a search must be predicated on probable cause to believe that a violation of health and safety regulations existed. In reaching its conclusion that a more general probable cause showing was sufficient, the Court balanced "the need to search against the invasion which the search entails." 117 In a com-

Chr. L. Rev. 47, 49 (1974). Because of this absence of settled doctrine, this section will compare Justice Stevens's jurisprudence with that of the other current members of the Court.

i' See generally J. Landynski, Search and Seizure and the Supreme Court 42.43 (1966) (describing three possible interpretations of the relationship between the two clauses).

112 See, e.g., Michigan v. Tyler, 436 U.S. 499, 504 (1978) (quoting Camara v. Municipal Court, 387 U.S. 523, 528 (1967)); Marshall v. Barlow's, Inc., 436 U.S. 307,327 (1978) (Stevens, J., dissenting).

${ }^{113}$ See, e.g., Marshall v. Barlow's, Inc., 436 U.S. 307, 312 (1978) (majority opinion); Terry v. Ohio, 392 U.S. 1, 20-21 (1968); Camara v. Municipal Court, 387 U.S. 523, 528 (1967); Johnson v. United States, 333 U.S. 10, 14 (1948); Agnello v. United States, 269 U.S. 20, $30-$ 33 (1925). A variety of situations in which a search warrant is not required, justified by necessity or exigent circumstances, have been delineated. See, e.g., Chambers v. Maroney, 399 U.S. 42 (1970); Terry v. Ohio, 392 U.S. 1 (1968); United States v. Rabinowitz, 339 U.S. $56(1950)$.

i' Camara v. Municipal Court, 387 U.S. 523, 528-29 (1967).

115387 U.S. 523 (1967).

'I' Id. at 534, overruling Frank v. Maryland, 359 U.S. 360 (1959). See generally LaFave, Administrative Searches and the Fourth Amendment: The Camara and See Cases, 1967 Sup. CT. Rev. 1.

"11 387 U.S. at 536-37. The factors considered by the Court in its balancing process included: "[T]he long history of judicial and public acceptance" of such programs, the 
panion case to Camara, See $v$. Seattle, ${ }^{118}$ the Court decided that the warrant requirement imposed in Camara also applied to regulatory inspections of commercial premises. ${ }^{119}$ In order to reconcile its conclusion in See with the administrative searches required to enforce the myriad federal, state, and local health and safety regulations, ${ }^{120}$ the Burger Court majority is willing to lower the standard of probable cause for issuing "administrative warrants," but not to allow warrantless searches. ${ }^{121}$

The second significant development was the Court's holding in Warden $v$. Hayden ${ }^{122}$ that the fourth amendment does not exempt "mere evidence" from the scope of a valid search and seizure. Prior to Hayden, warrants authorized searches for and seizures of evidence directly related to a crime-instruments and fruits of the crime-but not for private papers or other documentary evidence. ${ }^{124}$ By permitting seizure of the latter, Hayden subjected a far broader class of individuals to the invasions of privacy incident to a criminal investigation. The result has been a need for the Court to reassess the probable cause requirement for warrants to search for mere evidence. ${ }^{25}$

In response to the problems engendered by these doctrinal developments, Justice Stevens has adopted a position that deviates sharply from that of the majority. Whereas the Court collapses the probable cause and reasonableness requirements into a single deter-

public interest in abating or preventing dangerous conditions, and the limited extent of the invasion of the individual's privacy. Id. at 537 .

113387 U.S. 541 (1967).

11' Id. at 545 .

120 After Mapp v. Ohio, 367 U.S. 643 (1961), state and local enforcement of state and local regulations came under fourth amendment scrutiny. Moreover, the federal government's own regulatory programs have grown immensely in the last generation. See See v. Seattle, 387 U.S. 541, 543-44 (1967).

221 See Marshall v. Barlow's, Inc., 436 U.S. 307 (1978).

122387 U.S. 294 (1967).

123 Id. at 301.

121 See Gouled v. United States, 255 U.S. 298, 309 (1921); Boyd v. United States, 116 U.S. 616 (1886). The government's interest in the goods seized was, at least at the threshold, a property interest. Hayden, 387 U.S. at 303-04. See N. LAsson, The History AND Development of the Fourth AmEndment to the United States Constitution 108 (1937) ("the property which may be searched for and seized must be such that the government or other claimant is entitled to its possession, or to which the defendant is not entitled"). In Hayden, however, this view of the governmental interest was characterized as a "fiction." $387 \mathrm{U}$.S. at 306 . The true governmental interest was to enforce the law, including regulations under the police power. Id. at 307 . The citizen's interest was not self-protection from prosecution, but privacy. Id. at 304-06. See also Camara v. Municipal Court, 387 U.S. 523, 528 (1967).

125 See Hayden, 387 U.S. at 307 ("Thus in the case of 'mere evidence,' probable cause must be examined in terms of cause to believe that the evidence sought will aid in a particular apprehension or conviction."). 
mination, ${ }^{128}$ Justice Stevens views the two clauses as imposing distinct standards. ${ }^{127} \mathrm{He}$ has argued, partly on the basis of an historical analysis of the grievances that gave rise to the fourth amendment, ${ }^{128}$ that the search warrant should not be viewed as merely a protective device for the citizen; "it also grants the government increased authority to invade the citizen's privacy." 128 Because of the intrusive nature of warranted searches, the Justice insists they must only be permitted when justified by a particularized finding of probable cause: ${ }^{130}$ the simple fact that a search is reasonable without such a finding does not justify the issuance of a warrant. Under Justice Stevens's approach, the reasonableness requirement assumes primary importance. The warrant clause simply requires that, if issued, a warrant be based upon a particularized, rather than a general, showing of probable cause. ${ }^{131}$

\section{A. Reasonable Searches and the Warrant Requirement}

Justice Stevens's most complete statement of his fourth amendment jurisprudence is his dissent in Marshall $v$. Barlow's, Inc., ${ }^{132}$ a case involving the constitutionality of warrantless searches pursuant to the Occupational Safety and Health Act (OSHA). ${ }^{133}$

${ }^{128}$ This collapse is the result of the majority's view, on the one hand, that reasonableness in most situations requires that the search be conducted pursuant to a warrant, and, on the other, that the validity of a warrant depends upon the reasonableness of the search. See, e.g., Michigan v. Tyler, 436 U.S. 499 (1978). Both the validity of the search and the validity of the warrant come to rest upon the same determination: "In determining whether a particular inspection is reasonable-and thus in determining whether there is probable cause to issue a warrant for that inspection-the need for the inspection must be weighed in terms of these reasonable goals of code enforcement." Camara v. Municipal Court, 387 U.S. 523, 535 (1967).

177 Marshall v. Barlow's, Inc., 436 U.S. 307, 325-26 (1978) (Stevens, J., dissenting) ("The Fourth Amendment contains two separate Clauses, each flatly prohibiting a category of governmental conduct.").

${ }^{123}$ For the Justice's historical analysis, see Zurcher v. Stanford Daily, 436 U.S. 547, 57778 (1978) (Stevens, J., dissenting); Marshall v. Barlow's, Inc., 436 U.S. 307, 327-28 (1978) (Stevens, J., dissenting). Justice Stevens has relied heavily on T. TAYLoR, Two STUdIES IN CONSTTTUTIONAL INTERPRETATION (1969), for his analysis of the original purpose of the warrant clause. For a somewhat different view see Frank v. Maryland, 359 U.S. 360, 374 (1959) (Douglas, J., dissenting). See also United States v. Rabinowitz, 339 U.S. 56, $69-70$ (1950) (Frankfurter, J., dissenting).

12. Michigan v. Tyler, 436 U.S. 499, 513 n.2 (1978) (Stevens, J., concurring).

130 See, e.g., Michigan v. Tyler, 436 U.S. 499, 513-14 (1978) (Stevens, J., concurring); Marshall v. Barlow's, Inc., 436 U.S. 307, 328 (1978) (Stevens, J., dissenting).

131 Justice Stevens has adopted the position that the warrant clause does not imply a general preference for warrants. Marshall v. Barlow's, Inc., 436 U.S. at 327-28. This does not mean that a warrant is never required; to be reasonable, a search may have to be conducted pursuant to a valid warrant. Id. at 328 .

138436 U.S. 307, 328 (1978) (Steveng, J., dissenting).

133 Occupational Safety and Health Act of 1970, \& 8(a), 29 U.S.C. $\S 657(a)$ (1976). This 
The case is typical of the distinctive fourth amendment problems raised by the enforcement of health and safety regulations after Camara and See. The majority, relying on Camara, held that OSHA inspectors do not have the right to enter and inspect the premises of nonconsenting employers without a search warrant. ${ }^{134}$ The Court rejected the contention that OSHA inspections fall within one of the "recognized exceptions" to the warrant requirement. ${ }^{135}$ But lest this ruling make the Act unenforceable, the Court also held that the probable cause required to obtain the warrant was merely the showing that "reasonable legislative or administrative standards" 136 were followed in undertaking the search, rather than specific evidence that a violation existed. ${ }^{137}$ Such a warrant requirement, according to the majority, would still "provide assurances from a neutral officer that the inspection is reasonable under the Constitution, is authorized by statute, and is pursuant to an administrative plan containing specific neutral criteria."138

Justice Stevens advanced two separate theories in dissent. $\mathrm{He}$ noted that the fourth amendment has two distinct clauses and focused on the first: "[T] gory of warrantless searches authorized by the statute is 'unreasonable' within the meaning of the first Clause."139 Contrary to the majority, Justice Stevens concluded that regulatory OSHA inspections fall within the category of searches that, although not meeting the probable cause requirements of the warrant clause, are "reasonable" searches. The Justice's second argument, derived from his understanding of the intent of the framers of the fourth amendment, ${ }^{140}$ was that warrants issued on less than a showing of particularized probable cause are inconsistent with the principles underlying the amendment.

Justice Stevens offered several arguments for the reasonable-

section of the Act authorizes warrantless inspections of business premises.

134 436 U.S. at 325.

15s Id. at 313-14 (distinguishing United States v. Biswell, 406 U.S. 311 (1972) and Colonnade Catering Corp. v. United States, 397 U.S. 72 (1970)). The Court noted that OSHA inspections, unlike those in Biswell and Colonnade, do not apply solely to industries which, because of a "history of government oversight," have "no reasonable expectation of privacy." 436 U.S. at 313.

${ }^{138} 436$ U.S. at 320 (quoting Camara v. Municipal Court, 387 U.S. 523, 538 (1967)).

${ }^{137} 436$ U.S. at 320-22. See generally LaFave, supra note 115.

138 436 U.S. at 323 (footnote omitted).

139 Id. at 326 (Stevens, J., dissenting).

140 Justice Stevens quoted J. LANDYNSKI, supra note 111, at 19, and T. TAYLOR, supra note 128 , at 41 , to support his assertion that the framers were primarily concerned with the dangers of the general warrant, not with the threat of warrantless searches. 436 U.S. at 32728. 
ness of OSHA's warrantless inspections. First, he said, the Court should defer to Congress's determination that warrantless searches were essential to the enforcement of OSHA's safety regulations. ${ }^{141}$ Second, the Justice argued that the majority's requirement of an administrative warrant supported only by a general showing of conformity with the statutory scheme, although adding a burden to the government's enforcement task, offered little or no protection against arbitrary searches. Rather, the majority's "new-fangled inspection warrant," he said, is "essentially a formality" since the inspector need neither have nor show any cause to believe that violations of OSHA exist in an employer's plant. ${ }^{142}$ Third, Justice Stevens asserted that Barlow's was indistinguishable from other business searches falling within the category excepted from the warrant requirement. ${ }^{143}$ In his view, businesses subject to the provisions of OSHA, like those subject to liquor or firearms regulation, "are required to be aware of and comply with regulations governing their business activities."144 Justice Stevens's final argument reflected his conclusion that the work areas subject to inspection in Barlow's were in no sense confidential and that the privacy interest of the employer was simply not of the same magnitude as that traditionally protected by the amendment. ${ }^{145}$

Justice Stevens's second line of reasoning was framed as a criticism of the majority's "warrant preference."146 Arguing that the Framers intended the warrant clause of the fourth amendment as a procedural safeguard against the evils of the general warrant, Justice Stevens concluded that any warrant issued on less than particularized probable cause is contrary to the purpose of the amendment. The Justice, unlike the majority, recognized that the scope of gov-

14436 U.S. at $330-31$ \& n.6.

142 Id. at 337 .

143 In United States v. Biswell, 406 U.S. 311 (1972), the Court upheld warrantless searches of firearm dealers under the Gun Control Act of 1968. The Court deferred to the judgment of Congress that the public interest required such searches in spite of the invasion of the privacy of the businesses involved. Id. at 317. On a somewhat different rationale, the Court held in Colonnade Catering Corp. v. United States, 397 U.S. 72 (1970), that Congress's broad, longstanding power to regulate liquor justified warrantless searches.

i" 436 U.S. at 338.

is Id. Justice Stevens distinguished Camara and See on this basis. Camara, he argued, was different because it involved a residence, which is entitled to the highest degree of privacy; See did involve commerical premises, but the inspection in that case involved locked premises and a statute authorizing far broader search powers than the OSHA provisions at issue in Barlow's. Id. n.9. Moreover, he argued, Biswell and Colonnade were evidence that "the doctrine of stare decisis does not compel the Court to extend [Camara and See] to govern today's holding." Id.

II' Id. at 328. Justice Stevens was reiterating a criticism of administrative warrants expressed by Justice Frankfurter in Frank and Justice Clark in Camara. 
ernmental intrusions now restricted by the amendment far exceeds those within the purview of the amendment at the time of its ratification. Thus, Justice Stevens concluded:

[W] should not dilute the requirements of the Warrant Clause in an effort to force every kind of governmental intrusion which satisfies the Fourth Amendment definition of a "search" into a judicially developed, warrant-preference scheme.

Fidelity to the original understanding of the Fourth Amendment, therefore, leads to the conclusion that the Warrant Clause has no application to routine, regulatory inspections of commercial premises. ${ }^{147}$

Notwithstanding the sharply divergent views of the majority opinion and Justice Stevens's dissent, in one sense both sides of the debate in Barlow's agreed that the question whether a warrant is required for a given search depends upon reasonableness-specifically a weighing of the public interest against the private interest protected by the fourth amendment. Both majority and dissent agreed that certain administrative searches are justified even without particularized probable cause to search. Under its reasonableness standard, the majority would permit lowering the probable cause showing for the issuance of a warrant, but would require warrants for their protecting and validating features. Justice Stevens would not allow a warrant to issue absent probable cause, but would allow warrantless searches if other safeguards are present.

The peculiar facts of Barlow's somewhat undercut the force of the differences between Justice Stevens and the majority. The case arose through the refusal of respondent to admit an OSHA inspector without a warrant. ${ }^{148}$ The inspector did not attempt to enter the premises without some court sanction. Indeed, OSHA regulations provided that if an employer refused entry, the inspector should report to his area director, who would proceed, if necessary, by obtaining a court order to admit. ${ }^{149}$ That procedure was followed in Barlow's. The OSHA regulations thus arguably provided procedural protections far superior to those required by the Court's construction of the warrant clause. Yet the Secretary of Labor specifically declined to rely on these regulations to defend OSHA's search authority, and the Court expressed no opinion whether they would satisfy the requirements of the fourth amendment. ${ }^{150}$

117 Id. at 328.

1 is Id. at 310 (majority opinion).

11929 C.F.R. \& 1903.4 (1978). See 436 U.S. at 317 n.12.

tso 436 U.S. at 325 n.23. 
Thus, when Justice Stevens argued that the majority's administrative warrant "adds little to the protections already afforded by the statute and pertinent regulations," 151 he failed to answer the issue addressed by the majority. Assuming that the majority, like Justice Stevens, would consider the regulations in force adequately protective of fourth amendment rights, there remains little practical difference between them. The only realistic difference is that employers who know that they have the right to demand a warrant may be less likely to cooperate with the unpopular OSHA inspectors than those who are led to believe that OSHA has a right to entry without warrant. Fear of widespread noncooperation may have been the principal motivating factor in the OSHA litigation strategy and the opinion of Justice Stevens. ${ }^{152}$

Although there may be few practical differences between the two views in this case, there are two advantages to Justice Stevens's approach. First, it does not "dilute" the probable cause requirement. As he argued in his dissent, the fourth amendment's limitation on warrants was specifically designed to prevent the abuse of the general warrant. ${ }^{153}$ If courts begin to adjust the probable cause standard according to their views of the needs of the case, its value in cases where it is genuinely applicable may be eroded. ${ }^{154}$ Second, the reasonableness requirement gives the courts great flexibility to accord practical procedural protections to persons who are the objects of searches. Administrative warrant proceedings are ex parte, and thus are limited to ensuring that the given search comports with the general legislative or administrative searching plan. They may be costly to the agency, but useless to the citizen. The purposes served by the inspection warrant- "to inform the employer that the inspection is authorized by the statute, to advise him of the lawful limits of the inspection, and to assure him that the person demanding entry is an authorized inspector"155 — can be satisfied just as well or better by other procedural protections imposed under a reasonableness requirement. ${ }^{156}$

131 Id. at 332 (Stevens, J., dissenting).

132 See id. at 330.

135 See note 140 supra.

134 See, e.g., Almeida-Sanchez v. United States, 413 U.S. 266, 275 (1973) (Powell, J., concurring); Davis v. Mississippi, 394 U.S. 721, 727 (1969). See also White, The Fourth Amendment as a Way of Talking about People: A Study of Robinson and Matlock, 1974 Sup. Cr. Rev. 165, 176-84 (discussing the policy of particularity and its apparent abandonment in Camara).

iss 436 U.S. at 332 (Stevens, J., dissenting).

150 A scheme like the OSHA regulations might govern the time, manner, or extent of the search, as well as the notice given to the object of the search. It might also provide for a 
The question inherent in Justice Stevens's approach in Barlow's is how to devise a standard for distinguishing between those searches that require a warrant in order to be reasonable and those that do not. The Justice's brief concurring opinion in Michigan v. Tyler ${ }^{157}$ illustrates, in a different context, his approach to this problem of defining the relative roles of the reasonableness and warrant clauses. Tyler involved a series of inspections at the scene of a fire that officials suspected had been deliberately set. The majority held that a warrant to search the premises was unnecessary so long as the search was more or less a part of the fire-fighting itself, but that an "administrative warrant"158 would be required for reentry once the exigent circumstances ${ }^{159}$ were removed. Once the authorities come to believe that some wrongdoing has taken place, the Court said, their search for evidence to be used in a criminal prosecution is subject to the usual requirement of proof of probable cause.

Justice Stevens agreed with the majority that a warrantless search was reasonable during the exigent circumstances because of "a special enforcement need." ${ }^{160}$ Departing from the majority, however, he said that a subsequent reentry should be governed by a reasonableness standard rather than by the Court's standard for administrative warrants. Rather than issue an administrative warrant based on less than particularized probable cause, Justice Stevens would instead impose the requirement that the fire authorities give fair notice of the impending search. While Justice Stevens agreed with the majority that a search of fire-damaged premises to determine the cause of a fire is a reasonable exercise of state power, he argued that, absent "probable cause to believe a crime has been committed," issuing a warrant for the search would both violate the "requirements of the Warrant Clause" and sanction a search with intrusive qualities totally unjustified by the law enforcement need supporting it. ${ }^{181}$

The need for some procedural protections can be met, in his

procedure to challenge the search before it is undertaken, if there is no need for an immediate or surprise search. See also LaFave, supra note 115, at 32-33 (procedure for prior challenge has long been part of civil administrative search procedure in England).

157436 U.S. 499, 512 (1978) (Stevens, J., concurring in part and concurring in the judgment).

13s See id. at 506 n.5 (majority opinion).

159 The judgment that exigencies justify a warrantless entry is made under the reasonableness clause. See id. at 509-10. The majority held, $i d$. at 510-11, and Justice Stevens agreed, $i d$, at 513 n.3 (Stevens, J., concurring), that the exigent circumstances extended beyond the actual firefighting to a search at the time of the fire and to a reentry several hours later when daylight returned.

${ }^{160}$ Id. at 513 n.3 (Stevens, J., concurring).

18s Id. at 513-14. 
analysis, by holding that the search is unreasonable unless accompanied by notice of the inspection. Treating the problem as one of reasonableness rather than warrantlessness enabled Justice Stevens to replace the ritualistic requirement of an ex parte warrant hearing with a genuine protection of privacy in the form of notice. Such an approach avoids the "abrupt and peremptory confrontation between sovereign and citizen" that results when the state, under the authority of a warrant, may make a forced and unannounced entry. ${ }^{182}$ The majority's position in Tyler illustrates the danger, which Justice Stevens noted in Barlow's, that a reduced probable cause requirement for administrative searches may result in intrusive searches unjustified either by probable cause to suspect illegality or by exigent circumstances or "pressing" enforcement needs. ${ }^{163}$

\section{B. The Requirement of Probable Cause: Third-Party Searches}

Both Justice Stevens and the majority set stricter standards for a lawful search when that search is conducted pursuant to a criminal investigation. The majority approaches probable cause with a sliding scale: as the evidence of crime grows, an "administrative warrant" may no longer be sufficient and a search may be conducted only after a showing of particularized probable cause. ${ }^{164}$ For Justice Stevens, too, "reasonableness" will generally not justify a particular search pursuant to a criminal investigation ${ }^{165}$ - here a warrant based on a high standard of probable cause is needed. It might thus appear that the two sides disagree only about the manner of controlling administrative searches. Yet, a bifurcated reading of the fourth amendment-normally insigificant in analyzing searches pursuant to criminal investigation-is meaningful for searches for ordinary evidence (not fruits or instrumentalities of crime or contraband) in the possession of an innocent third party. Justice Stevens's dissent in Zurcher $v$. Stanford Daily ${ }^{166}$ exemplifies the importance of the Justice's theory of the fourth amendment to cases involving searches for "mere evidence."

In Stanford Daily, five Justices upheld the validity of a search warrant directed at The Stanford Daily, a student newspaper, to obtain photographic evidence of a violent demonstration that had taken place on the Stanford University campus. ${ }^{167}$ Earlier editions

112 Id. (footnote omitted).

wi Id. at 514 n.4.

III See Zurcher v. Stanford Daily, 436 U.S. 547, 565 (1978).

ics Barlow's, 436 U.S. at 326.

II 436 U.S. 547, 577 (1978) (Stevens, J., dissenting).

wo7 Justice White, writing for the Court, was joined by Chief Justice Burger and Justices 
of The Daily had indicated that the paper might possess such evidence. The case has attracted great attention because of the first amendment questions raised by police or judicial intrusion into journalistic source materials. Like the majority in the case, however, Justice Stevens concentrated on the fourth amendment aspects, treating the newspaper in the same way as he would any other innocent third-party object of a search.

The majority rejected lower court decisions that held the search of an innocent person's files unconstitutional absent a showing that a subpoena duces tecum would not have been honored. The Court labelled these decisions a "sweeping revision of the Fourth Amendment" and noted that there was no federal precedent for any distinction between culpable and innocent objects of search warrants. ${ }^{168}$ If anything, earlier cases ${ }^{169}$ indicated that more protection would be given to the person suspected of a crime. Since "probable cause" for a search warrant and "probable cause" for an arrest are two different things, the innocence of The Daily was ultimately immaterial.

Justice Stevens disagreed. He argued that third-party evidentiary searches present serious issues of intrusion into privacy-issues that are not present in other searches and were not considered by the framers of the amendment-that require careful analysis of the appropriate probable cause requirement. ${ }^{170}$ The consequences to the searched party are great: the searcher may gain access to information that would not be obtained if the search were challengeable in advance, the searcher may gain access to unrelated private material, and the occurrence of the sudden search may blacken the search victim's reputation. ${ }^{171}$ Unlike searches for fruits or instrumentalities of crime and contraband, where the probable cause to believe the subject of the search possesses the sought-after objects suggests participation in criminal activity and consequently would support the need for sudden and unannounced search, the third-party search for mere evidence cannot be so justified. ${ }^{172}$ Since

Blackmun, Rehnquist, and Powell (who also filed a concurring opinion, $i d$. at 568).

16" Id. at 554 \& n.4 (majority opinion).

I' Camara v. Municipal Court, 387 U.S. 523, 534-35 (1967); Frank v. Maryland, 359 U.S. 360,365 (1959).

170436 U.S. at 577 (Stevens, J., dissenting). Justice Stevens observed that the problem in Stanford Daily resulted from the "profound change in Fourth Amendment law" wrought by Warden v. Hayden, 387 U.S. 294 (1967). 436 U.S. at 577.

171436 U.S. at $578-80$.

172 Justice Stevens argued that "[m]ere possession of documentary evidence" does not persuasively demonstrate "that the custodian is guilty of any wrongdoing or that he will not honor a subpoena or informal request to produce [the evidence]." Id. at 581. Moreover, the Justice argued that seizure of such evidence would constitute a constitutional deprivation of 
"[t]he only conceivable justification for an unannounced search of an innocent citizen is the fear that, if notice were given, he would conceal or destroy the object of the search,"173 Justice Stevens would not permit the issuance of a warrant unless the warrant application "demonstrates the need for an unannounced search by force."174

Certain language in Justice Stevens's dissent in the Stanford Daily case seems to confuse the doctrinal basis for his earlier conclusions that the lack of particularized probable cause in administrative warrants renders them unconstitutional. In Barlow's and Tyler, he had distinguished between the reasonableness of a search procedure and the probable cause for a belief that evidence (or a violation) would actually be found in a particular location. Here there was clearly probable cause in this limited sense, but issuance of a warrant was not reasonable since there was insufficient reason to think that an innocent third-party would refuse to produce the evidence in response to a subpoena and would destroy it instead.

Justice Stevens appeared to base that conclusion on the very reasoning he rejected in Barlow's: that the validity of a warrant ultimately rests upon its reasonableness. "[I]f nothing said under oath in the warrant application demonstrates the need for an unannounced search by force, the probable cause requirement is not satisfied."175 This language can be read to imply that the probable cause requirement is a requirement that a magistrate be satisfied of the search's reasonableness. In fact, he adopted a formulation of the reasonableness requirement that precisely parallels that understanding of probable cause: "[T] he standard of reasonableness embodied in the fourth amendment demands that the degree of justification match the degree of intrusion." 176 Such reasoning appears inconsistent with the Justice's insistence upon particularized probable cause in the administrative warrant cases even though that particularized finding is not essential to the search's reasonableness. But his language does not imply that the reasonableness requirement is exclusive; rather, in making the determination to issue a warrant, the magistrate must demand both a demonstration of probable cause to believe that the evidence will be found and that the contemplated intrusion is justified by the law enforcement need

liberty entitling the citizen to either "[n]otice and an opportunity to object" or "strict compliance [by the law enforcement officials] with the Fourth Amendment." Neither requirement was met, according to Justice Stevens, by the search in question. Id. at 581-82.

its Id. at 581.

17 Id. at 583.

irs Id.

${ }^{176}$ Id. at 578 (quoting Berger v. New York, 388 U.S. 41, 69 (Stewart, J., concurring in the judgment)). 
it is intended to serve. In the usual search case, probable cause will satisfy both requirements, but in the case of evidentiary searches of innocent third-parties, additional protection is required. This protection is provided by the requirement of reasonableness in a bifurcated analysis of the fourth amendment. ${ }^{177}$

As a practical matter, Justice Stevens's presumption that third-parties will not destroy evidence may be incorrect. As the majority in Stanford Daily pointed out, search warrants are often employed early in the investigation, at a time when the guilty cannot be distinguished from the innocent: "The seemingly blameless third party . . . may not be innocent at all; and if he is, he may nevertheless be so related to or sympathetic with the culpable that he cannot be relied upon to retain and preserve the articles that may implicate his friends." 178 Moreover, as may be the case with newspapers, the innocent third party may view his relationship to the police as adversarial. ${ }^{779}$ These incentives not to cooperate would be, at best, difficult to prove in a probable cause hearing. In effect, the citizen's good will would be the only real guarantee that the investigation not be frustrated. ${ }^{180}$

Justice Stevens's presumption is not irrebuttable, however. A probable cause hearing, he might respond, is the place to rebut it. Law enforcement goals, moreover, cannot always be fulfilled in a manner consistent with fourth amendment protections. The amendment is, fundamentally, a choice to prefer individual privacy over completely effective law enforcement. ${ }^{181}$ A dragnet search of citizens frequenting high crime areas is clearly unconstitutional, ${ }^{182}$ although it may result in the discovery of contraband or the apprehension of fugitives. The decision was made to permit warranted searches only when the need for the search can be demonstrated to a neutral magistrate. Despite the possibility that it may prevent completely effective law enforcement, Justice Stevens's position seems consis-

${ }^{177}$ See generally Weinreb, supra note 110, at 69-72. Professor Weinreb points out that a bifurcated fourth amendment analysis would permit courts to distinguish and make allowances for the various "degrees of privacy" invaded by a search warrant. Professor Weinreb's discussion focused upon searches for "mere evidence," precisely the problem area Justice Stevens's bifurcated analysis in Stanford Daily is intended to deal with.

$17 \times 436$ U.S. at 561 (majority opinion).

17 In Stanford Daily, for example, the respondent newspaper had an announced "policy of destroying any photographs that might aid prosecution of protestors." Id. at 568-69 n.1 (Powell, J., concurring).

${ }^{180}$ As the majority noted, even if the third party acts in good faith, the delay involved in employing a subpoena duces tecum may enable the real culprit, who may have access to the property, to take or destroy it. Id. at 561 (majority opinion).

ist See Weinreb, supra note 110, at 47.

${ }^{132}$ See generally Collier v. Miller, 414 F. Supp. 1357 (S.D. Tex. 1976). 
tent with that constitutional decision in view of the increased intrusiveness and opportunity for abuse accompanying third-party evidentiary searches and the reduced urgency of searches in that context.

\section{Justice Stevens and the Dilemma of Fourth Amendment Doctrine}

Justice Stevens's fourth amendment opinions represent an attempt to adapt the constitutional language to search and seizure cases outside the scope of the original intent of the amendment's framers. It is at once an effort to preserve traditional understanding of the amendment and to adapt and reformulate its doctrine to new contexts. By "abandoning" the warrant as the sole determinant of constitutionally permissible searches, the Justice is in effect saying that warrants should be confined to the functions they have traditionally served. ${ }^{183}$ With regard to routine administrative inspections intended to maintain health and safety regulations, he believes the fourth amendment permits reasonable, though warrantless, searches. In those cases in which a governmental search is directed against presumably innocent third parties for ordinary documentary evidence, Justice Stevens would not abandon the warrant, but would demand a higher than ordinary standard of probable cause.

Justice Stevens has been particularly responsive to the stress placed on prior fourth amendment doctrine by the full application of the amendment to noncriminal, administrative searches. ${ }^{184}$ Such searches are difficult to accomodate in a theoretical framework that protects against searches by emphasizing the necessity for warrants ${ }^{185}$ and demands a particularlized showing of probable cause. ${ }^{188}$ In Barlow's, the Court resolved the dilemma by reducing the particularity of justification required to obtain a warrant to search. Justice Stevens's distinctive approach-evaluating administrative searches under the reasonableness clause of the amendment-recognizes the qualitative difference between such searches and the governmental intrusions that have historically been the concern of the fourth amendment. The fundamental purposes of the amendment-to safeguard citizens against both physical intrusion

18 See Marshall v. Barlow's, Inc., 436 U.S. 307, 328 (1978) (Stevens, J., dissenting).

14 Prior to Camara the Court had treated civil administrative searches as outside the scope of full fourth amendment protection. See Frank v. Maryland, 359 U.S. 360 (1959); text and notes at notes 114-117 supra.

1ss See United States v. Rabinowitz, 339 U.S. 56, 72 (1950) (Frankfurter, J., dissenting) (exceptions to the warrant requirement are rooted in necessity).

is See, e.g., Carroll v. United States, 267 U.S. 132 (1925). 
and "the seizure of one's possessions and their use against one"187-are distant from the concerns engendered by civil searches to enforce health and safety regulations. Unlike searches occurring during a criminal investigation, which have as their object the prosecution of a citizen for a crime, administrative searches are generally not intended to be part of the criminal process; at least the justification offered in support of such searches is rarely enforcement of the criminal law.

It is arguable that in civil administrative searches the primary function of the fourth amendment is protection against physical intrusion. ${ }^{188}$ The concern with subsequent use of the evidence seized-one concern that justifies a strict application of the warrant requirement-may be absent. To the extent that protection of privacy is in fact the primary interest served by the fourth amendment in the context of administrative searches, Justice Stevens's approach provides a theoretically cleaner method of protecting this interest than that employed by the majority. ${ }^{189}$ The analysis of such searches is clearly distinguished from that of criminal investigatory searches. The judicially authorized warrant is preserved as a prohibition of general criminal searches. That role is emphasized by analyzing any search justified by a generalized need under the first clause of the amendment, thus avoiding both a bifurcated conception of the function of warrants in fourth amendment theory and some of the difficulties of distinguishing between searches that re-

187 White, supra note 154, at 213. See also Frank v. Maryland, 359 U.S. 360 (1959); Boyd v. United States, 116 U.S. 616, 630 (1886); Entick v. Carrington, 19 How. St. Trials 1030 (1765). But see Barrett, Personal Rights, Property Rights, and the Fourth Amendment, 1960 SuP. CT. Rev. 46; Comment, State Health Inspections and "Unreasonable Search": The Frank Exclusion of Civil Searches, 44 MinN. L. Rev. 513 (1960).

iss See, e.g., Camara v. Municipal Court, 387 U.S. 523, 530 (1967). Of course, when fines or other penalties may be imposed for regulatory violations discovered in the course of an administrative search, the citizen's interest has a self-protective as well as a privacy component. It may be difficult to justify differing treatment for administrative searches when they may lead to the imposition of penalties. The problem may be ameliorated by affording the citizen an opportunity to comply with the civil regulations before penalties are imposed. In Michigan v. Tyler, 436 U.S. 499 (1978), the Court confronted a similar problem of identifying the point at which an adminstrative search for the cause of a fire becomes a criminal investigation, necessitating a warrant based upon particularized probable cause.

is Justice Stevens does not necessarily approve of administrative searches; he appears instead to be willing to defer to Congress. "While one may question the wisdom of pervasive governmental oversight of industrial life, I decline to question Congress' judgment that the inspection power is a necessary enforcement device in achieving the goals of a valid exercise of regulatory power." 436 U.S. at 339 (Stevens, J., dissenting) (footnote omitted). It is difficult to believe, however, that Justice Stevens would accord the same deference to Congress's decision to conduct warrantless searches in other contexts. When an investigation uncovers sufficient evidence of a particular criminal violation, the investigator would be required to obtain an ordinary probable cause warrant to continue his inquiry. 
quire warrants and those that do not.

Justice Stevens's approach is generally sensible. His careful distinction between the two clauses of the fourth amendment and his reliance on the historical motivation for the amendment ${ }^{190}$ leads him to a jurisprudence that is more adaptable to the various circumstances in which the modern state confronts the privacy of the citizen. His willingness to give content to the reasonableness standard beyond the often formal requirement of a warrant offers hope for more practical protection of individuals in situations not conforming to the traditional search warrant paradigm. His insistence on preserving the particularized character of the probable cause determination may prevent erosion of that protection against warrant abuse. Although Justice Stevens has written few opinions in this area, and none for the majority, in his dissents and brief concurrence may be found the basis for a principled and workable fourth amendment approach.

\section{Procedural Due Process}

The procedural due process analysis developed by the Burger Court, described as a "protected-interest" analysis, ${ }^{191}$ is designed to achieve a sensible accommodation of the individual's rights and the government's power to act. It involves two separate inquiries. ${ }^{192}$ First, the court must determine whether the interest affected by the particular governmental activity complained of falls "within the contemplation of the 'liberty or property' language of the fourteenth amendment." 193 This determination depends upon the nature of the interest at stake, rather than its weight. ${ }^{194}$ Second, if the interest invaded is protected by the fourteenth amendment, the court must

in Although Justice Stevens's historical analysis appears to be in accord with at least one fourth amendment scholar, see T. TAYLOR, supra note 128, the historical evidence does not unambiguously support his entire fourth amendment theory. For example, Professor Landynski, whom Stevens cites in support of his assertion that protection against general warrants was the "principal stimulus" for the amendment, 436 U.S. at 327 , concludes on the basis of his historical analysis that treating the reasonableness clause as an independent justification for a search is inconsistent with the intended meaning of the amendment. J. LANDYNSKI, supra note 111, at 43. Justice Stevens also fails to take note of the confusion surrounding the adoption of the final language of the amendment. See N. LASsoN, supra note 124 , at $100-03$.

10I The term derives from the Court's statement that the right to a hearing is paramount when "protected interests are implicated." Board of Regents v. Roth, 408 U.S. 564,569 (1972).

192 In this respect, the Burger Court's approach to procedural due process is in marked contrast to that employed by the Court prior to 1970 . Under the earlier due process analysis, a one-step process was applied to determine the requirements of procedural due process. See L. TRIBE, supra note $12, \S 10-8$, at 507 .

"13 Morrissey v. Brewer, 408 U.S. 471, 481 (1972).

is' Board of Regents v. Roth, 408 U.S. 564, 571 (1972). 
determine whether the procedures that accompanied the invasion are sufficient to withstand constitutional scrutiny. This inquiry requires assessment of the "weights of the particular interests involved." 195 Both stages of the protected interest analysis require close attention to the facts of the cases and precise identification of the real interests implicated.

Justice Stevens generally has adhered to this doctrinal framework, but certain of his opinions reflect variations in emphasis on the elements of the due process inquiry. He has departed from his fellow Justices regarding the scope of protected interests and both the degree of process required and the time at which such process is due.

\section{A. Due Process and Capital Punishment: Justice Stevens's Protected Interest Analysis}

Justice Stevens's use of the balancing required by the second stage of the protected-interest analysis is demonstrated by his majority opinion in Gardner $v$. Florida, ${ }^{196}$ upholding the petitioner's due process challenge to a sentence of death. The petitioner had been convicted of first-degree murder by a Florida jury. The jury had found that mitigating circumstances outweighed aggravating circumstances and recommended a life sentence. The judge nevertheless imposed the death penalty, stating that his decision was partly based on undisclosed information contained in a presentence investigation report. Neither the petitioner nor the state requested to see the report, and the judge failed to offer them an opportunity to examine it. Petitioner thus had not responded to or challenged the information relied on by the judge.

Justice Stevens weighed each of four interests asserted by the state in using confidential investigatory reports for sentencing. ${ }^{197}$

103 Id. at 570. The second-stage inquiry involves three factors: the private interest affected by the challenged governmental action, the value of the procedures employed and proposed, and the government's interest in the challenged practices. See Mathews v. Eldridge, 424 U.S. 319, 335 (1976). See generally Mashaw, The Supreme Court's Due Process Calculus for Administrative Adjudication in Mathews v. Eldridge: Three Factors in Search of a Theory of Value, 44 U. CHI. L. REv. 28 (1976).

196430 U.S. 349 (1977). Justice Stevens was joined by Justices Stewart and Powell. Chief Justice Burger concurred in the judgment, and Justices White and Blackmun wrote separate concurring opinions. Justices Brennan, Marshall, and Rehnquist dissented, each writing a separate opinion.

107 Justice Stevens first concluded that the case was not controlled by a prior Supreme. Court decision. Williams v. New York, 337 U.S. 241 (1949), upheld a captial sentence predicated partly on a confidential presentence investigation report. Justice Stevens distinguished the case on two grounds. First, in Williams, the judge had read the important sections of the report to the parties, who thus had an opportunity to challenge false or misleading informa- 
First, the state claimed that assurance of confidentiality of presentence reports was essential to enable the state to obtain the information from sources who might not want their opinions made public. ${ }^{198}$ Justice Stevens recognized that a confidential report might provide "the judge with a better basis for his sentencing decision." 199 But the Justice considered this interest outweighed by the danger that "the information accepted in confidence may be erroneous, or may be misinterpreted." ${ }^{200} \mathrm{He}$ determined that the system cannot risk tipping the scales in favor of the death penalty through unchallenged, hence possibly unreliable, information.

Second, the state suggested that full disclosure of presentence reports would unduly delay sentencing proceedings. ${ }^{201}$ Justice Stevens found that the risk of delay was overstated since such reports are presumably accurate and judges can avoid delay by simply ignoring disputed material. More importantly, he reasoned that ascertaining the truth of disputed material critical to the question of life or death would be worth the time spent.

Third, the state claimed that full disclosure would impede rehabilitation of the defendant because such reports often include psychiatric and psychological evaluations. ${ }^{202}$ Justice Stevens responded that this argument did not justify withholding the information from defense counsel, pointing out that rehabilitation is irrelevant to a defendant facing execution. ${ }^{203}$ Although this response may not entirely dispose of the state's argument in the case in which the defendant is exposed to the information, either by his attorney or in court, and is later sentenced to prison, Justice Stevens seems correct in finding this state interest outweighed by the interest of the defendant facing possible execution.

Finally, the state reasoned that the discretion of trial judges should be trusted even when they base their decisions on secret information. ${ }^{204}$ Justice Stevens found this argument to be foreclosed by decisions subjecting the capital sentencing process to close appellate review to guarantee rationality and consistency ${ }^{205} \mathrm{He} \mathrm{em}$ -

tion. Second, at the time Williams was decided the Court had recognized no significant constitutional difference between the death penalty and lesser punishments, and had not decided that sentencing procedures are governed by the due process clause.

103430 U.S. at $358-59$.

i" Id. at 359 .

200 Id.

201 Id.

202 Id. at 360.

203 Id.

201 Id.

2005 Id. at 360 n.11. See Proffitt v. Florida, 428 U.S. 242 (1976) (upholding Florida's capital punishment statute subject to strict procedures, including meaningful appellate review). 
phasized the value of adversary participation of counsel in the process of evaluating evidence and the necessity of a record for the constitutionally mandated appellate review. Accordingly, Justice Stevens found that the asserted state interests failed to outweigh petitioner's interest in life and, therefore, that the petitioner had been denied due process of law. The sentence was vacated and the case remanded.

In Gardner, Justice Stevens attempted to dispel the confusion concerning the death penalty by employing the procedural due process clause, rather than the eighth amendment, to govern the procedures for its imposition. Prior to Gardner, the Court had adjudged challenges to both the substance and the procedure of capital punishment under the rubric of the eighth amendment's prohibition of cruel and unusual punishments. ${ }^{206}$ The eighth amendment can, however, quite plausibly be limited to protection against certain types of punishment: against the "unnecessary and wanton infliction of pain." ${ }^{207}$ The language of the fourteenth amendment, on the other hand, directly concerns process, and thus should be read to govern the adequacy of procedures surrounding capital punishment. ${ }^{208}$ There is, moreover, no convincing reason to continue to adhere to the eighth amendment framework when procedure is the only question. Under the due process clause, the Court is free to examine the adequacy of the procedures under all the relevant circumstances. Eighth amendment analysis, on the other hand, is directed to four basic hallmarks of "cruel and unusual punishment": unusual severity, probability of arbitrariness, rejection by contemporary society, and penal purpose. ${ }^{209}$

Justice White, concurring in Gardner, ${ }^{210}$ objected to the em-

200 This may perhaps be attributable to the fact that Furman v. Georgia, 408 U.S. 238 (1972), the leading death penalty precedent, was decided under a grant of certiorari directed to the "cruel and unusual punishments" issue. Subsequently, in Woodson v. North Carolina, 428 U.S. 280 (1976), the Court applied the eighth amendment in a detailed examination of the procedures for invoking the death penalty, even though the legality of the penalty was not seriously in doubt, having been established in the companion case of Proffitt v. Florida, 428 U.S. 242 (1976). Use of the eighth amendment to govern sentencing procedure has been justified by interpreting the language prohibiting "unusual" punishments to mean punishment "wantonly and . . . freakishly imposed." Furman v. Georgia, 408 U.S. at 310 (1972) (Stewart, J., concurring).

${ }^{207}$ Gregg v. Georgia, 428 U.S. 153, 173 (1976). See also Estelle v. Gamble, 429 U.S. 97 (1976).

203 Even Justice Douglas, whose Furman concurrence is largely devoted to showing that the eighth amendment provides procedural guarantees against discriminatory treatment, seemed to admit that this argument could rest as well on the fourteenth amendment. See 408 U.S. at 241, 249, 255, 257 (Douglas, J., concurring).

see Furman v. Georgia, 408 U.S. 238, 282 (1972) (Brennan, J., concurring).

210430 U.S. at 362 (White, J., concurring). 
ployment of the fourteenth amendment as a procedural standard, apparently fearing that a holding based on the fourteenth amendment might not be confinable to capital punishment cases. But the Court has construed the due process clause in a flexible manner: the process required prior to the infliction of so extreme a punishment as death is not necessarily required in noncapital cases. ${ }^{211}$ Justice White's concern, therefore, seems unfounded, even if it is presumed undesirable to apply the due process clause to noncapital sentencing procedures.

By adopting a procedural due process analysis, Justice Stevens blunted the arguments of the dissenting Justices to his left and right. Justice Marshall took the position that the death penalty itself should be abolished because of the fundamental inadequacy of the procedures. ${ }^{212}$ Justice Stevens's position, in contrast, enabled the Court to direct its attention to the flaws in the procedure without invalidating the form of punishment. Justice Rehnquist argued that since the "Eighth Amendment relates to the character of the punishment, and not to the process by which it is imposed," there was no constitutional flaw in the capital sentence. ${ }^{213}$ Under the procedural due process analysis, it is more difficult to argue that the Court has no right to scrutinize the process employed by the sentencing court.

On its face, Gardner may have been an easy decision. ${ }^{214}$ The

211 "[N]ot all situations calling for procedural safeguards call for the same kind of procedure." Morrissey v. Brewer, 408 U.S. 471, 481 (1972).

212430 U.S. at 365 (Marshall, J., dissenting). Justice Marshall has consistently held that the death penalty is unconstitutional in all circumstances. Id.; Gregg v. Georgia, 428 U.S. 153, 231 (Marshall, J., dissenting); Furman v. Georgia, 408 U.S. 238, 314 (Marshall, J., concurring). In Gardner he argued that the inadequate review given the case by the Florida Supreme Court undermined the rationale for upholding Florida's death penalty. 430 U.S. at 365.

213430 U.S. at 371 (Rehnquist, J., dissenting). Justice Rehnquist apparently believed the plurality opinion to be based on the eighth amendment, as was Woodson v. North Carolina, 428 U.S. 280 (1976). His discussion of due process was limited to the remark that the sentencing procedures in question were "never previously held unfair under the Due Process Clause." 430 U.S. at 371.

214 It seems probable that Justice Stevens was less concerned with the procedural flaw upon which he based his decision than with certain troubling facts in the case. The importance to the petitioner of access to the presentence report may have been exaggerated: his counsel made no request at the time of sentencing to examine the full report or to be informed of its contents. 430 U.S. at 353 . Either the attorney considered the report inconsequential, or his failure to request access was an unethical attempt to provoke error.

Justice Stevens may have been motivated by facts in the record that strongly indicated that there existed the mitigating circumstances of extreme mental or emotional disturbance and incapacity to appreciate the criminality of the deed or to conform conduct to the requirements of the law. As Justice Marshall pointed out, the petitioner had been drinking virtually the entire day and night before the killing. After murdering his wife with a blunt instrument, 
trial court imposed the death penalty in utter disregard of the jury's recommendation of mercy and failed to set forth the reasons for the sentencing in the record. Justice Stevens's determination that such an apparently capricious result could not stand is not surprising. The Justice's use of the due process analysis in Gardner is, however, illustrative of his adherence to the "protected interest" framework. Although the case involved a particularly egregious deprivation, Justice Stevens nevertheless carefully considered each separate state justification for the procedure; in doing so, he achieved a proper result while preserving the Court's future flexibility to judge other death penalty procedures on their own merits.

\section{B. Restriction of the Scope of Procedural Due Process}

Although Justice Stevens, in Gardner, demonstrated a willingness to employ procedural due process analysis expansively, he has also apparently been sensitive to the possibility that the flexibility of the analysis might result in unacceptable judicial involvement in the intricacies of governmental processes. Not only might such involvement intrude upon the appropriate power of other governmental units, it might also mire the federal courts in trivialities to the detriment of their more important functions. ${ }^{215}$ In a series of opinions, the Justice has sought to limit the procedural effect of the due process clause by narrow interpretations at both stages of "protected interest" analysis: in some cases he has cut back on the breadth of interests protected, in others he has narrowly construed the type of process required.

1. Protected Interests. Bishop v. Wood ${ }^{216}$ is a prime example of Justice Stevens's narrow construction of the scope of "protected interests." Bishop concerned a North Carolina policeman who was discharged without a hearing. The city ordinance defining the policeman's tenure provided that he could be discharged if he failed to perform work up to the standard of his classification, or if he were negligent, inefficient, or unfit to perform his duties. ${ }^{217}$ The district court somehow interpreted this to mean that the policeman "held

petitioner slept with the dead body, and appeared not to realize she was dead the next morning. Id. at 369. Justice Stevens may have preferred to balance the procedural interests rather than to overturn the trial judge's odd factual determination that there were no mitigating circumstances.

215 This prospect has, on several occasions, caused the Court to constrict the scope of the procedural due process guarantee. See, e.g., Meachum v. Fano, 427 U.S. 215, 224-25 (1976); Paul v. Davis, 424 U.S. 693 (1976).

216 426 U.S. 341 (1976).

217 Id. at 344. 
his position at the will and pleasure of the city."218 The Fourth Circuit, en banc, split evenly on the issue. ${ }^{219}$ Justice Stevens, writing for a five-Justice majority, ${ }^{220}$ held that there was no deprivation of property or liberty, and hence no need to question the adequacy of the process.

Justice Stevens admitted that although the ordinance, on its face, might fairly be read as guaranteeing petitioner continued employment, 221 it might also be construed as granting no such right, but merely conditioning dismissal on the city's observance of specified police department procedures. Since the Justice found both readings plausible, and since the state courts had not construed the city ordinance, he deferred to the judgment of the district court, which he found "tenable," and held that the ordinance did not constitute a property entitlement. ${ }^{222}$ With respect to petitioner's purported liberty interest, the Justice reasoned that there would be no serious effect on petitioner's future employment prospects because the reasons for the discharge were kept confidential. Even if the asserted reasons for the discharge were false, Justice Stevens declined to find petitioner's liberty invaded. ${ }^{223}$

The stated reasons for Justice Stevens's conclusions in Bishop are easily faulted. The district court's interpretation of North Carolina law, on which the Justice relied, seems contrary to the language of the statute. Interpretation of state law by a federal court seems an inappropriate occasion for such deference. Moreover, Justice Stevens's argument that the confidentiality of the reasons for discharge protects the discharged policeman's future employment prospects is unrealistic in the world of police job-hunting, where prior employment experience is routinely investigated by prospective employers. ${ }^{224}$

Similar to Bishop is Justice Stevens's dissent in Codd $v$. Velger. ${ }^{225} \mathrm{~A}$ New York City police officer had been discharged, after an apparent suicide attempt, without a statement of reasons or a hearing. The majority, although willing to assume that the officer

${ }^{218}$ Id. at 345.

210 See id. at 343 n.3.

200 Justice Stevens was joined by Chief Justice Burger, and by Justices Stewart, Powell, and Rehnquist.

221426 U.S. at 345 .

22 Id. at $345-47$.

223 Id. at 349 .

224 See id. at 350 (Brennan, J., dissenting).

${ }^{225} 429$ U.S. 624, 631 (1977) (Stevens, J., dissenting). Justice Stevens's opinion is a dissent rather than a concurrence because, although agreeing with the majority that no liberty interest was invaded, he would have remanded the case on the claim of property deprivation. 
was "stigmatized" by the dismissal, rejected the claim on the ground that the officer failed to allege that the reasons for dismissal were false. ${ }^{228}$ Justice Stevens, however, argued that stigma had not been proved. He noted that the record was unclear about the precise nature of the adverse information in the officer's file. Even though the record showed that a subsequent employer fired the officer after seeing the information in the file, Justice Stevens did not reject the district court's dubious determination that the officer had failed to satisfy his burden of proving stigma on the basis of the dismissal. ${ }^{227}$

The Justice's position would place the potential plaintiff in a difficult position. In order to prove, as a matter of law, that employers would uniformly refuse to hire him, a discharged employee would have to suffer a lengthy period of unsuccessful job searching. ${ }^{228}$ Moreover, if, as Justice Stevens said in Codd, the requirement of fair procedure is unrelated to the merits of the particular case, it seems inconsistent to require that the discharged employee prove injury before his right to a hearing is vindicated. As in Bishop, Justice Stevens gave deference to the lower court judgment in spite of its implausibility, thereby restricting the scope of due process intervention in the personnel decisions of local governments.

2. Adequacy of Process. Justice Stevens's dissent in Memphis Light, Gas \& Water Division v. Craft, ${ }^{229}$ which focused on the adequacy of the process rather than the existence of a protected interest, suggests a more relaxed due process scrutiny of routine governmental actions. Petitioner Memphis Light, a public utility, was sued in connection with the termination of respondents' utility service. Respondents, customers of the utility, had been receiving two separate bills for the service. Believing that they were being billed

233 Id. at 627 (per curiam). Technically, it was unnecessary for the majority to reach the question whether the officer was "stigmatized" by his dismissal, because the case was disposed of on other grounds. Justice Stevens disputed the Court's novel theory that proper procedures need not be followed unless the plaintiff can allege-and possibly unless he can prove-that he was substantively wronged. He reasoned that "it is essential that fair procedure be followed for reasons that have nothing to do with the merits of the individual case." Id. at 636 (Stevens, J., dissenting).

227 "On this record, it cannot be said as a matter of law that prospective employers would reject respondent's attempts to explain this incident and would uniformly refuse to hire him." Id. at 638-39.

223 This seems to be a retreat from Wisconsin v. Constantineau, 400 U.S. 433, 437 (1971), in which the Court said, "[w] here a person's good name, reputation, honor, or integrity is at stake because of what the government is doing to him, notice and an opportunity to be heard are essential." Either Justice Stevens took an excessively deferential position toward the findings of the district court, or he must have intended to soften the effect of cases such as Constantineau.

436 U.S. 1, 22 (1978) (Stevens, J., joined by Burger, C.J., and Rehnquist, J., dissenting). 
twice for the same utility use, and unable to obtain a fully satisfactory response to their complaints, ${ }^{230}$ respondents paid only one bill. As a result, their service was terminated four times during the duration of their dispute with the utility. It was finally determined that respondents were not being "double-billed"; rather, the two bills covered different portions of their home, a converted duplex. ${ }^{231} \mathrm{~A}$ majority of the Court found that the termination of services was a deprivation of property without due process. 232

Justice Stevens accepted the majority's conclusion that there had been a deprivation of property, but denied that the utility's procedures offended due process. ${ }^{233}$ Examining the facts of the case, the Justice found that the respondents had been given timely notice of the termination and an opportunity to challenge it. Memphis Light had a policy of sending any customer a timely notice advising him that he must pay his bill by a certain date or face cut-off of services. The notice also requested the customer to contact the Credit and Collections Department if he had difficulty in paying the bill. In prominent figures, the notice listed a phone number where Memphis Light employees could be reached who would then direct customers to other officials authorized to resolve conflicts on a more permanent basis. Justice Stevens concluded from the facts of the case that the respondents met with responsible Memphis Light officials, but were unable to convince the officials that there had been a billing error. ${ }^{234}$

On a more general level, Justice Stevens discounted the majority's concern with health and safety consequences of the termination policy and found the procedures adequate protection for the customer's interest. The large numbers of terminations per month without customer complaints of danger to health, the utility's policy not to disrupt service when there is an illness in the home, and the ease with which a customer could avoid termination by paying his bill under protest convinced Justice Stevens that the termination procedures in use did not seriously threaten health or safety. ${ }^{235}$ The Justice rejected the majority's reasoning that the termination notice

220 There appears to have been a factual dispute between Justice Stevens and the majority about what sort of hearing respondents received. The majority concluded that Mrs. Craft's complaint was dealt with by an employee of "uncertain authority," "apparently without explanation or attempt at investigation." Id. at $16 \mathrm{n} .19$. Justice Stevens concluded from the record that "Mrs. Craft did meet with Division employees having adequate authority but simply failed to persuade any of them that there was any error in her bills." Id. at 24-25.

231 Id. at 24 n.5.

232 Id. at 22.

205 Id.

234 Id. at 25 .

23 Id. at 28-29. 
must include a description of methods available to protest a bill as resting "on a paternalistic predicate that I cannot accept." 236 Such information, he said, is necessary only in the "most unusual situations" 237 because the ordinary homeowner is capable of lodging a complaint on his own initiative, without an elaborate description of procedures.

The Justice also found that customers were adequately protected by available post-termination judicial remedies. He disputed the majority's contention that the sums of money involved were too small to justify bringing a lawsuit: if the loss was serious enough to be a constitutional deprivation, it could "hardly be too petty to justify invoking the aid of counsel or the judiciary." 238 More important, Justice Stevens reasoned, is the deterrent effect of potential damage actions, which "provides far more significant protection against an unjustified termination" than would the niceties of procedure and the vague requirement of "some kind of hearing" upon which the majority relied..$^{239}$

Justice Stevens's disagreement with the majority focused upon the weight to be given the individuals' interests implicated in the case. The majority was concerned with the risk that the available procedures might endanger customer health and safety; Justice Stevens responded that there was no realistic safety threat. The majority worried about the inability of the customer to understand or discover the procedures for challenging a bill; Justice Stevens emphasized that the respondents managed to obtain a hearing on their unusual complaint, and that the ordinary citizen is and must be capable of showing such initiative.

Although Justice Stevens criticized the majority for trivializing the notion of due process by its decision in Memphis Light, ${ }^{240}$ it is arguable that the Justice has set the threshold of due process protection too high. When the government provides essential services and induces significant reliance on the continued provision of those services, due process demands that they not be terminated unless the individual has a realistic opportunity to vindicate his rights. Justice Stevens concluded that the opportunity in Memphis Light was in fact a realistic one. This conclusion was not the result of a balancing of the individual's interest against that of the state, but was based on the Justice's own conviction that "a homeowner surely need not

\footnotetext{
23 Id. at 26.

207 Id.

28 Id. at 28-29.

231 Id. at 29.

210 Id. at 27.
} 
be told how to complain" about his utility bill. ${ }^{241}$ The Justice's reliance on his perception of the capabilities of the ordinary citizen and the initiative such a citizen must be able to bring in enforcing his rights, as well as his assertion of the adequacy of common-law remedies, disregards the difficulties that may be faced by the poor or uneducated in opposing arbitrary or mistaken government action. ${ }^{242} \mathrm{~A}$ postdeprivation judicial remedy will not necessarily deter mistaken government action that might be prevented by a prior hearing, especially when that action results from bureaucratic carelessness. ${ }^{243}$

Memphis Light exemplifies Justice Stevens's more general reluctance to extend the procedural due process protections to government impact on ordinary life situations. Realizing that federal judicial remedies cannot be provided for every injustice in society, ${ }^{244}$ he has concluded that the courts should concentrate their resources on cases of greater magnitude. As he said in Bishop: "The federal court is not the appropriate forum in which to review the multitude of personnel decisions that are made daily by public agencies." ${ }^{245}$ In Memphis Light he remarked that judges have the ability to appraise "the fairness of legal remedies and judicial proceedings," but no comparable ability "to balance the cost of scheduling thousands of billing conferences against the benefit of providing additional protection." 246 Justice Stevens's approach is that of a realist: "We must accept the harsh fact that numerous individual mistakes are inevitable in the day-to-day administration of our affairs. The United States Constitution cannot feasibly be construed to require federal judicial review for every such error."'247

The Justice's willingness to tolerate the transgressions "inevitable" in the day-to-day operation of the government finds support in the view that when the government acts in a manner having an effect on a broad cross section of citizens, the nature of its political relationship to the populace will guarantee due process.

${ }^{211}$ Id. at 26. Indeed, Justice Stevens implied that even the telephone number and address of the utility printed on the termination notice, while "helpful" to the customer, would not be mandated by due process. Id.

212 See L. TRIBE, supra note 12, § 10-19, at 561. See generally Michelman, The Supreme Court and Litigation Access Fees: The Right to Protect One's Rights (pt. I), 1973 Duke L.J. $1153,1175$.

${ }^{213}$ Cf. L. TRIBE, supra note $12, \S 10-18$, at 557 (postdeprivation hearing "can never recreate the primary encounter with the decisionmaker that the individual might reasonably seek").

24436 U.S. at 25 n.7.

215426 U.S. at 349.

214436 U.S. at 30.

217 Bishop v. Wood, 426 U.S. 341, 349-50 (1976). 
The notion goes beyond the somewhat dubious argument that the threat of judicial remedies provides an adequate check on arbitrary government action. Where the government's role as provider of services or employer affects several strata of society, the more pervasive political deterrent on government behavior may justify a lower level of judicial involvement.

\section{Expansive Due Process Protection for Deprivations of Liberty}

Justice Stevens's sometimes narrow view of due process protections is also explicable in terms of the nature of the individual interest at stake. The Justice's dissent in Ingraham v. Wright, ${ }^{248}$ in which he argued that the eighth and fourteenth amendments protect school children from arbitrarily inflicted corporal punishment, ${ }^{249}$ acknowledged that certain types of government invasion of individual interests can be vindicated adequately by postdeprivation state remedies and thus require no predeprivation procedural safeguards. In cases involving defamation or invasions of property interests, the Justice emphasized, "a postdeprivation state remedy may be all the process that the Fourteenth Amendment requires." ${ }^{250}$ When such an invasion occurs, "there is a greater likelihood that a damages award will make a person completely whole than when an invasion of the individual's interest in freedom from bodily restraint and punishment has occurred." ${ }^{251}$ When an individual's liberty interest is implicated, however, Justice Stevens adopts a markedly different approach. In Ingraham he joined Justice White's dissent, which found a postdeprivation damage remedy to be inadequate

${ }^{243} 430$ U.S. 651,700 (1977) (Stevens, J., dissenting).

210 Id.

250 Id. at 701 (Stevens, J., dissenting).

${ }^{251}$ Id. Justice Stevens's greater solicitude for persons facing the loss of their liberty than for those facing a property loss does not imply, of course, that he always decides in favor of criminal defendants, or that he believes that due process protection is never required for the protection of property. See, e.g., Henderson v. Kibbe, 431 U.S. 145 (1977) (Stevens, J.) (rejecting the claim of a state prisoner, on habeas corpus, that his due process rights were denied by insufficient instructions to the jury); Shaffer v. Heitner, 433 U.S. 186, 217 (1977) (Stevens, J., concurring) (finding that Delaware sequestration statute, which permitted stock in Delaware corporations owned by persons without any contact with the state to be seized by the state in connection with civil lawsuits in Delaware, denied due process). See also Moore v. City of E. Cleveland, 431 U.S. 494 (1977), in which the Court struck down a zoning ordinance having the effect of allowing a grandmother to live with her grandsons if they are brothers, but not if they are cousins. The plurality, in an opinion written by Justice Powell, reasoned that the ordinance "deeply intrudes into family associational rights." Id. at 510 (plurality opinion). Justice Stevens, concurring, reasoned instead that the ordinance is not "a permissible restriction on appellant's right to use her own property as she sees fit." Id. at 513 (Stevens, J., concurring). As the case illustrates, it is sometimes difficult to characterize a particular right as involving "liberty" or "property." 
process for corporal punishment inflicted by school officials. ${ }^{252}$

When faced with an alleged invasion of liberty rather than property, Justice Stevens also applies a different approach to determing whether a deprivation of constitutional magnitude has occurred: the Justice is much more willing to find an invasion of a protected interest at the first stage of the protected-interest analysis when liberty is at issue. ${ }^{253}$ The Justice's more liberal approach to identifying a liberty interest reflects his distinctive view of its source. Although he is in agreement with the majority of the Court that property is based on entitlements created by "an independent source such as state law"254 outside the Constitution, Justice Stevens has sharply disputed the apparent conclusion of a six-Justice majority in Meachum v. Fano"255 that a "liberty interest may 'originate in the Constitution,' or it may have 'its roots in state law.' "25s Justice Stevens insisted that liberty is an endowment of the Creator, and not the product of the Bill of Rights or the laws of the state: "It is that basic freedom which the Due Process Clause protects, rather than the particular rights or privileges conferred by specific laws or regulations." ${ }^{257} \mathrm{He}$ argued that "at the very minimum" the liberty interest includes the "right to be treated with dignity."258

How this sweeping language may be applied in various contexts is not clear. ${ }^{259}$ In Meachum, a state prisoner challenged the procedures employed in his transfer from a medium to a maximumsecurity prison. In dissent, Justice Stevens advocated extending due process protection to prisoners whose status is altered to their

252430 U.S. at 683.

${ }^{2 s 3}$ Compare Meachum v. Fano, 427 U.S. 215 (1976) with Bishop v. Wood, 426 U.S. 341 (1976).

2st Bishop v. Wood, 426 U.S. 341, 344 n.7 (1976) (Stevens, J.) (quoting Board of Regents v. Roth, 408 U.S. 564,577 (1972)).

$2 s 6427$ U.S. 215 (1976). Justice White wrote the majority opinion.

ss Id. at 230 (Stevens, J., dissenting) (quoting id. at 226 (majority opinion)) (citations omitted).

2s7 Id. (Stevens, J., dissenting).

2ss Id. at 233. Justice Stevens argued that without that dignity, a prisoner would be little more than a slave.

2s Justice Stevens's theory that citizens have a liberty interest in being treated with dignity is somewhat circular. The due process clause guarantees that citizens' liberty may not be infringed arbitrarily. It is not particularly helpful to conclude that the right not to be treated arbitrarily is itself a right which may not be infringed arbitrarily. But see L. TRuBs, supra note $12, \S \S 10-7$ to -12 (suggesting that procedural due process has an intrinsic value to the individual apart from ensuring nonarbitrary deprivations of other rights); Van Alstyne, Cracks in 'The New Property': Adjudicative Due Process in the Administrative State, 62 Cornell L. REv. 445, 483 (1977) (arguing that there is a liberty interest in freedom from arbitrary adjudicative procedures); Rubin, Job Security and Due Process: Monitoring Administrative Discretion Through a Reasons Requirement, 44 U. CH. L. REv. 60 (1976). 
"grievous loss,"260 without regard for whether that loss falls within the traditional rubric of deprivation of liberty. ${ }^{261}$ In this important respect he departed from the protected-interest analytical scheme:262 he allowed the weight of the prisoner's interest to govern the determination whether the invasion infringed his liberty. The Justice thus appears willing to construe the concept of liberty broadly, at least where human "dignity" is manifestly involved.

Justice Stevens's particular solicitude for deprivations of the liberties of prisoners-a powerless group uniquely at the mercy of the state-may also be seen in his dissent in Moody v. Daggett. ${ }^{263}$ In Moody, a federal parolee, imprisoned for two homicides committed while on parole, petitioned the court on habeas corpus for dismissal of a parole-violator warrant-based on those same crimes-issued and lodged with the federal prison, but not served on him. The challenged procedures permitted the parole board to postpone a hearing on the warrant until after Moody had completed his sentence on the newly committed felonies. ${ }^{264}$

The majority ${ }^{265}$-distinguishing Morrisey $v$. Brewer ${ }^{266}$ - held that Moody had not been denied due process. They reasoned that his current imprisonment resulted from the felony convictions rather than the parole revocation warrants and thus that no liberty interest had been invaded. The Court emphasized that the parole board would have to hold a hearing before revoking parole, but that postponing the hearing until after expiration of the intervening sentence would improve evaluation of Moody's "ability . . . to live in

260 427 U.S. at 235.

at The majority held that the prisoner's interest in remaining in the same facility was "too ephemeral and insubstantial to trigger procedural due process protections." Id. at 228. Justice Stevens considered this too narrow a view of the prisoner's liberty interest. Id. at 229. 35. Cf. Montanye v. Haymes, 427 U.S. 236, 244 (1976) (Stevens, J., dissenting) (prisoner's transfer not necessarily so "grievous" a loss as to demand due process protection; he nevertheless had a right to trial on the question of whether his first amendment rights were infringed by the transfer).

212 See L. TrIBE, supra note $12, \S 10-12$, at 532-33. Traditional protected-interest analysis becomes attenuated in prisoners' rights cases. It is difficult to determine which rights belonging to persons in confinement should be classified as "liberty interests." Perhaps the only available course for the courts to take is to classify prisoners' rights according to weight rather than to nature.

213 429 U.S. 78, 89 (1976) (Stevens, J., joined by Brennan, J., dissenting).

2a The effect of delaying a decision on parole revocation was that Moody would not be released upon completion of the homicide sentences, but would instead be detained awaiting completion of a parole revocation hearing. Justices.

2ts The majority opinion was written by Chief Justice Burger, who was joined by six

2xt 408 U.S. 471 (1972) (parolee arrested because of parole violation entitled to prompt hearing to determine whether parole should be revoked). 
society without committing antisocial acts." 267

Justice Stevens focused his analysis on the timing of the parole revocation hearing. He argued that the only interest the board had in delaying a hearing was to allow consideration of the parolee's behavior in prison. He further argued that a revocation hearing is not a proper forum for assessing a prisoner's fitness for release from a current imprisonment. ${ }^{268}$ On the other side of the scale, Justice Stevens identified reasons an inmate might have for wanting a prompt hearing: delay may result in the loss of the "fair opportunity to present facts in mitigation and to challenge the government's assertions" guaranteed by the Constitution; ${ }^{269}$ the existence of the detainer may affect the conditions and extent of custody; the uncertainty of his status may have a negative psychological effect on the inmate and reduce incentives for rehabilitation. Given the lack of a legitimate state interest in delaying the hearing, Justice Stevens concluded that the prisoner's interests necessitated a prompt hearing.

Justice Stevens did not acknowledge that since the petitioner was caught and convicted of two homicides while on parole, an immediate parole hearing would inevitably have resulted in revocation. Moody's true interest in a prompt hearing was essentially unrelated to the opportunity to present facts in mitigation, or to the uncertainty of his status: he wanted to serve his sentence resulting from revoked parole simultaneously with his current sentences. ${ }^{270}$ Moreover, it is far from clear that the uncertainty resulting from the deferral of a decision to allow the sentences to run concurrently would not provide salutary behavioral incentive. Justice Stevens's

217429 U.S. at 80 (quoting Morrissey v. Brewer, 408 U.S. 471, 480 (1972)). The Court said that the prediction of the prisoner's future behavior would be "both most relevant and most accurate" if made after expiration of the intervening sentence. Id.

2ts Justice Stevens apparently believed the function of a parole revocation hearing was limited to ascertaining the facts of any alleged violation of parole conditions or of any mitigating circumstances, and to determining whether those circumstances would justify revocation. He believed that decisions regarding the wisdom of releasing a prisoner, which the majority considered a part of the revocation hearing function, to be relevant only to a release hearing. Id. at 95.

23s Id. The constitutional claim springs from the right to be heard at a meaningful time and in a meaningful manner. See Mathews v. Eldridge, 424 U.S. 319 (1976). See also Morrissey v. Brewer, 408 U.S. $471,487-88$ (1972). Loss of evidence and dilution of the force of mitigating circumstances arising from a delay between commission of the parole violation and the revocation hearing might make the hearing less meaningful. See Moody, 429 U.S. at 95 . However, no claim that evidence would actually be lost or had been lost was made in Moody. Id. at $88 \mathrm{n} .9$.

77429 U.S. at $80-81$. In a footnote, Justice Stevens disputed the majority's conclusion that a prompt revocation hearing would necessitate concurrent sentences, but called the issue of no constitutional significance. Id. at 91 n.4. 
rejection of the idea that the board should take prison behavior into account in a revocation hearing disregarded the responsibility of the board not only to judge whether a violation of parole has occurred, but also to determine the proper response to the violation.

The Justice's apparent balancing of interests may have disguised a more general distaste for parole board discretion. Justice Stevens may have been convinced that indeterminate sentences are unfair and debilitating, preferring instead that prisoners have fixed release dates. ${ }^{271}$ If so, then his objection was to the concept of parole in general, and Moody v. Daggett should be seen as his attempt to decrease the power of parole boards. In a broader sense, the Justice may have concluded that the uncertainty brought about by parole board discretion is intolerable for a free man and that the liberty interest in human dignity is infringed by such a system.

\section{Justice Stevens's Unique Approach to Procedural Due Process}

While the protected-interest analysis employed by the Burger Court is potentially expansive, ${ }^{272}$ concerns about federalizing tortlaw ${ }^{273}$ and avoiding undue interference with government procedural decisions have increasingly led the Court to adopt narrow interpretations of the doctrine. With some exceptions, ${ }^{274}$ the Court has, during Justice Stevens's tenure, contracted the range of protected interests, ${ }^{275}$ the type of impact constituting a deprivation of a protected interest, ${ }^{276}$ and the extent of the due process requirement when such a deprivation has occurred. ${ }^{277}$ With respect to identification of protected interests, the Court has looked to positive lawstate, federal, or constitutional-as the source of both property and liberty interests; with respect to the process required, the Court has placed greater weight on the administrative costs to government and greater reliance on the adequacy of postdeprivation remedies. These aspects of the Court's due process analysis have been criticized for their failure to "define and protect those substantive and procedural rights that may not receive their due respect in the political process." 278

Justice Stevens's procedural due process opinions, as a group,

27 Many penologists consider indeterminate sentences, whose length may not be determined for years, unjust and irrational. See, e.g., N. MorRIs, The FUTURE of IMPRISONMENT 49 (1974). Justice Stevens quoted extensively from prison authorities who oppose the challenged practice on penological policy grounds. 429 U.S. at $93-95 \mathrm{nn} .8$ \& 9.

272 See generally Mashaw, supra note 195.

${ }^{27 s}$ See Mathews v. Eldridge, 424 U.S. 319, 349 (1976).

${ }^{274}$ Memphis Light, Gas \& Water Div. v. Craft, 436 U.S. 1 (1978).

${ }^{275}$ Meachum v. Fano, 427 U.S. 215 (1976); Bishop v. Wood, 426 U.S. 341 (1976).

276 Moody v. Daggett, 429 U.S. 78 (1976).

277 Ingraham v. Wright, 430 U.S. 651 (1977).

${ }^{278}$ L. TRIBE, supra note $12, \S 10-14$. 
stand in sharp contrast to those of the Court. When compared with the results reached by the Court, the Justice's opinions initially give the appearance of ad hoc decisionmaking. He wrote the majority opinion in Bishop, holding that no protected interest had been invaded, yet he dissented from the Court's similar holding, based on seemingly identical grounds, in Meachum. On the question whether due process had been afforded, Justice Stevens reached conclusions opposite to those of the Court, finding that postdeprivation remedies satisfied the due process requirement in Memphis Light, but not in Ingraham.

The Justice's opinions can, however, be understood as reflecting a consistent approach to procedural due process. As a first approximation, Justice Stevens's distinction is between invasions of liberty, which are protected by the full power of the courts, and invasions of property interests, which may sometimes be vindicated merely by the individual's initiative or his exertion of common-law rights. Faced with the recognition of the federal courts' inability to protect the whole of society against injustice, Justice Stevens has sought to focus the Court's concern upon certain fundamental liberty interests. ${ }^{279}$ Where government action affects only particular individuals or implicates fundamental human concerns, the individual is likely to be particularly vulnerable: in such cases the government may essentially be unaccountable for erroneous decisions and unfair procedures. But where the government is involved in normal day-to-day administrative activities affecting large numbers of individuals, Justice Stevens apparently has concluded that the possibility of political or legal repercussions from inaccurate or arbitrary government decisionmaking may provide adequate incentives for the development of fair procedures and sensible entitlement rules, thus making judicial intervention unnecessary. ${ }^{280}$

271 Although the Court has long recognized that due process protects "fundamental principles of liberty and justice which lie at the base of all our civil and political institutions," Hurtado v. California, 110 U.S. 516, 535 (1884), Justice Stevens's view of "fundamental interests" differs from the evolving Burger Court analysis of "protected interests." The Court has increasingly required a basis in positive state law as the source of a protected liberty interest. E.g., Meachum v. Fano, 427 U.S. 215 (1976). Justice Stevens's view is not one of adherence to the early-1970s position that due process protection extends to those cases in which the government has created an expectation or dependence in the individual. See The Supreme Court, 1975 Term, supra note 3, at 95. Rather, the Justice's thinking is closer to the pre-1970s view that due process must be accorded whenever government action causes a "grievous" deprivation of liberty or implicates some "core" interest founded on statutory, constitutional, or common law concepts of fairness. See L. TrIBE, supra note 12, $\$ 10-8$, at 506-08 and cases cited in $i d$. at $508 \mathrm{nn} .11,13$.

2x0 This basis for decisionmaking must be contrasted with that employed by the majority in Meachum. In Meachum, the Court declined to involve the judiciary in decisions "that traditionally have been the business of prison administrators rather than of the federal 
Although Justice Stevens's opinions in Bishop, Codd, and Memphis Light may give the appearance of an insensitivity to the discharged public employee or the terminated utility customer, his lack of solicitude in these cases is the necessary concomitant to his concern for the defendant sentenced to death, the prisoner at the mercy of his parole board or prison authorities, and the school child faced with a beating. The "lesser" cases must give way so that the courts may devote their attention to those who most need it. Unfortunately, the categories of rights requiring full judicial protection are not easily defined. Justice Stevens's initial liberty/property distinction can serve only as a starting point. A decision such as Codd illustrates that interests ordinarily described as "liberty"-in that case the interest in reputation-may fall into the Justice's lessprotected category. Justice Stevens's chief failure in his due process opinions has been in not providing a clear rationale for why particular interests are of greater importance than others. The Justice's distinctions appear to reflect an emphasis on human dignity as the quality of liberty that demands the heightened protection of the courts. The formulation is not very helpful, however. The concept of dignity is too amorphous and subjective a basis for predictable decisionmaking. ${ }^{281}$ For his scheme to succeed as an effective, but also fair, means of limiting the reach of procedural due process, Justice Stevens should articulate a rationale more responsive to the varied contexts in which due process claims arise.

\section{Equal Protection}

\section{A. Justice Stevens and Two-Tier Analysis}

Beyond mandating even-handed treatment of citizens, the equal protection clause of the fourteenth amendment has little specific content. Neither the general language nor the ambiguous history of the provision can serve as a clear guide to interpreting its limits on governmental action. ${ }^{282}$ Indeed, the shape of modern equal protection doctrine did not emerge until the $1950 \mathrm{~s}$, ${ }^{283}$ when the

courts." 427 U.S. at 225. Justice Stevens's analysis allowed him to reach different conclusions in Meachum and Bishop, yet adhere to a consistent concept of due process. The majority's rationale in Meachum demands that both cases be decided the same way.

2\$t The abuse of human dignity hardly seems unique to deprivation of liberty. The humiliation associated with an unjustified dismissal from employment or a denial of an essential service such as electricity may also demean the dignity of the individual affected.

${ }_{2 \times 2}$ Brest, The Supreme Court, 1975 Term-Foreword: In Defense of the Antidiscrimination Principle, 90 HaRv. L. REv. 1, 5 (1976).

${ }^{2 \times 3}$ Although originally interpreted to apply only to racially discriminatory laws, see The Slaughterhouse Cases, 83 U.S. (16 Wall.) 36,81 (1873), the equal protection clause was later expanded to govern some economic and social legislation. See Skinner v. Oklahoma, 316 U.S. 
Court began employing the provision vigorously for the purpose of eradicating gross disparities in the treatment of persons on the basis of race and other criteria. In an attempt to accommodate the egalitarian demands of the fourteenth amendment with the nation's fundamental commitment to majority rule through elected representatives, the Court devised an analytical scheme that has become known as the "two-tier" approach. ${ }^{284}$

Under two-tier analysis, the court first determines the level of scrutiny to be applied, then considers the validity of the classification under that standard. If the statutory classification involves economic or social regulation, the court will defer to legislative judgment: classifications ${ }^{285}$ based on such judgments will be struck down as violative of equal protection only if there is no rational connection between the legislative means and a legitimate state purpose. ${ }^{286}$ When a classification involves discrimination against a "suspect class" 287 or impairs the exercise of a "fundamental right," 288 however, deference to legislative judgment is considered unwarranted. Instead the court will engage in "strict scrutiny":289 it will uphold the legislation only if it is narrowly tailored to serve a compelling state interest. The most serious defect in this analysis is that it

535 (1942). Although by its terms the clause applies only to states, the Court, in Bolling v. Sharpe, 347 U.S. 497, 499-500 (1954), applied equal protection limitations to the federal government through the due process clause of the fifth amendment. Equal protection now applies to all levels of government and most areas of legislative concern.

2x+ An excellent judicial summary of the two-tier method is Justice Stewart's concurrence in San Antonio Independent School Dist. v. Rodriguez, 411 U.S. 1, 59 (1973). See generally Developments in the Law-Equal Protection, supra note 48, at 1076-133.

20 The equal protection clause independently confers no substantive rights; rather, it serves to measure the validity of classifications created by legislatures. San Antonio Independent School Dist. v. Rodriguez, 411 U.S. 1, 59 (1973) (Stewart, J., concurring).

$2 \times 6$ In order to survive the rationality test, a statute need only be justifiable in terms of some legitimate purpose, however tenuous or hypothetical. Most statutes are able to satisfy this burden. See, e.g., City of New Orleans v. Dukes, 427 U.S. 297 (1976). See generally Note, Legislative Purpose, Rationality, and Equal Protection, 82 Yale L.J. 123 (1972).

${ }^{2 \times 7}$ The paradigmatic suspect classification is one based on race. See Korematsu v. United States, 323 U.S. 214, 216 (1944). Other arguably suspect classifications are those based on alienage, Graham v. Richardson, 403 U.S. 365, $371-72$ (1971); national origin, Oyama v. California, 332 U.S. 633, 644-46 (1948); illegitimacy, Weber v. Aetna Cas. \& Sur. Co., 406 U.S. 164, $172-76$ (1972); and indigency, Griffin v. Illinois, 351 U.S. 12, 16-18 (1956). See generally L. TRIBE, supra note $12, \S 16-13$.

${ }_{2 \times x}$ Fundamental interests may include, in some fashion, travel, Shapiro v. Thompson, 394 U.S. 618, 630-31 (1969); voting, Harper v. Virginia Bd. of Elections, 383 U.S. 663, 670 (1966); rights inhering in the parent-child relationship, Levy v. Louisiana, 391 U.S. 68, 71 (1968); and privacy, Griswold v. Connecticut, 381 U.S. 479, 483-86 (1965). See generally L. Tribe, supra note $12, \S \S 16-7,16-8,16-10$.

200 The Court has used varying terminology. See Korematsu v. United States, 323 U.S. 214, 216 (1944) ("the most rigid scrutiny"); Graham v. Richardson, 403 U.S. 365, 372 (1971) ("close judicial scrutiny"); Frontiero v. Richardson, 411 U.S. 677, 688 (1973) ("strict judicial scrutiny"). "Strict scrutiny" seems to be the most convenient label for the process. 
eliminates close analysis beyond the initial classification. Once the level of scrutiny is chosen, the Court's judgment is virtually certain. Professor Gunther has described this approach as entailing "scrutiny that was 'strict' in theory and fatal in fact," or "minimal scrutiny in theory and virtually none in fact." 290

Two-tier analysis has been strongly criticized on the Court, both as an inaccurate description of the Court's method ${ }^{201}$ and as an undesirable approach to equal protection adjudication. ${ }^{292}$ Although the Burger Court has not abandoned two-tier analysis, the Court has sometimes departed from the strict two-tier approach: in its short-lived doctrine of the unconstitutionality of conclusive presumptions ${ }^{293}$ and, more importantly, in its use of a "middle-tier" of scrutiny when important-but not fundamental-rights, or questionable-but not suspect-classes are involved. ${ }^{294}$ Furthermore, the Court, in San Antonio Independent School District v. Rodriguez, ${ }^{295}$ adopted a restrictive standard that seemed to make unlikely the future recognition of any new suspect classes or fundamental interests. ${ }^{298}$

${ }^{200}$ Gunther, The Supreme Court, 1971 Term-Foreword: In Search of Evolving Doctrine on a Changing Court: A Model for Newer Equal Protection, 86 HARv. L. REv. 1, 8 (1972).

201 San Antonio Independent School Dist. v. Rodriguez, 411 U.S. 1, 98-99 (1973) (Marshall, J., dissenting) (the Court "has applied a spectrum of standards in reviewing discrimination allegedly violative of the Equal Protection Clause").

202 See, e.g., Beal v. Doe, 432 U.S. 438, 457 (1977) (Marshall, J., dissenting) (the court should "repudiate its outdated and intellectually disingenuous 'two-tier' equal protection analysis"); Craig v. Boren, 429 U.S. 190, 210 n. (1976) (Powell, J., concurring) ("There are valid reasons for dissatisfaction with the 'two-tier' approach.").

${ }^{203}$ In Vlandis v. Kline, 412 U.S. 441 (1973), the Court held that permanent or conclusive classification violates due process when a classification is "not necessarily or universally true in fact," id. at 452 , and "the State has reasonable alternative means of making the crucial determination." Id. The doctrine was apparently abandoned in Weinberger v. Salfi, 422 U.S. 749, 767-77 (1975). See Note, Equal Protection: Modes of Analysis in the Burger Court, 53 DEN. L.J. 687, 710-11 \& nn.77-84 (1976).

294 See, e.g., Craig v. Boren, 429 U.S. 190 (1976) (gender-based discrimination); Frontiero v. Richardson, 411 U.S. 677 (1973) (gender-based discrimination); James v. Strange, 407 U.S. 128 (1972) (discrimination against indigents); Eisenstadt v. Baird, 405 U.S. 438 (1972) (discrimination against unmarried persons). Cf. City of Charlotte v. Local 660, Int'l Ass'n of Firefighters, 426 U.S. 283 (1976) (municipal rule barring union dues check-off upheld after examination of rationale); Kahn v. Shevin, 416 U.S. 351 (1974) (deferential stance taken toward gender-based discrimination).

In general, the Court's approach reflects the application of varying standards of review for different classifications, dependent upon the invidiousness of the classification. See Note, supra note 293, at 715-28. This development has been dubbed "newer" equal protection. Gunther, supra note 290.

${ }^{295} 411$ U.S. 1 (1973). The Court held that wealth is not a suspect classification, and that education is not a fundamental right.

206 The Court described the "traditional indicia of suspectness" as being "saddled with such disabilities, or subjected to such a history of purposeful unequal treatment, or relegated to such a position of political powerlessness as to command extraordinary protection from the 
Justice Stevens has been highly critical of two-tier analysis. The first indication of his dissatisfaction with the method may be seen in his dissenting opinion in Mathews $v$. Lucas. ${ }^{297}$ In Lucas, respondent, the illegitimate son of a Social Security beneficiary, challenged, on equal protection grounds, ${ }^{298}$ several statutory presumptions of dependency that operated to require illegitimate-but not legitimate-children to prove dependency to receive survivors' benefits. The majority upheld the classification scheme on the basis of "administrative convenience." ${ }^{289}$ Although acknowledging that the presumptions were an imprecise predictor of dependency, the Court ruled that the classification scheme was permissible so long as the imprecision "does not exceed the bounds of substantiality tolerated by the applicable level of scrutiny." 300

In his dissent, Justice Stevens appeared to agree that discrimination against illegitimates should not trigger strict scrutiny, at least in the sense in which that term has usually been employed, ${ }^{301}$ although he did note that illegitimate children have been a "traditionally disfavored class in our society." ${ }^{302}$ Because traditional disfavor indicates that the classification may be the result of "[h]abit, rather than analysis," he noted, the Court "should be

majoritarian political process." Id. at 28. Since adopting this test, the Court has not found a new classification suspect, although the opportunity has presented itself. See, e.g., Mathews v. Lucas, 427 U.S. 495, 504-05 (1976) (illegitimates a specially disfavored class, but no finding of suspectness); Massachusetts Bd. of Retirement v. Murgia, 427 U.S. 307, 312-14 (1976) (aged persons not a suspect class).

The Court limited the class of fundamental interests to rights "explicitly or implicitly guaranteed by the Constitution." 411 U.S. at 33-34. The dissent, in contrast, argued that fundamentality of interests is to be judged on the basis of the "intimate relationship between a particular personal interest and specific constitutional guarantees." Id. at 115. (Marshall, J., dissenting). Since Rodriguez, the Court has apparently adopted a less vigilant approach to at least one of the interests formerly viewed as fundamental. See Sosna v. Iowa, 419 U.S. 393, 404-09 (1975) (right to travel). See also Salyer Lake Co. v. Tulare Lake Basin Water Storage Dist., 410 U.S. 719, 726-30 (1973) (arguably applying less scrutiny in a case involving the right to vote).

m 427 U.S. 495, 516 (1976) (Stevens, J., joined by Brennan \& Marshall, JJ., dissenting).

20x Equal protection claims against action by the federal government arise under the due process clause of the fifth amendment. Schneider v. Rusk, 377 U.S. 163, 168 (1964); see Delaware Tribal Business Comm. v. Weeks, 430 U.S. 73 (1977). Although the Court has stated that equal protection analysis is the same under the fifth and fourteenth amendments, see Buckley v. Valeo, 424 U.S. 1, 93 (1976); Bolling v. Sharpe, 347 U.S. 497 (1954), "the two protections are not always coextensive." Hampton v. Mow Sun Wong, 426 U.S. 88, 100 (1976). Actions impermissible under the fourteenth amendment may be justified when taken by the federal government to serve "overriding national interests." Id.

2m 427 U.S. at 509.

500 Id.

sor "[This] result should not be accepted without . . . something more than a "possibly rational' basis." Id. at 519-20. The normal strict scrutiny requires more than a possibly rational basis. See generally Developments in the Law-Equal Protection, supra note 48, at 1087-133. 
especially vigilant in examining any classification which involves illegitimacy." 303 The Justice argued that although the status of illegitimates may not justify invoking "strict scrutiny," it does require a closer evaluation of the classification than that provided by the simple rational relationship test. Finding the relationship between the end and the means "tenuous," and the Court's proposed justifications "nebulous inference upon inference," he concluded that "a fair evaluation of the competing interests at stake" required striking down the statute. ${ }^{304}$

What was implicit in Justice Stevens's dissent in Lucas was made explicit in his concurrence in Craig $v$. Boren, ${ }^{305}$ in which he expressly abandoned two-tier analysis: "There is only one Equal Protection Clause. It requires every State to govern impartially. It does not direct the courts to apply one standard of review in some cases and a different standard in other cases." ${ }^{306}$ Justice Stevens also expressed skepticism about the accuracy of two-tier analysis as a description of Court practice. Rather than representing two distinct standards of review, he said, it "is a method the Court has employed to explain decisions that actually apply a single standard in a reasonably consistent fashion." ${ }^{307} \mathrm{He}$ did not, however, attempt to articulate that "single standard," but proposed instead to provide "a careful explanation of the reasons motivating" his decision, in the belief that such explanations in particular cases would contribute more toward identification of the standard than would an articulation "in all-encompassing terms." 308

\section{B. The Search for a Single Standard: Three "Explanations"}

Craig involved a challenge to an Oklahoma statute setting the

300 Id.

sos Id. at 521-23. In striking contrast to Lucas is Justice Stevens's opinion for a unanimous Court in Mathews v. Diaz, 426 U.S. 67 (1976), which upheld Medicare provisions excluding certain aliens from benefits. In spite of his usual solicitude for the rights of aliens, see, e.g., Foley v. Connelie, 437 U.S. 291, 311 (1978); Hampton v. Mow Sun Wong, 426 U.S. 88,102 (1976), Justice Stevens, with slim justification, upheld the provisions in Diaz. Perhaps this may be explained by his argument that the provisions in Diaz represented discrimination hetween classes of aliens rather than between aliens and citizens. 426 U.S. at 80 . But this argument merely sidesteps the fact that an eligibility requirement, which only some aliens could meet, was imposed on aliens and not on citizens. The only other principled explanation for Justice Stevens's decision is that the federal government has such extraordinarily broad powers over aliens that equal protection analysis is misplaced. See Rosberg, The Protection of Aliens from Discriminatory Treatment by the National Government, 1977 Sup. CT. REv. $275,282-93$.

${ }^{305} 429$ U.S. 190, 211 (1976) (Stevens, J., concurring).

$30 \mathrm{Id}$. at 211-12.

307 Id. at 212.

${ }_{30 \times} I d$. 
minimum age for purchase of 3.2 percent beer at eighteen for women and twenty-one for men. ${ }^{309}$ Justice Stevens stated the question presented by the case as "whether the traffic safety justification put forward by the State is sufficient to make [this] otherwise offensive classification acceptable." ${ }^{310}$ With respect to the offensiveness of the classification, Justice Stevens found it to be neither as "obnoxious" nor as "inoffensive" as the majority and dissent had viewed it. The Justice gave three reasons for finding the classification "objectionable": it was based on "an accident of birth," it reflected an "almost universally rejected" tradition of discrimination against males of that age, and it exhibited a "perverse" relationship to the physical characteristics of men and women. ${ }^{311}$

Against the offensiveness of the classification, Justice Stevens balanced the state's purported justification for the statute. He admitted that the classification was not totally irrational, referring to evidence that more men than women in the eighteen to twenty-one year old age bracket do in fact both drive and drink, ${ }^{312}$ but concluded that the justification was nonetheless inadequate. First, he found it difficult to believe that the legislature's actual purpose in enacting the law was to promote highway safety. Rather, he thought the statute reflected "nothing more than the perpetuation of a stereotyped attitude about the relative maturity of the members of the two sexes." 313 Second, assuming that traffic safety was the legislature's true motive, he doubted that the statute could have its intended effect. ${ }^{314}$ Finally, even "assuming some such slight benefit" from the classification, Justice Stevens viewed the benefit as insufficient justification for the "insult to all of the young men of the State" that the classification involved. ${ }^{315}$

Further light may be cast upon Justice Stevens's equal protec-

300 Justice Brennan's majority opinion, in which Justice Stevens also joined, struck down the statute. The Court applied a test stricter than the ordinary rational basis test: "[C]lassifications by gender must serve important governmental objectives and must be substantially related to achievement of those objectives." Id. at 197. The statute did not meet this test. Earlier cases had rejected "'archaic and overbroad' generalizations" on the basis of sex, id. at 198, and the factual basis for the classification-more teenage males than females drink and drive-had not been sufficiently established.

310429 U.S. at 213.

III Id. at 212-13.

32 Id. at 213.

313 Id. at 213 n.5.

31 Justice Stevens's conclusion was based on empirical data in the record. Id. at 213-14.

IIS Id. at 214. It is not immediately apparent why Justice Stevens concluded that an "insult" which affected no protected rights was of constitutional dimension. Cf. text and notes at notes 225-228 supra (inhospitable to claim of "stigma" absent proof of deleterious consequences). 
tion approach by comparing his opinions in Califano v. Jobst $t^{316}$ and Zablocki $v$. Redhail. ${ }^{317}$ Jobst involved a challenge to provisions of the Social Security Act that terminated child benefits upon the marriage of the child to a person not also eligible for benefits. As respondent's case showed-his wife was also disabled, but not eligible for benefits - these provisions could work great hardship upon a class of persons without apparent reason. Justice Stevens, writing for a unanimous Court, upheld the provisions after applying a rationality test. He found distinctions on the basis of marital status relevant to the determination of dependency. ${ }^{318}$ Moreover, he noted that the challenged provisions served to ameliorate the harshness of the former statute, which had terminated benefits upon any marriage. He declined to find the provisions invalid merely because they did not completely eliminate the possibility of a harsh result. ${ }^{319}$

In Zablocki, respondent challenged a Wisconsin statute that prohibited residents from marrying without court permission if they had minor children who were not in custody but were the subject of a court-ordered support obligation. Justice Stevens, concurring in the judgment, characterized the statute as determining who might enter marriage, thus distinguishing it from Jobst, which merely involved an economic impediment to marriage. "The economic aspects of a prospective marriage are unquestionably relevant to almost every individual's marriage decision. But I know of no other state that denies the individual marriage partners the right to assess the financial consequences of their decision independently." 320

While finding the individual's interest more compelling in Zablocki than in Jobst, he also found the governmental purpose in Zablocki unpersuasive. The purpose itself was legitimate: to promote counselling of the parents and protection of the out-of-custody child. But Justice Stevens found the effect of the statute "either futile or perverse" with respect to at least four major classes of persons adversely affected by the statute. ${ }^{321} \mathrm{He}$ was thus able to find the statute unconstitutional without joining the majority's conclusion that marriage is a fundamental right. ${ }^{322}$

\footnotetext{
${ }_{316} 434$ U.S. 47 (1977) (Stevens, J.).

11744 U.S. 374,403 (1978) (Stevens, J., concurring).

31x 434 U.S. at $53-54$.

319 Id. at $\mathbf{5 4 . 5 8}$

520434 U.S. at 404 n.4.

${ }^{321}$ Id. at 406 (childless couples; couples, if forbidden to marry, whose children would be illegitimate; couples whose economic status will be improved by marriage; and couples who are so poor that the marriage will have no impact on the welfare status of their children).

s2z Id. at 406 (Stevens, J., concurring); see id. at 383-87 (majority opinion).
} 


\section{A Standard for All Cases, or a Standard for Each?}

Justice Stevens's assertion in Craig that the two-tier characterization of equal protection decisionmaking is "a method the Court has employed to explain decisions that actually apply a single standard" ${ }^{23}$ is a plausible one. "Strict" and "minimum" scrutiny can be regarded not as two exclusive, discrete standards of review, but rather as extremes on a continuum of possible priorities between state and individual interests. At the very least, the Court seems to be moving in this direction. Justice Powell, in his concurrence in Craig, ${ }^{324}$ for example, while noting that he "would not welcome a further subdivision of equal protection analysis," 325 recognized the inadequacy of two-tier analysis to deal with the full range of equal protection cases. ${ }^{326}$ Similarly, Justice Marshall in Dandridge $v$. Williams $s^{327}$ advanced an equal protection analysis that may be termed "sliding scale," an approach that seems close, if not identical, to that employed by Justice Stevens. A middle-tier equal protection analysis, which applies an "intermediate" standard of review, can be identified in a number of the Burger Court's decisions, primarily in cases concerning classifications deemed not quite "suspect"-such as gender or alienage-based discrimination-or individual interests deemed not quite "fundamental"-such as marital rights. ${ }^{328}$ Professor Gunther, who recognized the trend of these cases before Justice Stevens joined the Court, ${ }^{329}$ has termed this evolving standard "equal protection bite without strict scrutiny." 330

Although Justice Stevens has purposely eschewed labelling his approach to equal protection, ${ }^{331}$ his opinions suggest that it is essentially one of interest balancing. ${ }^{332}$ On one side of the balance

322429 U.S. at 212.

Is Id. at 210 .

325 Id. at $210 \mathrm{n}^{*}$.

526 Justice Powell has been somewhat ambivalent about the proper approach in equal protection cases. In Weber v. Aetna Cas. \& Sur. Co., 406 U.S. 164 (1972), he noted that the equal protection inquiry is "inevitably a dual one: What legitimate state interest does the classification promote? What fundamental personal rights might the classification endanger?" Id. at 172-73. In San Antonio Independent School Dist. v. Rodriguez, 411 U.S. 1 (1973), however, he specifically endorsed two-tier analysis. Id. at 17 .

52397 U.S. 471, 520-22, 528-30 (1970) (Marshall, J., dissenting).

s2x See cases cited at note 294 supra; L. TRIBE, supra note $12, \S \S 16-30,16-31$.

S2o Gunther, supra note 290, at 18-37.

$210 \mathrm{Id}$. at 12.

271 See Craig v. Boren, 429 U.S. 190, 212 (1976) (Stevens, J., concurring).

22 An interest-balancing approach contrasts sharply with two-tier analysis, which, at least in theory, admits of little balancing. No balancing of state against individual interests occurs under the rational relationship test; to be valid, the classification need merely serve some legitimate state interest and not be wholly irrational. Under strict scrutiny, balancing 
lies the individual interest affected by the classification, ${ }^{333}$ on the other side is the state's interest in making the classification. The more important the interest of the class affected by the classification, the more substantial is the state interest required to justify it, and the greater the burden on the state to show that it actually serves that interest. That an interest may be constitutionally protected does not necessitate application of "a 'level of scrutiny" so strict that a holding of unconstitutionality is virtually foreordained."334 On the other hand, Justice Stevens has insisted that when such protected interests are implicated, the state must have more than "a rational expectation of occasional and random benefit."

Justice Stevens's balancing approach-essentially a sliding scale scrutiny that shifts with the relative weights of the individual and state interests implicated-shares many of the characteristics identified as comprising "intermediate" review. ${ }^{336}$ The Justice first makes an assessment of the relationship between the challenged classification and the class of affected individuals. This inquiry may focus either on the nature of the classification, as in Lucas and Craig, ${ }^{337}$ or on the impact on some interest of the members of the affected class, as in Jobst and Zablocki. ${ }^{338}$ In addition to obviously suspect classifications, the Justice is particularly sensitive to legislative distinctions that are drawn on the basis of "accidents of

is only implicit; the relevant inquiry is not into the relative weights of the interests at stake, but into the nature of the state interest-to see if it is compelling-and into the classification-to see if it is narrowly tailored to achieve that interest. Although application of twotier analysis inevitably involves some balancing-for example, the weight of the state interest may affect the closeness of the fit between ends and means required in a strict scrutiny casethe doctrinal framework necessarily limits its use.

This individual interest is not always that of the plaintiff who has been disadvantaged by the classification: "The broad legislative classification must be judged by reference to characteristics typical of the affected classes rather than by focusing on selected, atypical examples." Califano v. Jobst, 434 U.S. 47, 55 (1977).

zos Zablocki v. Redhail, 434 U.S. 374, 406 n.10 (1978) (Stevens, J., concurring).

xis $I d$.

336 See L. Tribe, supra note 12 , $\S 16-30,16-31$. Professor Tribe identifies five "techniques" characteristic of intermediate review: assessment of the importance of the governmental interest, requirement of a "close fit" between legislative ends and means, requirement of a current articulation of the classification's rationale, limitation of "afterthought" justifications, and adjustment of the challenged legislative scheme to permit rebuttal in individual cases. Id. $\$ 16-30$. Professor Tribe's description of the first of these techniques indicates that the Court's use of intermediate review may, at least in some cases, be indistinguishable from the balancing approach we have attributed to Justice Stevens. Id. at 1082-83.

${ }^{207}$ Lucas, 427 U.S. at 520 (Stevens, J., dissenting); Craig, 429 U.S. at 213 (Stevens, J., concurring).

33x Jobst, 434 U.S. at 53-54 (Stevens, J., concurring); Zablocki, 434 U.S. at 404 (Stevens, J., concurring). 
birth" or that result from "habitual" or "traditional" ways of thinking about a class of individuals. ${ }^{339}$

Once he has characterized the challenged classification, the Justice engages in a multifaceted examination of the state justification for the provision. The weight of the state interest served by the statute is an important, but by no means dispositive, factor in the Justice's analysis. Unlike the rational relationship requirement under minimum scrutiny, Justice Stevens's balance demands a stronger showing of rational need for a discriminatory classification. If the relationship between legislative end and means is "tenuous"310 or if the effect of the classification is "futile" or "perverse" with respect to its purported purpose ${ }^{341}$ then he will vote to strike down the statute. Moreover, the Justice is unwilling to accept otherwise legitimate justifications that he concludes did not actually form the basis of the legislative decision to create the offending classification. ${ }^{32}$ Justice Stevens's balancing approach is thus a complex process: only after he has satisfied himself with respect to actual legislative purpose will the Justice balance the state's justification against the interests of the individual.

Justice Stevens's approach responds to two grounds of criticism of the Court's rigid two-tier analysis. First, it fills the gap between the poles of strict and minimum scrutiny, a dichotomy too limited to account for the many variables inherent in all but the most straightforward equal protection cases. ${ }^{3.3}$ The Justice's adoption of a "single standard," however, does not necessarily represent a total repudiation of the standards of two-tier analysis: his use of balancing is consistent with a continuing sensitivity to those situations that lie at the opposite extremes of his scale-the two-tier paradigms. At these extremes, the difference between refusing to participate in explicit balancing and recognizing that balancing yields a preordained result is merely one of semantics. Second, Justice Stevens's analysis tempers the substantial deference to legislative judgments accorded by minimum scrutiny. The Court's requirement, under two-tier analysis, of only a minimal rational

390 See Zablocki, 434 U.S. at 405 n.8 (Stevens, J., concurring); Jobst, 434 U.S. at 53 (Stevens, J.); Craig, 429 U.S. at 213 n.5 (Stevens, J., concurring); Lucas, 427 U.S. at 520 (Stevens, J., dissenting). See also Foley v. Connelie, 435 U.S. 291, 307-12 (1978) (Stevens, J., dissenting).

3. Lucas, 427 U.S. at 513-23 (Stevens, J., dissenting).

sı Zablocki, 434 U.S. at 403-06 (Stevens, J., concurring); Craig, 429 U.S. at 212-13 (Stevens, J., concurring).

312 See Part VI infra.

sis In this respect, of course, Justice Stevens is not alone on the Court, as evidenced by the Court's recognition of a middle tier of equal protection cases. See notes 328 \& 336 supra. 
connection between means and ends in all cases except those involving suspect classes or fundamental rights fails to respond to the actual irrationality or deceit that may sometimes exist in the legislative process. Justice Stevens, by carefully examining the legitimacy of proposed legislative justifications for discriminatory classifications, has significantly contributed to refining the analysis of those cases falling within the middle tier-age, gender, and alienage classifications.

The same aspects of a sliding scale that make it appealing engender difficulties, however. If two-tier analysis tends to defer too much to legislative judgments, Justice Stevens's brand of balancing may err in the other direction. ${ }^{344}$ In his equal protection opinions to date, Justice Stevens has reached results different from two-tier analysis only in those cases involving "questionable" classifications, cases in which other members of the Court have also applied intermediate review. It is conceivable (though not inevitable) that a balancing approach, coupled with a more searching requirement of rationality, might open a broader involvement of the courts in reviewing arguably sensitive, or even economic legislative classifications.

A more significant objection to the Justice's equal protection analysis is that a sliding scale is not a single standard at all, but rather a technique by which courts formulate separate standards of review on a case-by-case basis. Such an approach to equal protection decisionmaking does not fulfill the Court's function to define for legislatures their responsibilities under the Constitution. The two-tier approach has the virtue of putting legislatures on notice that certain classifications will not pass constitutional muster; sliding-scale analysis increases drastically the degree of judicial subjectivity in equal protection adjudication and gives little guidance to legislatures regarding the bounds of permissible legislation. Although judicial value choices still inevitably play a role in any equal protection decision, Justice Stevens's formulation may give the courts too free a hand to limit the exercise of legislative judg-

34 Jutice Rehnquist's strongly worded dissent in Trimble v. Gordon, 430 U.S. 762 (1977) (involving intestacy provisions regarding illegitimate children), although directed at the intermediate scrutiny applied in Justice Powell's majority opinion, strikes at the heart of Justice Stevens's equal protection analysis. Justice Rehnquist characterized the Court's general application of the equal protection clause, other than in racial discrimination cases, as "an endless tinkering with legislative judgments, a series of conclusions unsupported by any central guiding principle." Id. at 777. He disparaged the majority's requirement of a close fit between legislative purpose and statutory means as "second-guessing of legislative judgment in an area where this Court has no special expertise whatever." Id. at 783-84. In Justice Rehnquist's view, there is no "constitutional mandate" for the Court to "instruct" legislatures in the proper techniques of rational decisionmaking. Id. at 784 . 
ment or to usurp the broad factfinding and policymaking functions of the legislatures. ${ }^{35}$

\section{Due Process of Lawmaking}

The judiciary has traditionally been concerned with the results of lawmaking, not with the lawmaking process itself. For example, in United States v. O'Brien ${ }^{346}$ the Court rejected an argument that a law prohibiting draft card destruction was unconstitutional because Congress, in passing the law, intended to stifle political dissent. The Court declared: "It is a familiar principle of constitutional law that this Court will not strike down an otherwise constitutional statute on the basis of an alleged illicit motive." ${ }^{347}$ In explaining this principle, Chief Justice Warren stressed the difficulty of ascertaining the actual legislative motive underlying a statute on the basis of the statements of a small number of legislators, ${ }^{348}$ and the futility of striking down laws that could be reenacted with a suitably laundered legislative history. ${ }^{349}$ Although O'Brien involved a challenge based on the alleged contamination of a statute by an improper motive, the Court's aversion to scrutiny of actual legislative purpose has also been prominent in determining the rationality of statutes under two-tier equal protection analysis. ${ }^{350}$ In cases neither impinging on fundamental rights nor employing suspect classifications, the

${ }^{315}$ In what was hailed as the most important equal protection case of the decade, the Court considered the question whether the University of California could constitutionally discriminate in favor of members of minority groups in its medical school admissions. Regents of Univ. of Calif. v. Bakke, 98 S.Ct. 2733 (1978). Justice Stevens wrote an opinion concurring in part, dissenting in part, joined by Chief Justice Burger and Justices Stewart and Rehnquist, that did not reach the constitutional issue. Justice Stevens found the University's affirmative action program violative of Title VI of the Civil Rights Act of 1964, 42 U.S.C. $\S 2000 \mathrm{~d}$ (1976). Because five justices reached the constitutional question, it may be considered odd that Justice Stevens did not express his view. This may be explained by his reluctance to reach constitutional issues unnecessarily-even in dissent-or by the possibility that he originally drafted the opinion for a majority.

มเ 391 U.S. 367 (1968) (Warren, C.J.).

${ }^{313}$ Id. at 383. See also Fletcher v. Peck, 10 U.S. (6 Cranch) 87 (1810) (Marshall, C.J.) (upholding validity of land grant from Georgia despite allegations that state legislature was corruptly influenced in passage of enabling act).

Jix Cf. Washington v. Davis, 426 U.S. 229, 253 (1976) (Stevens, J., concurring) ("A law conscripting clerics should not be invalidated because an atheist voted for it.").

3. 391 U.S. at 383-84. Commentators have noted the disutility of invalidating what may be good law passed for "bad" reasons, see, e.g., Ely, Legislative and Administrative Motivation in Constitutional Law, 79 YALE L.J. 1205, 1215-16 (1970), as well as the impropriety of such judicial inquiry into the motives of a coordinate branch of government, see, e.g., Brest, Palmer v. Thompson: An Approach to the Problem of Unconstitutional Legislative Motive, 1971 Sup. CT. Rev. 95, 129-30. But see Schlesinger v. Ballard, 419 U.S. 498, 520 n.11 (1975) (Brennan, J., dissenting) (reliance on a hypothesized legislative purpose "is not properly deference to a decision that the legislature could have made but did not.").

${ }^{350}$ See generally Part V supra. 
Court has been willing to accept virtually any post hoc justification offered to demonstrate the rationality of a law, without inquiring into the actual or principal reasons behind its enactment. ${ }^{351}$

The Court's deferential attitude, expressed in O'Brien and evidenced in minimum-scrutiny equal protection decisions, appears to be waning, at least in equal protection cases. This phenomenon may be traced in part to the Burger Court's growing dissatisfaction with two-tier analysis..$^{352}$ In some decisions striking down classifications not quite "suspect" or involving rights not quite "fundamental,",353 the Court has formulated a demand that "the challenged distinction rationally further some legitimate, articulated state purpose." Furthermore, in some cases the Court has examined the source of a challenged classification, requiring that the decision be made by a governmental body competent to the task of rational decisionmaking. Judicial concern with the identity of the decisionmaking body and the process by which it decides reflects a recognition of what has been termed the right to "due process of lawmaking." 355 The doctrine goes beyond the equal protection notion that legislation must serve some rational purpose: a statute containing a discriminatory classification or implicating liberty or 'property interests must be enacted by a rationally purposive legislative process. Although the Court has not fully developed or explained ${ }^{356}$ the doc-

35 See, e.g., McGowan v. Maryland, 366 U.S. 420, 426 (1961) ("A statutory discrimination will not be set aside if any state of fact reasonably may be conceived to justify it.") (emphasis added); Allied Stores v. Bowers, 358 U.S. 522, 530 (1959).

$\$ 32$ See text and notes at notes 291-296 supra.

s5s See, e.g., Weinberger v. Wiesenfeld, 420 U.S. 636, 648-53 (1975) (gender-based distinction); Eisenstadt v. Baird, 405 U.S. 438, 446-54 (1972) (marital-status distinction). See also Schlesinger v. Ballard, 419 U.S. 498, 511-21 (1975) (Brennan, J., dissenting). See generally L. TrIBE, supra note $12, \S 16-30$, at 1083-88.

${ }^{351}$ McGinnis v. Royster, 410 U.S. 263, 270 (1973) (emphasis added). The Court in Royster, however, appeared to equate "articulated" with "argued on appeal." See id. at 27071.

335 The origin of the term has been credited to Professor Linde, Linde, Due Process of Laumaking, 55 NEB. L. REv. 197 (1976), and adopted by Professor Tribe, L. TriBE, supra note $12, \S 17-3$, at 1144, Professor Sager, Sager, Insular Majorities Unabated: Warth v. Seldin and City of Eastlake v. Forest City Enterprises, Inc., 91 HARv. L. REv. 1373, 1411-18 (1978), and Justice Stevens, Delaware Tribal Business Comm. v. Weeks, 430 U.S. 73, 98 n.11 (1977) (Stevens, J., dissenting). Each of the four has ascribed a different meaning to the term. Professor Tribe appears to have used the term most expansively, including within the scope of the due process of lawmaking inquiry "who promulgated the provision, to what ends, and in what manner." L. TrIBE, supra note 12, §17-3, at 1144. Justice Stevens's view is somewhat more circumscribed.

156 Although several cases have at least in dicta indicated a need for inquiry into actual legislative purpose, see notes 353-354 supra, it is arguable that each could have been decided on rationality or other grounds. Nevertheless, the lack of true purpose seems to have been at least a contributing factor to the decisions. For an early attempt to clarify the Court's inchoate approach, see Gunther, supra note 290, at 25-37. 
trine, Justice Stevens has been instrumental in its recent emergence. Several opinions by the Justice-in particular, those involving equal protection analysis ${ }^{357}$-indicate that he recognizes legislativepurpose $^{358}$ analysis as a legitimate judicial function.

\section{A. The Requirement of Rational Decisionmaking}

1. Questionable Classifications: Searching for Legislative Purpose. The due process of lawmaking theme appears in Justice Stevens's majority opinion in Hampton $v$. Mow Sun Wong. ${ }^{359}$ Respondents, resident aliens, challenged the constitutionality of federal civil service regulations limiting most federal employment to United States citizens. Relying on cases holding that states may not lawfully exclude resident aliens from the practice of law ${ }^{360}$ or from state employment $^{361}$ unless such exclusion is based on some legitimate state interest, respondents asked that the same equal protection standard be applied against the federal government. Mathews $v$. $D i a z,{ }^{362}$ decided on the same day as Mow Sun Wong, appeared to foreclose this argument. In Diaz, a unanimous Court, in an opinion written by Justice Stevens, refused to apply a strict standard of scrutiny to federal residency requirements for alien Medicare recipients. The decision was based on the ground that "it is the business of the political branches of the Federal Government . . . to regulate the conditions of entry and residence of aliens." ${ }^{363}$ Nevertheless, in Mow Sun Wong the Justice found that the employment restriction violated the due process clause of the fifth amendment.

The type of scrutiny Justice Stevens employed was unusual. Although he described aliens as an "identifiable class of persons

${ }^{557}$ This aspect of Justice Stevens's equal protection analysis was evident even before he joined the Court. See Special Project, The One Hundred and First Justice: An Analysis of the Opinions of Justice John Paul Stevens, Sitting as Judge on the Seventh Circuit Court of Appeals, 29 VAND. L. REv. 125, 136 (1976) ("his position in future decisions is likely to emphasize a rigorous questioning of legislative purpose" (discussing Cousins v. City Council, 466 F.2d 830, 857-61 (7th Cir.) (Stevens, J., dissenting), cert. denied, 409 U.S. 893 (1972)).

${ }^{2 s s}$ To some extent, "purpose" and "motive" are terms of art; "purpose" is most often used in equal protection cases to designate the legitimating governmental objective of a challenged classification. See, e.g., Trimble v. Gordon, 430 U.S. 762, 768 (1977). Thus a purported purpose may be distinguished from the "actual" or "motivating" legislative purpose. See id. The concept of "motive" is generally used in O'Brien-like cases, in which the inquiry is into actual legislative purpose. Justice Stevens generally uses the term "purpose" to mean "actual purpose." For a criticism of the failure to distinguish between purpose and motive, see id. at 782 (Rehnquist, J., dissenting).

33426 U.S. 88 (1976) (Stevens, J.).

34. In re Griffiths, 413 U.S. 634 (1973).

si Sugarman v. Dougall, 413 U.S. 634 (1973).

32426 U.S. 67 (1976) (Stevens, J.).

ss Id. at 84 . 
who ... . are already subject to disadvantages not shared by the remainder of the community," 364 the Justice purported to avoid the equal protection issue of whether the government interest was sufficiently compelling and the provision sufficiently related to that interest. ${ }^{365}$ Instead, Justice Stevens focused on the "procedural aspect" 366 of the case: he described the exclusion of aliens from government employment as a "deprivation of an interest in liberty." 367 Significantly, however, he did not assert that "some type of hearing" was required; as the dissent pointed out, the case involved no governmental action that required a hearing. ${ }^{368}$ Rather, the procedures in question were those employed in promulgating the regulation itself.

The Civil Service Commission had adopted the challenged regulation with the clear acquiescence, but not at the specific direction, of Congress and the President. ${ }^{369}$ Before the Court, the Commission proposed three justifications for the regulation: (1) it served as a bargaining chip for the President's negotiation of treaties; (2) it acted as an incentive for aliens to become naturalized citizens; and (3) it avoided the administrative inconvenience of identifying those jobs too sensitive to be filled by aliens. ${ }^{370}$ Justice Stevens rejected the first two justifications because they exceeded the narrowly circumscribed authority of the Civil Service Commission to make policy decisions concerning foreign affairs. ${ }^{371} \mathrm{He}$ rejected the third proposed justification, although it was arguably rational, because there was no evidence in the record that "the Commission actually made any considered evaluation of the relative desirability of a simple exclusionary rule on the one hand, or the value to the service of enlarging the pool of eligible employees on the other." ${ }^{372}$ When the federal government enacts a discriminatory rule that would violate

36 Id. at 102.

3s Mathews v. Diaz, 426 U.S. 67 (1976) would appear to have answered the question. Diaz's holding that the broad powers of Congress over immigration precluded strict judicial scrutiny of congressional classifications of aliens would seem to apply in Mow Sun Wong as well. Oddly, the issue carefully left open in Mow Sun Wong, see 426 U.S. at 117 (Brennan and Marshall, JJ., concurring), was apparently decided by a unanimous Court the same day in Diaz. See Rosberg, supra note 304, at 282.

ses 426 U.S. at 103.

37 Id. This determination is questionable. The Court has never expressly held that the right to federal employment, without more, is a liberty interest protected by the due process clause. See Cafeteria Workers Local 473 v. McElroy, 367 U.S. 886, $896-99$ (1961).

ses 426 U.S. at 121 (Rehnquist, J., dissenting).

s' See id. at 105-14 (Stevens, J.) (historical discussion of the role of Congress and the President in the exclusion of aliens from the federal civil service).

so Id. at 103-04.

sil Id. at 114-15. See text and notes at notes $408-414$ infra.

372 Id. at 115. 
equal protection if adopted by a state, the government must prove that the rule was actually intended to serve an "overriding national purpose." 373

The Justice's concern in Mow Sun Wong with "actual," rather than hypothetical, legislative purpose appeared again in his concurrence in Califano v. Goldfarb. ${ }^{374}$ In Goldfarb a four-Justice plurality, ${ }^{375}$ joined in the judgment by Justice Stevens, held unconstitutional a section of the Social Security Act providing that survivors' benefits be automatically paid to widows, but paid to a widower only upon proof that he had depended on his wife. The plurality found that the statute discriminated against the female wage earner, whose surviving spouse was deprived of benefits, and that the discriminatory classification violated the equal protection component of the fifth amendment's due process clause. ${ }^{376}$ The Court reached this result on the basis of an "inquiry into the actual purposes' of the discrimination." 377 The plurality concluded that "the differential treatment of nondependent widows and widowers results not . . . from a deliberate congressional intention to remedy the arguably greater needs of the former, but rather from an intention to aid the dependent spouses of deceased wage earners, coupled with a presumption that wives are usually dependent."'378 The plurality found this presumption insufficient to justify the discriminatory effects of the provision.

Justice Stevens, concurring only in the judgment, focused his attention upon the treatment of the recipients of benefits, rather than the wage earners, and decided that a classification treating women more favorably than men is not necessarily invidious. ${ }^{379}$ Moreover, he accepted as not "wholly irrational" 380 two hypothetical justifications for the classification: administrative convenience and "cushioning the financial impact of spousal loss" upon women. ${ }^{381}$ Like the plurality, the Justice examined the "actual reason" for the discriminatory statutory scheme. Since the statute authorized payment of $\$ 750$ million per year to widows who were not actually dependent on their spouses-hence, not within the broad purpose

I3s Id. at 103 (Stevens, J.).

37430 U.S. 199 (1977).

sis Justice Brennan wrote the plurality opinion, joined by Justices White, Marshall, and Powell.

s78 See note 298 supra. The plurality relied primarily on Weinberger v. Weisenfeld, 420

U.S. 636 (1975).

37730 U.S. at $212-13$.

378 Id. at 216-17.

57 Id. at 217 (Stevens, J., concurring).

ses Id. at 219.

sst Id. (quoting Kahn v. Shevin, 416 U.S. 351, 355 (1974)). 
of the statute-he concluded that Congress could not rationally have intended to discriminate in favor of widows for purposes of administrative convenience. ${ }^{382}$ With respect to the suggestion that Congress intended the discrimination to "compensate [women] for past wrongs," 383 Justice Stevens found no indication that the challenged provisions were the product of any such conscious purpose. ${ }^{384}$ Since the benefits of the provision accrued largely to women least likely to be victims of past discrimination, he concluded that "[r]espect for the legislative process precludes the assumption that the statutory discrimination is the product of such irrational lawmaking." 385

Justice Stevens's reasoning drew upon his opinion in Mow Sun Wong. When a statute employs a "questionable" classification-such as the gender-based distinction at issue in Goldfarb-" "due process requires that there be a legitimate basis for presuming that the rule was actually intended to serve [the] interest' put forward by the government as its justification." ${ }^{386}$ When Justice Stevens measured the challenged provision against this test, he found it constitutionally impermissible. ${ }^{387} \mathrm{He}$ concluded that Congress had never adverted to the question whether to distinguish surviving spouses on the basis of sex. ${ }^{388}$ Instead, the Justice declared, "habit, rather than analysis or actual reflection," led Congress to adopt the scheme: "[T] his discrimination is merely the accidental byproduct of a traditional way of thinking about females." 389

Justice Stevens has engaged in this form of analysis, though in

302 The rejection of the administrative convenience justification can be explained on two grounds: (1) it is irrational to spend such a large amount for benefits when it can be assumed the cost of making individual determinations would be much smaller or (2) the amount spent is so large that it can be assumed Congress never considered the administrative convenience rationale, or else it would have engaged in a cost-comparison analysis, no indications of which appeared in the legislative history. The former is standard equal protection analysis; the latter is consistent with the due process of lawmaking doctrine. The Justice's Goldfarb opinion, although not unequivocal, suggests the latter. 430 U.S. at 220.

$3 s$ Id. at 222 . See Kahn v. Shevin, 416 U.S. 351 (1974).

ss If any doubts existed about the true basis of this portion of the Goldfarb opinion, they were dispelled in Califano v. Webster, 430 U.S. 313 (1977), where Justice Stevens joined a per curiam opinion upholding Social Security provisions granting larger old age benefits to women than men. The legislative history made clear that the scheme was designed to compensate women for past discrimination.

sas 430 U.S. at 221 .

ste 430 U.S. at 223 (quoting Hampton v. Mow Sun Wong, 426 U.S. 88, 103 (1976)).

ss Justice Stevens declined to say that the same statutory scheme would be unconstitutional if reenacted pursuant to a "considered legislative choice." 430 U.S. at 223 n.9.

sss Id. at 222 .

sss Id. at 222-23. 
less detail, in other equal protection cases. In Craig $v$. Boren, ${ }^{380}$ the Justice examined the proferred justification of a statute discriminating against young men-promotion of traffic safety-and found the marginal benefits of the statute insufficient to outweigh the "insult" it imposed on 18-to-20-year-old males. ${ }^{391}$ An integral step in reaching this result was the Justice's conclusion that the legislature had not intended the statute to serve the ends of traffic safety. ${ }^{302}$ The lack of evidence of a valid legislative purpose led him to suspect the proposed rationale: "There is, of course, no way of knowing what actually motivated this discrimination, but I would not be surprised if it represented nothing more than the perpetuation of a stereotyped attitude about the relative maturity of the members of the two sexes in this age bracket." "T33 The significance of this analysis is not that the Justice found a "traditional way of thinking" to be an impermissible basis for a discriminatory classification, but rather that he was willing to scrutinize the legislative process to determine what had actually motivated the legislature. ${ }^{394}$

2. The Requirement of an Articulated Purpose. In Mow Sun Wong, Goldfarb, and Craig, Justice Stevens voted to strike down a statute, admittedly rational in terms of a proposed justification, in part because he believed that the true motivation for the provision was impermissible. Moreover, in each case the challenged classification-based on gender in two of the cases and alienage in the third-was "sufficiently questionable" 395 that equal protection doc-

30 429 U.S. 190 (1976) (Stevens, J., concurring). See text and notes at notes 309-315 supra.

${ }^{31} 429$ U.S. at 213-14.

312 Id. at 213 . The lack of any legislative history on the point and the contrary conclusion suggested by related statutory provisions convinced the Justice on this issue.

${ }^{303} \mathrm{Id}$. at n.5.

34 An equal protection opinion focusing on a "traditional way of thinking," but less clearly utilizing due process of lawmaking analysis, is Justice Stevens's dissent in Mathews v. Lucas, 427 U.S. 495 (1976), see text and notes at notes 297-304 supra. Justice Stevens concluded the presumption that illegitimate children were not dependent was so tenuous that a statutory exclusion of such children from survivors' benefits "must either be irrational, or serve a purpose other than the one by which it is essentially justified." 427 U.S. at 522 n.4. While the irrationality of the classification would probably be sufficient for the Justice to strike down the statute on equal protection grounds, Congress's failure to consider the possibility of dependency of illegitimates-"the product of a traditional way of thinking of illegitimates as less deserving," $i d$. at 523-clearly underlay his objection to the provision. See also Foley v. Connelie, 435 U.S. 291, 307 (1978) (Stevens, J., dissenting) (search for actual purpose revealed all justifications adverted to by Congress either irrational or impermissible).

sus Califano v. Goldfarb, 430 U.S. 199, 223 (1977) (Stevens, J., concurring) (quoting Hampton v. Mow Sun Wong, 426 U.S. 88, 103 (1976) (Stevens, J.)). Justice Stevens, however, did not explain how a classification became "sufficiently questionable."

Gender has attracted considerable judicial support for inclusion in the list of "suspect classifications," see Frontiero v. Richardson, 411 U.S. 677 (1973) (Brennan, J., for a fourJustice plurality), but a majority of the Court has never so labelled it. 
trine required evidence of legislative intent to serve a legitimate purpose. Justice Stevens appears, however, to have extended his motive analysis beyond scrutiny of questionable classifications.

In Delaware Tribal Business Committee v. Weeks, ${ }^{396}$ appellee challenged a statute excluding one subgroup of Delaware Indians from a cash distribution made in compensation for breach of an 1854 treaty. The reason for the exclusion was neither impermissible nor outmoded; the legislative history indicated that the subgroup was excluded through mere congressional inadvertence. The majority determined the proper equal protection standard of review in light of the broad congressional authority in Indian matters: ${ }^{397}$ a classification is valid " [a]s long as the special treatment can be tied rationally to the fulfillment of Congress's unique obligation toward the Indians." "The majority found, on the basis of three tenuous hypothetical justifications, ${ }^{398}$ that Congress's exclusion of appellees could rationally be tied to its "unique obligation" and upheld the statute.

Justice Stevens cast the lone dissenting vote. He disagreed with the majority's conclusion that the justifications offered were rationally tied to Congress's obligation to Indians. In his view, four factors demanded that the statute be struck down: the "more than . . . ordinary" interest the claimants had in equal treatment, ${ }^{399}$ the absence of any practical need for discrimination among the Delawares, the absence of a "principled justification" 400 for the discrimination, and the lack of evidence that the discrimination was a deliberate choice of Congress. ${ }^{401}$ The first three factors cited by the Justice reflect his dispute with the majority on the equal protection issue. The fourth, however, goes beyond the traditional bounds of equal

330 U.S. 73 (1977).

sn The congressional authority over the management and distribution of lands and property of the tribes is derived "both explicitly and implicitly from the Constitution." Id. at 85 (quoting Morton v. Mancari, 417 U.S. 535, 551-52 (1974)).

s3 The proposed justifications were that the excluded subgroup was not a recognized tribal entity, that it had been excluded from an earlier distribution, and that it was included in statutory language designed to exclude a related group for good reason. See $\mathbf{4 3 0}$ U.S. at 85-89. Justice Blackmun strongly criticized each of the justifications, but joined in the decision nevertheless. Id. at 90 (Blackmun, J., concurring).

3' Id. at 97 (Stevens, J., dissenting). Justice Stevens noted that Congress has a "special responsibility to deal fairly with similarly situated Indians." Id. at 97 n.8.

100 Id. at 97 . See note 398 supra.

401 The only hint that the excluded Indians merited special constitutional protection was Justice Stevens's enigmatic statement that "members of the class whose rights were adjudicated by the Indian Claims Commission have more than an ordinary interest in equal treatment." 430 U.S. at 97. This extraordinary interest, which Justice Stevens did not explain, seems more a product of congressional responsibility than the characteristics of the group. See notes 397 \& 399 supra. 
protection analysis. Unlike Goldfarb and Mow Sun Wong, Delaware Tribal did not involve an invidious classification. ${ }^{402}$ Nevertheless, the purposelessness of the distinction moved Justice Stevens to scrutinize the proposed justifications for the legislation more carefully than did the other members of the Court. Although he expressed his reluctance to "suggest that the constitutionality of legislation should turn on the actual motivation, or lack thereof, of the legislators who participated in the legislative process," 403 the Justice examined that process and found the lack of any legislative purpose dispositive. Because he could detect no evidence of "actual legislative choice," he concluded that there had been "a deprivation of property without . . . 'due process of lawmaking." "404

Justice Stevens's concentration on process at the legislative level, which separated him sharply from the rest of the Court in Delaware Tribal, reveals the unique nature of the due process of lawmaking inquiry. The majority's equal protection analysis, which focused on the possibility of invidious discrimination, ignored what was crucial to Justice Stevens's analysis: the flawed decisionmaking process itself violated the Constitution. The Justice's insistence, in Delaware Tribal, on an articulated congressional purpose and his refusal to accept hypothetical justifications-like his search for actual governmental motive in Mow Sun Wong and Goldfarb-is essentially an equal protection approach. But some of the language in his opinions is that of procedural due process: he first identifies the liberty or property interest at stake, then determines the procedures required of the government before an individual may be deprived of that interest. ${ }^{405}$ Thus, to answer the substantive question - whether a classification is adequately supported by government

102430 U.S. at 97 . The legislative history plainly showed that Congress was unaware that a separate subgroup of the Delawares with identical claims existed. See id. at 89 (majority opinion).

103 Id. at 97 (Stevens, J., dissenting).

in Id. at 98. Justice Stevens borrowed the phrase "due process of lawmaking" from Linde, supra note 355 , but did not follow the reasoning of the article. 430 U.S. at 98 n.11.

Justice Stevens's dissent in Delaware Tribal can be explained as a finding of irrationality, 430 U.S. at 94 ("the lack of any rational explanation for the legislative malfunction"); Justice Blackmun's concurrence made it clear that even under traditional minimum scrutiny the statute was not easy to uphold. See note 398 supra. The importance of the case, however, is not that Justice Stevens dissented, but in the reasons he assigned for his dissent. He expressly stated he was "not prepared to say that if Congress had actually reviewed the status of the Kansas Delawares, it might not have found some principled basis for treating them differently from other Delawares." Id. at 97.

its That the concept of procedural due process is usually concerned with individualized determinations and not with promulgation of general rules was apparently no barrier to its special use in these cases. 
interests-the Court must first study the legislative process to determine which government interests were in fact part of the legislative purpose.

\section{B. The Proper Decisionmaker}

The requirement that a discriminatory statute or regulation result from a conscious and articulated judgment that such a classification serves a legitimate governmental purpose, although accounting for Justice Stevens's scrutiny of the legislative processes in Goldfarb, Craig, and Delaware Tribal, only partially explains the Justice's opinion in Mow Sun Wong. Justice Stevens rejected two of the three rationales proposed by the Civil Service Commission $^{408}$-facilitating treaty negotiations and providing an incentive for aliens to become citizens-not because the Commission was not motivated by such concerns, but because it could not have been. Justice Stevens's requirement that there be a "legitimate basis" for presuming that a governmental enactment was intended to serve a valid purpose thus takes on a more expansive meaning. Due process, he concluded, demands not only that the exclusion of aliens from the civil service further a valid purpose intended by the enacting body, but that such a regulation be enacted by a body "having direct responsibility for fostering or protecting" the governmental interests supposedly served by that policy. ${ }^{407}$ Both the interest served by the classification and the reasons for choosing to serve that interest through the means chosen must be considered by a responsible governmental entity.

Justice Stevens was willing to "assume" that had the citizenship requirement been "expressly imposed" by the President or Congress, the proffered "national interest" justifications might have sufficed..$^{408}$ But, he concluded, neither Congress nor the President had ever specifically required the Commission to establish citizenship as a condition of civil service employment. ${ }^{409}$ Rather, the Commission had acted independently pursuant to its delegated authority. Although the President, acting under his power delegated by

406 U.S. at 114-15.

4n Id. See Rosberg, supra note 304, at 279 . The regulation struck down was promptly reissued by the President as an Executive Order, without any statement of reasons, Exec. Order No. 11,935, 3 C.F.R. 146 (1976), reprinted in 5 U.S.C. app. $\$ 3301$ (1976), and has been upheld by the Seventh Circuit on the basis of Mow Sun Wong. Vergara v. Hampton, 581 F.2d 1281 (7th Cir. 1978).

426 U.S. at $103,105$.

40 Id. at 105. Justice Stevens conceded that when the Commission was established, Congress might well have assumed that a citizenship requirement would be applied, but he concluded that such an assumption "is by no means equivalent to a considered judgment that it should do so." Id. at 107. 
Congress ${ }^{410}$ had authorized the Commission "to establish standards with respect to citizenship . . . which applicants must meet" to qualify for civil service employment, ${ }^{411}$ Justice Stevens concluded from the language of the Civil Service Act ${ }^{412}$ that promotion of the efficiency of the Service was the only basis upon which the Commission could justify its regulations denying aliens access to civil service jobs. ${ }^{413}$ With regard to the broader policy justifications, the Justice refused to "presume that the Chairman of the Civil Service Commission . . . was deliberately fostering an interest so far removed from his normal responsibilities."'14

Justice Stevens's conclusion that the Commission's decisionmaking process was beyond the scope of its responsibility is perplexing. As Justice Rehnquist noted in his dissent-and which Justice Stevens presumably would not dispute-“Congress, through the President, obviously gave responsibility [for determining citizenship requirements] to the Civil Service Commission." 115 Justice Stevens, however, apparently relied on a unique variant of the nondelegation doctrine. Where constitutionally protected interests are affected by the exercise of a delegated power, such a decision must be made by a governmental body responsible for the policies underlying the decision. Thus, although Congress may delegate certain functions, its constitutionally mandated policymaking role in certain areas-such as foreign policy-may not be delegated..$^{416}$ Such

119 5 U.S.C. $\$ 3301$ (1976) provides that the President shall have the power to "prescribe such regulations for the admission of individuals into the civil service in the executive branch as will best promote the efficiency of that service."

111 Exec. Order No. 10,577, 3 C.F.R. 218 (1954).

"See note 410 supra.

113426 U.S. at 113, 114.

III Id. at 105. The requirement that an administrative agency confine its attention to matters properly within its jurisdiction is not new. See, e.g., FCC v. RCA Communications, Inc., 346 U.S. 86 (1953). These cases, however, involve "adjudication," not "legislation"; they concerned determinations of an individual party's rights rather than promulgation of a general rule. This is arguably an important distinction. See text and notes at notes $428-430$ infra.

415426 U.S. at 125 (Rehnquist, J., dissenting).

II Apparently, however, Justice Stevens does not mean that all agencies are incapable of implementing "overriding national interests." "If the agency which promulgates the rule has direct responsibility for fostering or protecting that [overriding national] interest, it may reasonably be presumed that the asserted interest was the actual predicate for the rule." Id. at 103. The question, of course, is how one identifies those national interests that may be delegated and those agencies or other government bodies to which they may be so delegated. With respect to the decision to exclude aliens from the civil service, Justice Stevens said:

Since those residents were admitted as a result of decisions made by the Congress and the President, implemented by the Immigration and Naturalization Service acting under the Attorney General of the United States, due process requires that the decision to impose that deprivation of an important liberty be made . . . at a comparable level of government. 
an approach appears strikingly at odds with the accepted concept of delegation. ${ }^{417}$ To say that Congress may broadly delegate its powers, but that its delegatees may exercise those powers only on the basis of narrowly circumscribed reasons would seem to render the authority of such bodies nugatory when they attempt to promulgate regulations having a differential impact on various groups.

This aspect of Mow Sun Wong, it would seem, can only be understood as an attempt by Justice Stevens to ensure that deprivation of protected individual interests in the name of "overriding national interest" be the result of a decisionmaking process that is "reflective" 118 and is made by a body accountable to the people. 419 When Congress delegates authority to an agency, the decisionmaking process becomes significantly further removed from one source of government accountability: the voters. When that agency purports to act on the basis of some essential national policy interest, as opposed to administrative efficiency, the "political" nature of its decisions removes it from the reach of the other source of accountability: judicial review.

City of Eastlake v. Forest City Enterprises, Inc. ${ }^{420}$ involved another variation on the problem of permissible delegation of legislative power. The Court upheld an Eastlake, Ohio, provision that

Id. at 116 (emphasis added) (footnote omitted). What is such a "comparable level of government"? Presumably it would not be the Immigration Service, but what of the Attorney General? Professor Sager's suggestion that such a decision must be made by "a governmental entity which is so structured and so charged as to make possible a reflective determination that the action contemplated is fair," Sager, supra note 355, at 1414, is not particularly helpful. One important distinguishing factor might be the degree of direct oversight of the agency by either Congress or the President. This would be consistent with the Justice's apparent concern with the accountability of governmental rulemaking bodies. See text at note 432 infra. Justice Stevens noted in Mow Sun Wong that under the statute the Commission was free to "retain or modify its citizenship requirement without further authorization from Congress or the President." 426 U.S. at 113 (footnote omitted).

11 Justice Rehnquist's dissent asserted that the majority's approach to delegation would "dismantle the entire structure of the Executive Branch." 426 U.S. at 124 (Rehnquist, J., dissenting). He argued that the "decision to exclude aliens from the civil service is a political decision reserved to Congress." Id. If Congress has properly delegated this decision to an agency, according to Justice Rehnquist, the courts may no more review the reasons for the agency's decision than the reasons underlying a decision made directly by Congress. Id. In other words, once Congress delegates the authority to make a decision, it delegates the responsibility to consider all those factors that Congress might take into account in making such a decision.

118 Sager, supra note 355 , at 1414.

41. See Rosberg, supra note 304, at 280:

On this sensitive matter Congress and the President would not be permitted to hide behind the Civil Service Commission. On the other hand, if the executive and legislative branch would ... [make] their decision openly and informed by contemporary views ... the Court would be much more willing to defer to their judgment.

120 426 U.S. 668 (1976). 
required approval of zoning variances by a fifty-five percent vote in a referendum. The majority, citing Justice Black's description of the referendum as "a classic demonstration of 'devotion to democracy," "421 concluded that such a referendum was not an unconstitutional delegation of legislative responsibility. ${ }^{422}$ Although the Court recognized the possibility of unfair results from such a system, the majority said that a landowner who suffered an arbitrary disposition of his variance request could vindicate his rights adequately by seeking administrative relief. ${ }^{423}$

Justice Stevens, dissenting, invoked a "proper decisionmaker" argument similar to that in his majority opinion in Mow Sun Wong and found that the referendum procedure violated the due process clause of the fourteenth amendment. ${ }^{424}$ The Justice quoted extensively from the Ohio Supreme Court's decision striking down the procedure. The language of the Ohio court is strikingly similar to the due process of lawmaking terminology Justice Stevens employed in Mow Sun Wong:

Due process of law requires that procedures for the exercise of municipal power be structured such that fundamental choices among competing municipal policies are resolved by a responsible organ of government. . . . [and] that fundamental policy choices underlying the exercise of that power are articulated by some responsible organ of municipal government. ${ }^{425}$

Justice Stevens agreed with the Ohio court that a plebiscite was not a "responsible" decisionmaking body. The referendum provision set no standards for the voters to use in evaluating the merits of a landowner's request for a variance. Moreover, the Justice observed, "most of the voters would be indifferent and uninformed about the wisdom of building apartments rather than a warehouse." ${ }^{226} \mathrm{He}$ found the majority's assertion that any unfairness in the procedure could be ameliorated through "administrative relief" to be an inadequate substitute for an initially fair and rational decisionmaking process. ${ }^{427}$

121 Id. at 679 (quoting James v. Valtierra, 402 U.S. 137, 141 (1971)).

12 Respondents argued, as the Ohio Supreme Court had held, that the delegation was impermissible because "the voters were given no standards to guide their decision." 424 U.S. at 675 .

123. at 679 n.13.

121 Justice Stevens employed due process analysis because "the opportunity to apply for an amendment" is a protected property interest. Id. at 682 (Stevens, J., dissenting).

${ }^{123}$ Id. at 688 (quoting 41 Ohio St. 2 d 187, 196, 324 N.E.2d 740, 746 (1975)).

4226 U.S. at 694.

${ }^{27}$ Id. $\mathrm{n} .16$ ("A procedure in one case does not become constitutionally sufficient because some other procedure might be available in some other case."). 
Justice Stevens further argued that because of the nature of the decisions being made-determinations of individual property rights-the referendum procedure was particularly inappropriate: the general electorate is incapable of collecting the information required to make such determinations of fact and policy on a rational basis. ${ }^{428}$ In sum, the Justice stated, "popular vote is not an acceptable method of adjudicating the rights of individual litigants." 429 Since the Justice characterized the challenged procedure in Eastlake as "administrative," the due process protection required was that of a fair hearing. He made clear, however, that whether the procedure in Eastlake was characterized as administrative or legislative, the type of dispute submitted to the referendum demanded that "interested parties be given a reasonable opportunity to have their dispute resolved on the merits by reference to articulable rules." 430

\section{The Scope of Due Process of Lawmaking}

It is not clear how extensively Justice Stevens would have the courts delve into the rationality of the lawmaking processes of government. The scrutiny of actual legislative purpose in Goldfarb and Craig suggests a use of this analysis as an element of equal protection doctrine. ${ }^{431}$ But Justice Stevens's insistence in Delaware Tribal that a statutory classification is constitutionally suspect if it was an "accident"-an insistence that led to his dissent in the case-seems to go much farther. Instead of merely serving to alert the courts to laws of dubious validity, the due process of lawmaking doctrine as invoked in Delaware Tribal seems to demand a general rationality in the decisionmaking process itself. Finally, the Justice's analysis of delegated lawmaking responsibilities in Mow Sun Wong and Eastlake suggests an expansive judicial role in determining that certain bodies-because of lack of interest, information, or expertise-are unlikely to act rationally, and hence are not competent lawmakers. The two aspects of Justice Stevens's analysis of the processes of governmental decisionmaking-inquiring into actual legislative purpose and requiring that certain decisions be made by

123 Id. at 693-94.

12 Id. at 693 .

tso Id. at 692-93.

131 The requirement of a clearly articulated legislative intent in cases involving a deprivation of some protected interest, however, is not novel, see, e.g., Kent v. Dulles, 357 U.S. 116, 129,130 (1958), and although the search for "true" governmental purpose is arguably new, there are at least indications of such a search in some earlier cases. See note 354 supra. See also L. TriBE, supra note 12, § 16-30. 
an appropriate decisionmaker-thus form a general model for judicial review of legislative, administrative, or quasi-judicial enactments. Justice Stevens seems to demand that "laws, unlike naked commands, be explained to those they touch," 432 and that lawmaking bodies must be accountable for the decisions they make. That is, the Justice will not respect political decisions if the decisionmaker has not articulated the reasons for the decision and considered its political consequences.

A strict requirement of rationality in all aspects of the legislative process, however, raises difficult problems for a political system based upon a concept of representative democracy. There is no reason to presume that democratic decisionmaking can always be "rational" as demanded by Justice Stevens. Legislators, administrators, and voters may sometimes behave as carefully calculating policymakers, weighing the advantages and disadvantages of a given proposal and carefully tailoring the resulting scheme to accomplish the most good with the least cost. Often, however, they will weigh interest group against interest group, principle against expediency, and national interests against the desires of their constituencies. ${ }^{433} \mathrm{~A}$ wide-ranging judicial scrutiny of legislating processes entails the difficult task of ascertaining the decisionmakers' subjective thought processes and motives. ${ }^{434}$ Evaluation of the rationality of legislators, as opposed to scrutiny of the rationality of the results of legislative decisions, should be the function of the electorate rather than the courts..$^{435}$

But Justice Stevens has generally applied the due process of lawmaking analysis in justifiable circumstances. First, there is a strong argument for ascertaining "true" legislative purpose as an adjunct to equal protection scrutiny. While the rationality of individual legislators is properly subject to review by the voters, the courts should not countenance irrational or arbitrary laws that impinge on significant interests of classes of individuals in need of

132 Tribe, From Environmental Foundations to Constitutional Structures: Learning from Nature's Future, 84 YALE L.J. 545, 554 (1975).

as See Village of Arlington Heights v. Metropolitan Housing Dev. Corp., 429 U.S. 252, 265 (1977).

141 Inquiry into the motives of legislators also necessarily involves the subjective notions and prejudices of the judge, which may affect the judge's assessment of legislative motive.

iss The point is that evaluation of the quality of performance of the task of lawmaking should be made by the individual(s) from whom the decisionmaking authority derives and to whom the decisionmaker is accountable. Thus, agencies operating pursuant to authority delegated by Congress or the President should be evaluated by the source of their respective delegated powers. 
special protection. ${ }^{436}$ Second, when a decisionmaking body is not accountable for its decisions, as in Mow Sun Wong, the courts may justifiably demand evidence of a rational decisionmaking process. Finally, when a governmental body - whether a legislature, administrative agency, or the electorate by referendum-makes quasijudicial determinations of the particular interests of individuals, as in Delaware Tribal or Eastlake, ${ }^{437}$ judicial deference to the "legislative" process is a less compelling consideration. In one respect, Justice Stevens's use of the due process of lawmaking doctrine reflects a reluctance to usurp the lawmaking function of legislative and administrative bodies. By "remanding" a challenged provision to the responsible decisionmaking body, Justice Stevens acknowledges the proper lawmaking functions of the executive and legislative branches of government while preserving the right of the governed to be free from arbitrary or uninformed decisions and invidious, though arguably justifiable, classifications..$^{438}$

\section{Conclusion}

Perhaps the most striking aspect of Justice Stevens's constitutional opinions is their novelty. ${ }^{439}$ The Court's newest member is often willing to depart sharply from the courses taken by his fellow Justices and to reformulate judge-made rules of constitutional law in a manner closer to his perception of the fundamental principles of the Constitution. Novelty in judicial decisionmaking can be dangerously unsettling in a system that derives its continuity from past decisions. By its very nature, however, constitutional law, to a far greater degree than other areas of the law, requires rethinking by each generation of judges. A mistaken or archaic interpretation of a statute has ready redress in the legislature; interpretation of the Constitution has no such institutional safeguard. Moreover, strict

134 See Village of Arlington Heights v. Metropolitan Housing Dev. Corp., 429 U.S. 252, 265 (1977).

${ }_{437}$ Delaware Tribal, to be sure, involved legislation, but that "the legislative action under review is the culmination of a quasi-judicial proceeding brought on behalf of the entire class distinguishes this legislation from policy decisions of general applicability." 430 U.S. at 97 n.8 (Stevens, J., dissenting). The characterization of the Indian Claims Commission as at least a quasi-adjudicative body seems correct. See 25 U.S.C. $\S \S 70-70 \mathrm{v}-2$ (1976).

133 That the notion of "remand to the legislature" is inherent in the application of the due process of lawmaking doctrine has been noted elsewhere. L. TRIBE, supra note 12, § 17-2, at 1142-43; Sager, supra note 355, at 1417 . The procedure has been urged by a number of commentators in the past. See L. TRIBE, supra note 12, § 17-2, at 1143 n.12 (citing authorities).

43 See, e.g., Wolman v. Walter, 433 U.S. 229 (1978) (Stevens, J., concurring in part, dissenting in part); Young v. American Mini Theatres, Inc., 427 U.S. 50 (1976) (Stevens, J.); Hampton v. Mow Sun Wong, 426 U.S. 88 (1976) (Stevens, J.). 
application of stare decisis would elevate judicial pronouncements to the level of constitutional provisions. If the purpose of judicial interpretation is to enforce the elusive content of the Constitution, the text itself, not merely the existing judicial gloss on that language, is the proper starting point for the Court's analysis. ${ }^{400}$ When existing judge-made rules cease to resolve new disputes in a way consistent with the Constitution, those rules should not be dispositive. ${ }^{441}$

This conception of the judge's role in constitutional decisionmaking has influenced Justice Stevens's analysis. For example, in his fourth amendment opinions-Barlow's, Tyler, and Stanford Daily-the Justice recognized that controlling precedents developed in response to particular circumstances may be inappropriate in other contexts. His rejection of the warrant as the touchstone of "reasonable" searches and seizures in Barlow's was based not on a belief that the warrant-preference of his colleagues failed to produce a fair and protective result in that case, but upon a fear that the majority's distortion of the historical purpose of the amendment would ultimately dilute its protective role. Similarly, in Stanford Daily the Justice refused to apply a settled notion of probable cause in a context that involved individual interests outside the scope of the precedents applied by the Court. The Justice has also departed from recent Court precedent in his procedural due process opinions by refusing to require a statutory or constitutional entitlement as the source of protected liberty interests. Justice Stevens's opinions in these cases were a product less of his personal policy preferences than his conviction that the particular rule applied by the Court failed to reflect the principles it ostensibly serves.

Justice Stevens has adopted approaches to constitutional problems that emphasize fundamental principles and goals, but not strict constitutional rules. Often the Justice utilizes a balancing approach as a technique for applying these principles. Such an approach to constitutional adjudication, however, can easily obscure the underlying "fundamental" principles. The most notable shortcoming of his balancing process is his failure to articulate why he finds some interests more important than others. The Justice's first amendment and equal protection decisions have a result-oriented

“1 See Graves v. New York, 306 U.S. 466, 491 (1939) (Frankfurter, J., dissenting) ("The ultimate touchstone of constitutionality is the Constitution itself, and not what we have said about it."); E. Levi, An Introduction to Legal Reasoning 57-60 (1949).

"1' Justice Cardozo, attacking the "tyranny of labels" in constitutional theory, criticized the tendency of courts to apply a general rule, that was "wrought under the pressures of particular situations," in another situation where it has little relation to the reasons that brought it into existence. Snyder v. Massachusetts, 291 U.S. 97, 114 (1934). 
quality that often seems to reflect his own notion of common sense, rather than a principled basis for assigning priority to one interest over another. The Justice's decisions in Pacifica and Mini Theatres, for instance, provide only meager guidance to lower courts and legislatures that rely on Supreme Court precedent to explicate the limits of constitutionally permissible lawmaking.

One recurring, and often dispositive, factor in Justice Stevens's constitutional analysis is the nature of the confrontation between the individual and the state. In situations he views as far from the central concerns of the Constitution he hesitates to disturb the status quo. This theme recurs in his procedural due process, first amendment, equal protection, and fourth amendment opinions: where "routine" governmental activities are concerned, Justice Stevens is willing to defer to legislative or executive judgments. Thus, when faced with legislatively specified procedures for health and safety searches in Barlow's, utility terminations in Memphis Light, employment dismissals in Bishop, or zoning regulation of theaters showing sexually explicit films in Mini Theatres, the Justice respected legislative decisions. But when he has addressed individ$\mathrm{ual} / \mathrm{state}$ confrontations of a more extraordinary nature, such as the deprivations of liberty in Meachum and Moody or the search of innocent third parties in Stanford Daily, he has assigned a greater role to the federal court in enforcing constitutional protections.

Justice Stevens's use of balancing does not indicate that he has succumbed to the "dilemma of the realist tradition." ${ }_{442}$ Although Justice Stevens's opinions do reflect a recognition of the irreducible element of "legislating" 443 inherent in Supreme Court decisionmaking, he also acknowledges the need to refer constantly to the antecedent legislating of the Framers. It is not merely precedential, political, and institutional concerns that limit the Court's discretion, ${ }^{444}$ but also the presence of a text not entirely devoid of substantive meaning. To the extent that the Court can shape the law and thus serve competing social interests, Justice Stevens appears to recognize that it must do so with primary attention to the

142 Linde, Judges, Critics, and the Realist Tradition, 82 YALE L.J. 227, 252 (1972) ("Realism sees the norms as the product of the institution. But the institution must, by the logic of its own legitimacy, see its action as the product of the norm. However useful it is to recognize that the law emerges from what judges do, it does not serve well as a source of the premises for what judges should do.").

is See generally P. KurLand, Politics, the Constitution, and the WarRen Court 17374 (1970).

i1 But see id. at 175-81; A. Bicked, The Supreme Court and the Idea of Progress 81100 (1970). 
balances already made in the Constitution. ${ }^{45}$

Although Justice Stevens recognizes the responsibility of coordinate branches of government to uphold the Constitution, to the extent that nonjudicial bodies engage in a balancing of interests in their decisionmaking processes, the Justice, with the rest of the Court, requires that they not act irrationally or arbitrarily. But Justice Stevens-unlike his fellow Justices-also demands that legislative and administrative lawmaking be the result of a demonstrably rational process by a competent decisionmaker. This is the focus of the Justice's due process of lawmaking analysis. The decisions of governmental bodies that implicate substantive constitutional rights must rest upon legitimate, articulated purposes. Thus, although Justice Stevens often seems to acquiesce in the decisions of other institutions ostensibly more responsive to the people than the courts, he does not fail to provide protection against the potential irrationality of those bodies.

Justice Stevens has adopted a constitutional approach that invites criticism. His penchant for balancing of interests often overshadows the principles underlying his opinions. His departure from prior judicial interpretations of constitutional guarantees is often uncritical and terse. He fails to develop fully the potential analytical problems in his constitutional interpretations unless they are expressly presented by the case. Yet these shortcomings pale once the Justice's direction becomes clear. His place on the Court has been to rethink doctrine and to challenge old assumptions as the Court applies them to new situations. His opinions have been attempts to preserve what is valuable in existing rules while formulating broad doctrines capable of responding to the demands of modern society. That Justice Stevens's jurisprudence is open to criticism should not overshadow the value of his innovative approach to the Constitution.

Jonathan C. Carlson Alan D. Smith

" 4 Determining the scope and meaning of the decisions made at the Founding is " $a$ different responsibility from that of explaining why society would benefit from a judicial change in the common law." Linde, supra note 441, at 254. 